\title{
11. \\ VLADAN DESNICA I \\ MAGAZIN SJEVERNE DALMACIJE: \\ KNJIŽEVNIK I (NE)MOĆ TRADICIJE
}

\section{Drago Roksandić}

UDK: 050.8(497.581=163.41)“1932/35“

Izvorni znanstveni članak

Sažetak: Vladan Desnica u svojim kasnijim godinama nikada ništa nije javno rekao o $\mathrm{Ma}$ gazinu Sjeverne Dalmacije. Analitičkim propitivanjem velikim dijelom prvi put korištenih izvora, ovaj rad pokušava historiografski odgovoriti na sljedeća pitanja: Kakve su bile egzistencijalne i profesionalne te, istovremeno, artističke orijentacije Vladana Desnice u godinama nakon završetka studija prava u Zagrebu 1930. godine, tj. nakon povratka u Split? Je li Magazin Sjeverne Dalmacije u to doba bio njegov privremeni ili dugoročni interes? Zašto mu je pritom uopće bila potrebna suradnja s Privredno-kulturnom maticom za Sjevernu Dalmaciju i njezinim Glasom? Što su Matica i Glas bili u to vrijeme u Dalmaciji i kakva su sve bila očekivanja Matičinih ključnih aktera od Desnice? Što se postupno mijenjalo u Matici i Glasu nakon ustoličenja dr. Irineja Đorđevića za dalmatinskog vladiku 1931. godine? Je li Desnica situacijski prilagođavao izvorno najavljenu koncepciju časopisa u svojoj uredničkoj praksi od 1932. do 1935. godine? Koje svoje radove je objavio u Magazinu Sjeverne Dalmacije? Što su objavili njegovi otac dr. Uroša Desnice i stric Boško Desnica? Zašto se pojavila "Jedna izjava iz Sjeverne Dalmacije“? Kakav je bio Odgovor na „Jednu izjavu iz Sjeverne Dalmacije"? Koji je bio smisao umreženih sporova u vezi s Magazinom Sjeverne Dalmacije? Je li moguće rekonstruirati njihovu kronologiju? Koliko je i kako Vladan Desnica bio u njima involviran? Što je na koncu Magazin Sjeverne Dalmacije bio za Vladana Desnicu?

Ključne riječi: Vladan Desnica, Magazin Sjeverne Dalmacije, 1932. - 1935., Split, društveni i kulturni razvoj, historiografija, književnost, interkulturalizam

ladan Desnica u svojim kasnijim godinama nikada ništa nije javno rekao o Magazinu Sjeverne Dalmacije. ${ }^{1}$ U njegovoj osobnoj ostavštini - koliko nam je poznato - malo je tragova ovog časopisa. ${ }^{2}$ Djelomično sačuvana prepiska sa stricem Boškom vjerojatno

1 Dušan Marinković, „Biografija Vladana Desnice“, Hotimično iskustvo: diskurzivna proza Vladana Desnice. Knjiga druga (prir. Dušan Marinković), Zagreb 2006., 227-229. U nastavku članka ćemo umjesto punog naziva časopisa Magazin Sjeverne Dalmacije koristiti kraticu MSD (osim u citatima).

2 Osobna ostavština Vladana Desnice. Srdačno zahvaljujem dr. sc. Urošu Desnici, piščevu sinu, što mi je omogućio korištenje ove ostavštine. Umjesto punog naziva Osobna ostavština Vladana Desnice u članku će se koristiti kratica OOVD. 
je najvažniji. ${ }^{3}$ Ostalo je i nešto korespondencije sa suradnicima $M S D$ pa i s drugima koji su se oglašavali u vezi s časopisom. Ima nešto objavljenih prikaza i ocjena, kritika, različitih posebnih otisaka itd. Nije moguće reći da zrelom Desnici nije bilo stalo do materijalnih svjedočastva o $M S D$. Sačuvani tragovi tim su važniji što je poznato da se pisac - prema vlastitom iskazu - često vraćao svojim ranijim književnim temama i pritom uništavao suvišnu rukopisnu dokumentaciju. ${ }^{4}$ Što će ostati sačuvano u njegovu posjedu, dakako, nije ovisilo samo o njemu. Dovoljno je podsjetiti se da je u Zadru 1943. preživio bombardiranje te da su Kula u Islamu Grčkom i obiteljska kuća u Splitu bili bombardirani 1944. godine itd. Ako pritom, srećom, nisu stradali on i njegova obitelj, svaki je put stradavala imovina. ${ }^{5}$

Budući da nije moguće istraživati $M S D$ neovisno o šibenskoj Privredno-kulturnoj matici za Sjevernu Dalmaciju (1928. - 1936.), dragocjeno bi bilo uspjeti pronaći Matičin arhiv. Zasad nam nije bilo moguće ući u njegov trag. Nije isključeno da negdje postoji. U Nacionalnoj i sveučilišnoj knjižnici u Zagrebu sačuvani su srećom gotovo svi brojevi Matičina Glasa (1929. - 1936.), koji je većim dijelom navedenog razdoblja izlazio tjedno, također u Šibeniku, s tekstovima na ćirilici i latinici. ${ }^{6}$ To je također važan izvor. Odnedavno raspolažemo s tri izvora koji izravno svjedoče o jezgri sporova u Matici od 1932. do 1936. godine, koji su se reflektirali na Vladanu Desnici i $M S D$ ili u kojima je i mladi Desnica bio akter. ${ }^{7}$

Spomenuti izvori omogućuju donekle drugačiji istraživački pristup mladom Desnici i kvalitativno različit pristup $M S D$ kao kulturnom i političkom fenomenu nego što je to dosad obično bio slučaj. ${ }^{8}$ Oni potiču i na novo čitanje svih radova objavljenih u dva sveska časopisa.

Među istraživačima piščeva opusa godinama, sve do nedavno, nije bilo izraženijeg interesa za Vladana Desnicu i $M S D$. Ako ga je i bilo, prevladavao je pristup koji je zagovarao Stanko Korać, npr. u beogradskoj Književnoj reči 1987. godine:

Desničin Magazin sjeverne Dalmacije bio je veoma kratkog vijeka pa nije mogao okupiti širi krug saradnika, a potpuno su izostali vodeći pisci. Ovaj časopis je značajan u prvom redu po tome što je u njemu nastupio Vladan Desnica, pjesmama, esejima i pripovjetkom. (...) Program Desničinog časopisa objavljen je u prvoj svesci za 1934. godinu. ${ }^{9}$

3 Sačuvanu prepisku s Boškom najvećim dijelom čine pisma koja je Boško pisao Vladanu. Vladanova pisma Bošku možda su sačuvana u osobnoj ostavštini Boška Desnice, koju nisam imao prilike istraživati.

4 Jevto M. Milović, „Razgovor s Vladanom Desnicom o umjetničkom stvaranju“, Hotimično iskustvo. Knjiga druga, 116.

5 Drago RoKsandić, „Ratni dani Vladana Desnice“, Intelektualci i rat 1939. - 1947. Zbornik radova s mecunarodnog skupa Desničini susreti 2012. (ur. Drago Roksandić i Ivana Cvijović Javorina), sv. 2, Zagreb 2013., 536, 540-541.

6 U nastavku članka ćemo umjesto punog naziva Glas Privredno-kulturne Matice za Sjevernu Dalmaciju koristiti skraćeni oblik Glas.

7 „Jedna izjava iz Sjeverne Dalmacije“, Novo doba (Split), br. 217, 16. 9. 1934., 11-12 [!]; Odgovor na „Jednu izjavu iz Sjeverne Dalmacije“, Uredništvo „Glasa“ Privredno-kulturne Matice, Beograd 1934., 44 str. (ćir.); Severna Dalmacija nekad i sad. Odlučna reč u kritičnom času, Glavna zadruga za narodno prosvećivanje, Beograd 1939., 142 str. + karta (ćir.); Pavle Zelić, „Odgovor na 'Priopćeno'“, Novo doba (Split), br. 227, 27. 9. 1934., 6.

8 Magazin Sjeverne Dalmacije (ur. Vladan Desnica), 1/1934., Split 1934., 160 str. (ćir. i lat.); 2/1935., Split 1935., 178 str. (ćir. i lat.).

9 Stanko Korać, „Književna saradnja Vladana Desnice u 'Magazinu sjeverne Dalmacije'“, Književna reč (Beograd), 14/1985., br. 263, 16-18 (ćir.). Korać pogrešno piše naslov časopisa - nije Magazin sjeverne Dalmacije, nego Magazin Sjeverne Dalmacije. Razlika je pojmovne naravi. 
Autor ga je citirao u cijelosti, smatrajući da to zaslužuje jer „sadrži stavove koje možemo i danas smatrati aktuelnim “. ${ }^{10}$ Inače, u analizu programa uopće nije ulazio. Percipirajući MSD prvenstveno kao fenomen književne časopisne produkcije Srba u Hrvatskoj, Korać ga je smjestio u niz koji započinje Slaveno-serbskim magazinom Vukovarca Zaharija Orfelina (1768.), traje Srpsko-dalmatinskim almanahom/magazinom Šibenčanina Teodora (Božidara) Petranovića i njegovih nastavljača (1836. - 1873.), zakratko se obnavlja splitskim Desničinim časopisom i potom, iznova zakratko, njegovim (Koraćevim) zagrebačkim Novim ljetopisom (1971. - 1972.). ${ }^{11}$ Takvim pristupom zapravo nije ni bilo moguće nešto vrijedno reći o Vladanu Desnici u to doba, a da ne spominjemo $M S D$. Uvelike je pogriješio u vrednovanju Desničina splitskog stvaralaštva. U jednome, ključnom vidu, iznevjerio je čak smisao čitava piščeva opusa:

Desnica se, dakle, pojavljuje pred nama u tom međuratnom periodu kao formiran pisac, a formirao se na srpskoj književnoj i nacionalnoj podlozi, s tim što je njegovo formiranje bogaćeno italijanskim, grčkim, rimskim i ruskim uticajima. Pažljivim čitanjem njegovih kasnijih djela otkrivamo podlogu koju smo istakli i uticaje koje smo naveli. ${ }^{12}$

Koraćev je Desnica bez hrvatske „podloge“ pa i bez hrvatskih „uticaja“! Da je Koraćev pristup bio drugačiji, na površinu bi isplivale i srpske i hrvatske „podloge“ $i$,uticaji“ $i$ to ne samo u slučaju Desnice nego i drugih suradnika u MSD. Pokušat ćemo to i dokazati.

Bitno je drugačiji, teorijski artikuliran i književnopovijesno kontekstualiziran, ali - nažalost - analitički nedovoljno utemeljen pristup koji je 2006. ponudio Dušan Marinković u „Biografiji Vladana Desnice“.13 Suglasni smo s dva ključna autorova stajališta.

Prvo, premda je Desnica bio najavio pokretanje časopisa koji će slijediti tradiciju Srpsko-dalmatinskog magazina dr. Božidara Petranovića i njegovih nastavljača, kao što i autor ističe, nije propustio naglasiti da će časopis reflektirati promijenjenu povijesnu i kulturnu stvarnost. Toga se kasnije dosljedno i držao:

U Magazinu je okupio zainteresirane intelektualce s područja Dalmacije koji su se naučno bavili problematikom kulturne i opće historije Dalmacije, što je i bio zadatak i namjena novopokrenute publikacije. Magazin je svoju kulturnu orijentaciju legitimirao i okupljenim autorima i štampanjem tekstova na ćirilici i latinici. ${ }^{14}$

Iako to autor izrijekom nije rekao, $M S D$ je u oba svoja sveska bio interkulturni fenomen sa subregionalnim, sjevernodalmatinskim žarištem. Time se razlikovao od Petranovićeva Magazina. Bitno je bio različit u odnosu na Matičine intencije, koje su u Glasu doduše bile tiskane na oba pisma, ali je mentalni sklop u kojem su bile oblikovane u ovo doba bio sasvim različit od Desničinog. ${ }^{15}$ Nastojat ćemo i to dokazati.

\footnotetext{
Isto, 16.

1 Isto.

12 Isto, 18.

13 D. Marinković, „Biografija Vladana Desnice“, 227-229.

14 Isto, 228.

15 U vrijeme kada je Vladan Desnica slušao brojne Matičine prigovore na račun svoje koncepcije MSD, Glas je ovako definirao „Jugoslavenski Vidovdan“: „Jugoslavenski Vidovdan, kao i srpski, kult je i služba carstvu nebesnom, ali on
} 
Inače, o dr. Petranoviću i Srpsko-dalmatinskom magazinu u MSD ništa nije bilo objavljeno ni u prvom ni u drugom svesku. ${ }^{16}$ Koliko god ga Desnica mogao cijeniti, Petranović je za njega prije svega bio čovjek minule epohe. Pravnik, političar, pisac, publicist pa i znanstvenik u 19. stoljeću mogli su koegzistirati u jednoj osobi, stvarati i afirmirati jake osobnosti kao što je Petranović nesumnjivo bio. Desnici je to bilo strano. Njihove publikacije su se morale uvelike razlikovati, koliko god Desničina mogla tradicijski referirati na Petranovićevu. ${ }^{17}$

Drugo, prihvaćamo autorovu ocjenu mladog Desnice - doduše, ponešto anticipativno izrečenu u „Biografiji“ - imajući na umu da je Desnica prije početka rada na MSD bio objavio samo esej o Dujmu Peniću. ${ }^{18}$ Prihvatljiva nam je kao ocjena Desničinih radova tiskanih u njegovu časopisu:

Već po prvim objavljenim tekstovima može se konstatirati, bez obzira u kojem se žanru izražavao, da Vladan Desnica još kao mlad stvaralac teži što cjelovitijem i što kompleksnijem sagledavanju teme koju nastoji oblikovati, da ne teži nikakvim jezičnim, stilskim ili kakvim drugim efektima, da želi pisati radove „od trajnijeg značaja“, kao što će sam reći kasnije. Autor kojeg ne vodi tema i tekst, nego više-manje jasna vizija onoga što želi reći. Također: individualnost koja teme o kojima govori vidi i kao implicitnu/i polemiku/dijalog $s$ uvriježenim stajalištima drugih. ${ }^{19}$

Ipak, raspoloživi izvori čine mogućim ustvrditi da su nedovoljno jasne poneke autorove formulacije o izdavačkoj orijentaciji Privredno-kulturne Matice za Sjevernu Dalmaciju

mora biti sinteza vječnog i vremenskog, harmonija nebeskog i zemaljskog; on mora da bude čuvar kosovske vjere, čuvar narodnog obraza i ponosa, ali i neimar naše nacionalne, rasne kulture koja treba nama, ali treba i posrnulom zapadnom čovječanstvu, od koga jedva šta dobro imamo da naučimo.“ ([Stevo] P[ROSTRAN], „Naš novi vidovdanski zavjet“, Glas, br. 154, 22. 6. 1933., 1.) Vladika Irinej u svojim propovijedima zastupao je u isto to vrijeme „pasivnu etnokonfesionalnu toleranciju“: „No vi živite, hvala Bogu, u istoj državnoj kući sa braćom drugih plemenskih imena i drugih vera. Vladika Vaš vam poručuje da poštujete njihova imena kao i svoja, njihovu veru kao i svoju. Ako oni vas ismevaju ili pogrdnim imenima nazivaju, - vi to ni jedno njima ne činite; ako oni ruže i preziru veru i Crkvu vašu, - vi njihovu nemojte ni ružiti ni prezirati; svojim najboljim rečima odgovarajte na najružnije reči njihove, ako bi vam - ne daj Bože - upućene bile; svojim najboljim delima se odazovite i na najteže uvrede (...)“ („Junaci mira (Iz božićne poslanice episkopa dalm[atinskog] g. Dra I. Đorđevića)“, Glas, br. 176-177, 4. 1. 1934., 1 (ćir.).)

16 Vladan Desnica je ujesen 1932. godine bio zamolio - slijedeći sugestije iz Matice - šibenskog odvjetnika i političara dr. Nikolu Subotića da napiše rad o dr. Božidaru Petranoviću i Srpsko-dalmatinskom magazinu, a ovaj mu je 1. 12. 1932. odgovorio: „O Petranoviću ja nisam nikad držao predavanje. Ja sam samo, kao predsednik (nečitko - D.R.), održao jedno slovo nad njegovim grobom, koji je u ovdešenjem groblju. Predavanje je održao prof. g. Marko Triva, koji je sada na službi na Prosv[etnom] odseku u Splitu. On je, možda, upotrebio, jer ne smem kazati, da je iskoristio razgovore koje smo nas dvojica imali o Petranoviću. Mislim ali ne znam tačno, da je Triva to predavanje prikazao kao svoju diplomsku dizertaciju. U njoj ima i praznina. Obratite se, dakle, g. Trivi, a ja bih mogao dati koji manji prilog o Petranoviću." (Dr. Nikola Subotić - Vladanu Desnici, Šibenik, 1. 12. 1932. (ćir.), OOVD, kut. Prepiska do 1945. I.) Nema traga bilo kakvu Desničinu pokušaju da s Markom Trivom dogovori takav prilog. Vladan Desnica je ljeta 1934. ponovno molio dr. Subotića da piše o dr. Petranoviću, a ovaj mu je odgovorio iz Šibenika, 10. kolovoza 1934.: „Dijeleći Vaše mišljenje, da treba izdignuti iz nezasluženog zaborava Dra Petranovića, jer bih mogao uzeti na sebe da napišem jednu radnju o svemu. Ta bi, razume se, morala biti nešto duža." (Dr. Nikola Subotić - Vladanu Desnici, Šibenik, 8. 8. 1934. (ćir.), OOVD, kut. Prepiska do 1945. I.) Kasnije se ni dr. Subotić ni rad o dr. Petranoviću za $M S D$ više ne spominju.

17 U ovom radu neće biti moguće ući u inače nužnu usporedbu Srpsko-dalmatinskog magazina i MSD.

18 Vidjeti: Vladan Desnica, „Izložba vajara Dujma Penića u Splitu“, Život i rad (Beograd), god. VI, knj. 17, sv. 99, Beograd 1933., 1211-1213 (ćir.). Isti tekst, ali pod naslovom „Kipar Dujam Penić. (Prigodom izložbe u Splitu)“ objavljen je u splitskom Novom dobu, br. 241, 14. 10. 1933., 9. 
i njezina Glasa, o Desničinu statusu u planiranoj publikaciji, a donekle i o naravi kritika i konflikata nakon objavljivanja oba broja časopisa. Pokušat ćemo nešto više reći o tome polazeći od hipoteze o Desničinu MSD kao o interkulturnom i dijaloškom glasilu u dalmatinskoj subregiji, subregiji ne(s)poznate prošlosti i neizvjesne budućnosti i to u kriznom trenutku njezine povijesti.

Analitičkom propitivanjem velikim dijelom prvi put korištenih izvora, pokušat ćemo ovim radom historiografski odgovoriti na sljedeća pitanja: Kakve su bile egzistencijalne i profesionalne te, istovremeno, artističke orijentacije Vladana Desnice u godinama nakon završetka studija prava u Zagrebu 1930. godine, tj. nakon povratka u Split? Je li $M S D$ u to doba bio njegov privremeni ili dugoročni interes? Zašto mu je pritom uopće bila potrebna suradnja s Privredno-kulturnom maticom za Sjevernu Dalmaciju i njezinim Glasom? Što su Matica i Glas u to vrijeme u Dalmaciji bili i kakva su sve bila očekivanja ključnih aktera u Matici od Desnice? Što se postupno mijenjalo u Matici i Glasu nakon ustoličenja dr. Irineja Đorđevića za vladiku dalmatinskog 1931. godine? Je li Desnica situacijski prilagođavao svoju izvorno najavljenu koncepciju časopisa u uredničkoj praksi od 1932. do 1935. godine? Kakva je bila autorska suradnja Vladana Desnice u MSD? Kakve su bile autorske suradnje njegova oca dr. Uroša Desnice i strica Boška Desnice? Zašto se pojavila „Jedna izjava iz Sjeverne Dalmacije“?20 Kakav je bio Odgovor na "Jednu izjavu iz Sjeverne Dalmacije"? ${ }^{21}$ Koji je bio smisao umreženih sporova u vezi s $M S D$ ? Je li moguće rekonstruirati njihovu kronologiju? Koliko je i kako Vladan Desnica bio u njima involviran? Što je na koncu MSD bio za Vladana Desnicu? Međutim i ovaj će rad više pitanja otvoriti nego što će ih istraživački moći zaključiti pa su i ove uvodno navedene kritičke opaske dijaloške naravi, pledoaje za daljnju raspravu.

\section{Splitske nedoumice mladog Desnice}

Desnica je studirao pravo u Zagrebu od 11. listopada 1924. do 28. lipnja 1930., dakle skoro punih šest godina. ${ }^{22} \mathrm{U}$ međuvremenu je školske godine 1927./1928. proveo dva semestra u Parizu i vratio se k roditeljima, u splitsku Sinjsku 7, zadržavši se u međuvremenu kraće vrijeme u Italiji. ${ }^{23}$ Studij je završio u vrijeme Svjetske krize, ali ga globalne neizvjesnosti očito nisu potakle da se potrudi doktorirati i da slijedi primjer svog oca, koji je bio stekao doktorat prava u Beču, u epohi Jahrhundertwende. Odvjetnička karijera u očevu splitskom uredu izgleda da mu se nije činila osobno poželjnim i održivim životnim izbo-

\footnotetext{
Vidjeti bilj. 7.

21 Uredništvo „Glasa“ Privredno-kulturne matice, Beograd 1934. (ćir.). Vidjeti bilj. 7.

22 D. Marinković, „Biografija Vladana Desnice“, 224-225.

23 U Desničinu kadrovskom „Opštem upitniku“ od 15. studenog 1947. godine stoji u rubrici 23.: „Boravak u inostranstvu /vreme, mesto i cilj boravka/: 1913, 1914 kratka put[ovanja] u Italiju uz roditelje; 1919 u Italiji uz oca internirca; 1927 u Parizu radi studija; 1928 kratko put[ovanje]u Italiju radi odmora..." (OOVD, kut. Služba i mirovina II.)

24 U kasno ljeto 1935. javio mu se stric Boško na temu „nezadovoljstva radi promašenog životnog puta“: „Što se tiče tvog nezadovoljstva radi promašenog životnog puta, mogu da ti kažem da se kod tebe ponavlja moj slučaj: i mene je za deset godina grizlo i trovalo isto nezadovoljstvo i ja sam isto kao i ti krivio i optuživao svoga ćaću. Razlika je samo u tome što ti to činiš sa nešto više prava neg ja, jer su tvoje sposobnosti daleko veće i daleko jače prononsirane nego
} 


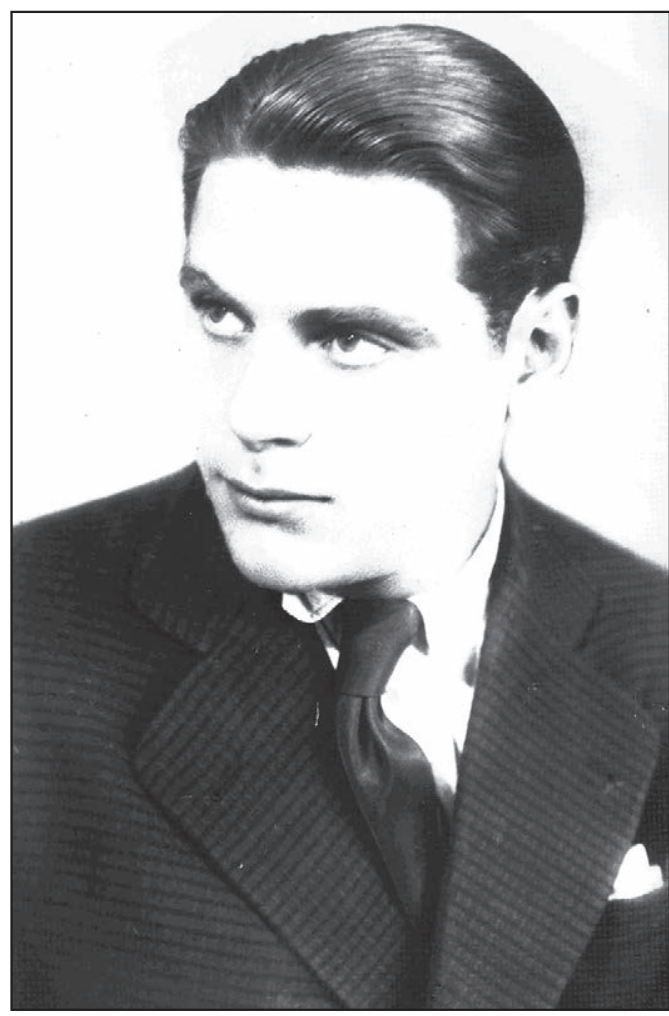

Sl. 1. Vladan Desnica u Splitu 1932. (foto: Vladimir Sinobad, Split) rom. ${ }^{24}$ Međutim, nije mogao birati, tim više što je morao odslužiti i vojni rok. Od 1. srpnja 1930. do 4. travnja 1933. bio je koncipijent u odvjetničkom uredu dr. Uroša Desnice. U međuvremenu, od 31. kolovoza do 28 . studenog 1932., bio je i na odsluženju vojnog roka. Prvog travnja 1933. prešao je u državnu službu, dobivši mjesto pripravnika VIII. grupe u splitskome Državnom pravobranioštvu. Pristav VIII. grupe $\mathrm{u}$ istoj ustanovi postao je 11. lipnja 1936. godine. ${ }^{25}$ Urednik MSD bio je početnik i kao privatni i kao državni namještenik.

Iako Desnica nije imao građanski održive profesionalne alternative pravničkom pozivu, u sebi nije nalazio alternative ni svojim umjetničkim vokacijama, koje je kultivirao od djetinjstva i koje su bile sve prije nego hobističke. $^{26}$

Pojavljujući se kao mogući urednik časopisne publikacije u suradnji sa šibenskom Maticom, bio je praktično potpuno nepoznat u široj kulturnoj javnosti u Dalmaciji. Kako ništa nije bio objavio sve do 1932. godine, otvoreno je pitanje kada je prvi put uopće ponudio neki svoj rad nekom izdavaču? Iako je pisac 1965. već (polu)odgovorio na ovo pitanje, izbjegao je biti datumski eksplicitan:

što su bile moje. Ipak vjeruj che un giorno ti te ricrederà, come che mi me son ricrederà. Prije svega grješiš kad misliš da ti je ta struka zapreka i da radi nje nećeš moći da u punom opsegu valoriziraš mogućnosti koje osjećaš u sebi. Nije istina! Ti si i pored prava i pored ureda i pored Celigoja dao već dosada ne „mizerne člančiće“ već duboke i prvorazredne stvari. Uvjeren sam da bolje nebi dao ni da si mjesto Benjmog agrara, rješevao pitanja komparativne književnosti pred jednom acilom kretena i balavaca. Ovako si ti osposobljen za sve i ako nastane potreba (kao što neminovno hoće „quando cresce famiglia“) za većom zaradom ti ćeš zakoračiti u unosnu advokaturu, koja mene nije obogatila jer nisam za nju sposoban a ćaću (dr. Uroš Desnica - D.R.) jer je nezaslužno i neoprostivo na nju pljunuo, ali koja tebi otvara široke mogućnosti uspjeha i zarade jer si i pored tvog koprcanja za nju stvoren. Da ja imam la tua testa quadra vidio bi renomeje i banica! Nemoj dakle da se grizeš, doći će dan kad ćeš baš radi ovog zapaliti lumin ćaćinoj duši, ko što ga i ja danas palim onoj moga ćaće." (Boško Desnica - Vladanu Desnici, Karin, [?] [?] 1935., OOVD, kut. Prepiska do 1945. I.)

25 OOVD, kut. Služba i mirovina II.

26 D. Roksandić, „Ratni dani Vladana Desnice“, 533.

27 „Prvu novelu namenio sam 'Politici'“, Hotimično iskustvo. Knjiga druga, 105-106.

28 „Dragi gosp[odine] Vladane! Pismo sam primio šestog oktobra, pjesmu sam odnio skupa sa svojima 9 oktobra, a poslije toga još nisam govorio sa urednikom. On je zauzet jako oko novih knjiga Matice Hrvatske, koje uprav sad izlaze iz štampe. Ali on će je nema sumnje štampati. Samo će te izgleda čekati dva tri mjeseca. (...).“ (Olinko Delorko Vladanu Desnici, Zagreb, 31. 10. 1931., OOVD, kut. Prepiska prije 1945. I. Datum „X - 31“ upisan je naknadno 
...ako ipak pokušam da nekako odredim koji je moj rad pisan s namjerom da ga objavim, to je slučajno u nekoj vezi baš sa "Politikom“: dugo sam se mučio s novelom od pet-šest kartica koju sam bio namijenio „Politikinom“ podlistku „Priča Politike“.27

Tome radu zasad nema traga u piščevoj ostavštini.

U prepisci je ostalo sačuvano zagrebačko pismo Olinka Delorka od 31. listopada 1931., koje svjedoči da je jednu svoju pjesmu negdje u to vrijeme bio ponudio Matici hrvatskoj. ${ }^{28}$ Izgleda da je ona ipak nije objavila. To znači da je Vladan Desnica prije pokretanja $M S D$, u kojem će biti urednik i u kojem će tiskati nekoliko uistinu vrijednih a žanrovski različitih radova, doista bio početnik. ${ }^{29}$

Stvaralački, on se sâm sigurno nije tako osjećao. Deset godina kasnije, izgubivši kovčeg sa svojim rukopisima na putu brodom iz Splita u Zadar, 14. srpnja 1942., bio je očajan: „Ma koliko to objektivno moglo biti bezvrijedno, to za mene pretstavlja deset godina - i to najboljih deset godina - života i rada!“30 Drugim riječima, bio je mišljenja da su njegovih „najboljih deset godina“ počeli oko 1932./1933. godine. Oglasio se tada, kao što je već rečeno, „Izložbom vajara Dujma Penića u Splitu“ (odnosno „Kipar Dujam Penić: prigodom izložbe u Splitu“) i spomenutim „Jednim pogledom na ličnost Dositejevu“. Dakle, objavio je kritičke refleksije o opusu svoga starijeg splitskog suvremenika, s očitim afinitetima za njegovo kiparstvo te esejističke refleksije o Dositeju Obradoviću i njegovu opusu, o čovjeku romantičarskog senzibiliteta u osnovi inkompatibilna prosvjetiteljskoj epohi u kojoj je stvarao. Oba teksta imaju i estetičku i kulturnopovijesnu dimenziju te, što je najvažnije, oba otkrivaju Desnicu i kao čovjeka umjetničkih senzibiliteta, ali i kao mislioca koji uči i stvara u dijalogu s drugima, neovisno o epohi u kojoj su živjeli. Bio je i po ovim svojim kvalitetima, ali i po godinama kvalificiran za urednika publikacije kakva je u promijenjenim vremenima trebala nastaviti tradiciju Srpskodalmatinskog magazina dr. Božidara Petranovića, koji je bio, nota bene, istih godina kada je pokrenuo svoj časopis. Retrospektivno, bitno se razlikovao od dr. Petranovića.

Presudno je bilo što se stvaralački tada još uvijek tražio. Da tome nije bilo tako, da je bio bliži nekome kasnijem Vladanu Desnici, teško da bi išta htio imati s MSD. Kompromisni izlaz moglo se tražiti u časopisnom projektu u njegovim tadašnjim (ranih 1930-ih) unutrašnjim rascjepima između pravničkog zanimanja i umjetničkih i intelektualnih izazova. U tom

Desničinom rukom.) Dvije godine kasnije Vladan Desnica je preko Marka Cara pokušavao dogovoriti objavljivanje cijele zbirke pjesama u Beogradu, što je izazvalo burnu reakciju strica Boška kada je za to saznao: „Dakle ja sam da bel principio bio protivan da povjeravaš sudbinu zbirke onom fosiliziranom pižunu, koji se još u prvoj mladosti zabarikadirao iza par formula upljačkanih kod znamenitih kritičara: iz te barijere nije izašao cijeli život." (Boško Desnica - Vladanu Desnici, Obrovac, 2. 10. 1933., OOVD, kut. Prepiska prije 1945. I.) Sačuvano je još jedno pismo najvjerojatnije s istom zbirkom pjesama u vezi. Boško savjetuje Vladana (...): „Pjesme moraš svakako izdati. Nemoj izbacivati ništa, jer je greota iz ove zbirke žrtvovati i sami jedan stih a nadodaj nove. Anzi drago bi mi bilo da mi te nove pošalješ da ih pročitam. Šta znači 'u svojoj režiji'? Ako je to da on snosi trošak a ti preuzmeš da mu nadoknadiš eventualni gubitak onda je dobro, jer će se on postarati da ih plasira, ali ako ti moraš da mu unapred platiš, onda nije dobro, jer će se štrofotiti za prodaju, pošto je već sa štampanjem učinio posao.“ (Boško Desnica - Vladanu Desnici, Obrovac, 9. 9. 1934., OOVD, kut. Prepiska prije 1945. I.) 
je smislu MSD anticipativno za njega mogao biti čak i prava avantura. Morao bi biti urednik i autor, ali i tajnik Uredništva i računovođa itd. Ipak nije vjerojatno da je Desnica, slijedeći svoje artističke i intelektualne afinitete, sâm ozbiljnije tragao za ovakvim angažmanom prije nego što mu je bio predložen. Ako je i razmišljao, teško se odlučivao krenuti u posao koji je činio neizbježnim mnoštvo ljudi s kojima nije osjećao potrebu intenzivnije komunicirati. Nije bio inače sklon prihvaćati kompromise kada se radilo o njegovim artističkim i kulturnim interesima. ${ }^{31} \mathrm{~K}$ tome, teško da je bilo tko u Splitu u to doba, među ljudima njegovih artističkih afiniteta, mogao imati većeg razumijevanja za projekt $M S D$. Iznimke su bili Vladimir Rismondo, Ćiro Čičin Šain i Vjekoslav Parać. Subregionalni časopisi tada nisu bili u modi u Splitu, u gradu koji je inače sebe tražio na drugim, mnogo izazovnijim horizontima.

Vjerojatnije je pretpostaviti da mu je takvu ideju predložio kultivirani, praktični, ali i zabrinuti otac. Vrlo je vjerojatno da mu je sugerirao i poželjne identifikacijske obrasce: Srpsko-dalmatinski almanahlmagazin i lik njegova urednika, pravnika dr. Božidara Petranovića (Šibenik, 18. veljače 1809. - Venecija, 12. rujna 1871.). ${ }^{32}$ Vladanu su bili dobro poznati. Ova časopisna formula mogla se načelno razmjerno brzo primijeniti. Šibenska subregionalna Privredno-kulturna matica za Sjevernu Dalmaciju - s dr. Urošom Desnicom na čelu - i njezin Glas imali su namjeru pokrenuti periodičnu publikaciju. Ideja je očito bila intencionalne naravi. Nije bila unaprijed provjerena pa je i među involviranima doživljavana simbolički, a prosuđivana instrumentalistički. ${ }^{33} \mathrm{~S}$ promjenom okolnosti, nesporazumi i sukobi bili su neizbježni. Godine 1932., kada je Vladan Desnica pokrenuo inicijativu, a njegov otac postao senator, izgledalo je da ništa ne bi moglo loše krenuti.

Ulazeći u projekt $M S D$ sa svim svojim višestranim umjetničkim i kulturnim vokacijama i interesima, a opterećen tjeskobama svakodnevnih profesionalnih rutina, Desnica je prihvatio izazov i zato što mu je časopis mogao osigurati zajamčenu mogućnost objavljivanja svojih radova, ali i radova njegovih umjetničkih prijatelja. Objavljivati u to doba inače nije bilo ni jednostavno ni jeftino.

$S$ Matičine strane, mladi, višestrano obrazovani Desnica, čovjek s jakim obiteljskim zaleđem i izglednom profesionalnom budućnošću mogao je biti prihvatljiv urednik među Srbima u Dalmaciji priželjkivane periodične publikacije, nasljednice dugovječnoga Srpsko-dalmatinskog almanahalmagazina. Kao čovjek koji je 1932. imao dvadeset i sedam godina te, k tome, koji je godinama bio izvan Dalmacije morao je biti nepoznanica većini aktera u Matici, koliko god ga mogli manje ili više osobno poznavati. U usporedbi s Petranovićevim časopisom, Desničin $M S D$ više je ovisio o „drugima“. Nepoznanica su bili i „oni“ za njega, neovisno o tome što je sve obiteljski i profesionalno mogao saznavati o ljudima iz šibenske Matice.

31 D. Marinković, „Biografija Vladana Desnice“, 223-224. Vrlo je upečatljivo sjećanje Rade Ležaića, njegova školskog kolege iz Šibenika: „Bio je jako razvijen mladić, neobično lijep, uvijek dobro obučen i dotjeran. Pa ipak, po tome je bio manje zapažen, a više što je bio sin doktora Uroša Desnice, ondašnjeg senatora, i po tome što je bio potomak Jankovića. Bio je vrlo bistar đak i uvijek je prolazio s odličnim uspjehom. Ponosan na svoje pretke i na položaj svoga oca, držao se prilično visoko i uobraženo. Po koji put ne bi pozdravljao ni profesore kad bi ih susreo na ulici ... Na momente bio je veoma nagal i imao jako raspaljive živce, pa je za sitne stvari znao planuti. Puno je čitao i uvijek nešto pisao..." (Isto, 223).

32 Ivo Perić, „Politička i kulturna djelatnost Božidara Petranovića“, Radovi Zavoda za hrvatsku povijest, 16/1983., 45-96.

33 Odgovor, 30. 


\section{ZaViČajnosti mladog Vladana Desnice i MAGAZIN SJEVERNE DALMACIJE}

Prije ulaska u časopisni projekt Desnica je sazrijevao prije svega - nužno je naglasiti - u svojoj obitelji i među ljudima koji su s njome na različite načine bili bliski (neovisno o tome gdje je sve obitelj kada živjela i gdje su se sve njezini članovi nalazili). Nužno je naglasiti „sazrijevao“:

Otac mi je bio čovjek velike kulture, ne samo opće nego i literarne specijalno, i vrlo istančanog ukusa, odličan stilista i tako. U familiji se uopće to gajilo i čak četiri ili pet generacija unatrag ima tragova da su imali toga crva, toga crva pisanja, da tako kažem. I tako čitava me ta sredina ... Stric je isto bio vrlo kulturan čovjek sa smislom za literaturu; prevodio je; čak je prevodio nešto Matavulja na talijanski. Literatura, historija, povijest umjetnosti i filozofija, ali u prvom redu literatura, nekako je bilo in patrimonio kod mene u obitelji i od najranijih godina sam na to upućen. ${ }^{34}$

Od svojih najranijih dana kretao se između Zadra, Obrovca i Islama, tj. između sjevernodalmatinskog priobalja i zaobalja, uključujući Ravne kotare i Bukovicu, a vrlo brzo, praćen roditeljima, krenuo je i na druge strane, najprije „mletačke“. U „Velikom ratu“- koji je za njegovu obitelj počeo i završio očevim internacijama, 1914. u Hercegovini i 1919./1920. u Italiji - slijedio je oca s majkom gdje god je mogao (više mjeseci u Italiji, u Umbriji i Rimu). Nakon obiteljskog odlaska iz njegova rodnog Zadra u Split, gdje se otac našao slijedeći imperative svoje političke djelatnosti i državne službe 1920./1921., Desnica je upoznao uvelike drugačiju Dalmaciju. Od 1921. do 1930. najčešće je sâm živio u Šibeniku i Zagrebu te Parizu, a zakratko ponovno u Veneciji itd. Desničini svjetovi već do njegove dvadeset i pete godine, kakvi god gdje bili, koliko god mogli biti zatvoreni, imali su uvijek svoje iskustvene „protu-svjetove“. Pojam „zavičajnosti“ mu je nužno bio stran u lokalističkom smislu jer ga je od najranijih dana, gdje god se našao, doživljavao u oprekama, proturječjima, uključivostima i isključivostima.

Zavičajni svijet je za njega bio prije svega svijet obiteljskih doživljaja i iskustava, duboko saživljenih s dalmatinskim i mediteranskim podnebljem. ${ }^{35}$ Tim lakše su Dalmacija i Me-

34 J. M. Milović, „Razgovor s Vladanom Desnicom“, 124.

35 Pisma strica Boška sinovcu Vladanu iz tog doba već svojim stilom i jezikom vjerno reflektiraju dalmatinski/mediteranski mentalitet obitelji: „Dragi Vladane, kaže mi kum, koji je ovgje progostovao Sv. Savu, da se tužiš na mene radi Magazina. Priznajem da imaš donekle pravo, ali kako znaš, bio sam bolestan i, kako neznaš, imao sam raznih natezanja lokalnog karaktera i onda nadodaj zimu, koju ja teško podnosim i koja mi formalno paralizuje sve sposobnosti. Sad je sve to nekako prebrogjeno a i studen je popustila, pa ću iskupiti obećanje." Objašnjavajući sinovcu zašto neće za $M S D$ „obragjivati“ smrt Stojana Jankovića, što je ovaj bio zatražio, upozorio ga je da je već objavio rad na tu temu i dodao da mu „i onako predbacuju da se navraća(m) na iste teme, ka mačka na bljuvotinu“ i na kraju „almanaku bi to dalo karakter jedne od onih porodičnih, panegiričnih publikacija, koje su bile uobičajene u mletačkom plemstvu in occasion de nozze“. Obećao mu je „odma po tom probrati nekoliko zanimljivih dokumenata koje ću prevesti i (nečitko - D.R.) notama i natpisom: Nekoliko priloga istorijskom proučavanju nar[odnih] pj[esama] nagjeni u dokumentima,..." Završio je s laganom notom poduke: „Mislim da će to biti bolje più vario, più interessante a osim toga sve to nije bez važnosti za nauku koja proučava nar[odnu] epiku (Soerensön, Gesemann, Tomić, Popović, Ćorović i t.d. va pazzi za ovake gurmanluke). Piši kabuliš li i piši a che punto semo sa Magazinom." (Boško Desnica - Vladanu Desnici, [Obrovac, 1. 2. 1933.], OOVD, kut. Prepiska do 1945. I.) Na kraju je stric u MSD 1934. bio zastupljen s prilozima „Nekoliko priloga istorijskom proučavanju narodne pjesme“, „Vuk Mandušić“, „Zamunički događaj“ i „Smrt Stojana Jankovića i seoba ramskih franjavaca u Dalmaciju“. 
diteran u translokalnom smislu, shvaćeni i kao Priroda i kao Kultura, mogli biti njegov „Zavičaj“ u prostornom smislu: „Dalmacija i Mediteran i mediteransko podneblje su jako mnogo utjecali na mene. $\mathrm{O}$ tom nema govora. I čitav bih ja bio sasvim drukčiji da nisam na tom području odrastao i rođen tu. ${ }^{\text {"36 }}$

U ranim 1930-ima, kada je prihvatio izazov uređivanja sjevernodalmatinske periodičke publikacije, pojam „Sjeverna Dalmacija“ je za njega bio sociokulturni konstrukt jer ju je dotad već bio doživio, kako iznutra tako i izvana, i kao svojevrsni makrokozam u mikrokozmu. ${ }^{37}$ Bilo kakva skučena, utilitarna upotreba tog pojma bila je za njega neprihvatljiva. U osnovi, i u slučaju „Sjeverne Dalmacije“, ključ za razumijevanje njegovih pristupa mogla je već tada biti samo subregionalna refleksija univerzalne conditio humana. ${ }^{38}$ Urednički je svoje uvjerenje ovako sažeo u nenaslovljenom predgovoru prvom svesku MSD:

Život ovoga kraja, njegove potrebe i njegove duhovne težnje, bar u principu, jednako su važni kao i život, potrebe i težnje ma kojeg drugog kraja. Ali su one, iz raznih uzroka, manje vidne i manje uvažavane. - „Magazin“ ima da bude pregled našeg javnog života, naših prilika i potreba i izraz naših težnja, te da ih učini vidnijim i uvažavanijim. ${ }^{39}$

\section{Što su bili Privredno-kulturna matica za Sjevernu Dalmaciju (I928. - i936.) i GLAS Matice (I929. - i936.)?}

Budući da ovaj rad ne iziskuje cjelovitije istraživanje problematike povijesti Privrednokulturne matice za Sjevernu Dalmaciju (1928. - 1936.) i njezina Glasa (1929. - 1936.), ograničit ćemo se na aspekte koji su neizbježni kada je riječ o odnosima Vladana Desnice i MSD s Maticom i Glasom od 1932. do 1935. Riječ je o periodu od prvih kontakata u vezi s MSD do klimaksa javnih sukoba u razdoblju između ubojstva kralja Aleksandra I. i parlamentarnih izbora 1935 . godine. ${ }^{40}$

Matica je bila utemeljena u vrijeme velikog deziluzioniranja i iznevjerenih očekivanja od „narodne države“ - kako je Glas obično pisao - u sjevernoj Dalmaciji u razdoblju nakon razgraničenja s Italijom 1920. godine i postupnog integriranja u pravni poredak Kraljevine SHS, koje je završeno tek 1923. godine. Krizu povjerenja pojačavali su učinci neuspješnog izvođenja agrarne reforme u Dalmaciji, opterećene vlasničkim osnosima koji su potjecali iz doba Mletačke Republike. Iako je pitanje agrarne reforme bilo otvoreno u Habsburškoj Monarhiji od 1848. do 1918. godine, ostalo je otvoreno i u svome novom ciklusu od 1919. do 1928. godine u Državi SHS/Kraljevini SHS. Sporne učinke najteže su podnosili seljaci u najnerazvijenijem dijelu pokrajine, tj. u kontinentalnoj sjevernoj Dalmaciji. ${ }^{41}$ Gubitak

\footnotetext{
36 J. M. Milović, „Razgovor s Vladanom Desnicom“, 125.

37 „Sjeverna Dalmacija” se kao pojam dosljedno koristi u MSD.

38 Zimsko ljetovanje tome je najbolji dokaz u njegovu opusu, kada je o „Sjevernoj Dalmaciji“ riječ. Kada je riječ o Vladanu Desnici, Proljeća Ivana Galeba su pored ostalog i roman o tjeskobama zavičajnosti.

39 MSD, 1/1934., 3 (ćir.).

40 „Pitanje Matičina 'Almanaha' ili uloga mladoga Desnice“, Odgovor, 29-34 (ćir.).

41 Vidjeti članak Šime Pilića u ovom zborniku radova.
} 
Zadra još više je marginalizirao ovo kontinentalno zaleđe. Aneksionističke aspiracije sjevernodalmatinskih Hrvata i Srba do 1923. godine bile su poražene nakon 1923. godine. Izostala je bila bilo kakva osmišljena alternativna subregionalna razvojna politika, kako ona orijentirana prema Šibeniku tako i ona orijentirana prema Kninu.

Time su politički najpogođeniji bili dalmatinski radikali jer su gubili i kredibilitet i legitimitet u dijelovima Dalmacije gdje su bili najutjecajniji. ${ }^{42}$ Ponaprije među njima nametnula se potreba za subregionalnim inicijativama koje će preduprijediti moguću agrarnu radikalizaciju u trenutku kada je toliko drugih neuralgičnih pitanja u Kraljevini SHS već bilo otvoreno. Moguće rješenje vidjelo se u depolitizaciji ključnih razvojnih pitanja u sjevernoj Dalmaciji. Tada je to značilo - pored ostalog - povratak zapuštenim tradicijama zadružnog pokreta koji je u Dalmaciji bio razvijen i među Hrvatima i među Srbima na prijelazu 19. u 20. stoljeće. ${ }^{43}$ Do 1913./1914. godine, samo dalmatinski Srbi u granicama austrijske krunovine Dalmacije bili su utemeljili 42 zadruge tipa Raiffeisen, 10 tipa Schultze-Delitzsch i 5 produktivnih tj. 3 uljarske i 2 ribarske. ${ }^{44}$ Od 1903. do 1914. godine, uvelike zahvaljujući i politici zajedničkoga hrvatskog i srpskog „novog kursa“, razvilo se u Dalmaciji po prvi put mnoštvo gospodarskih i kulturnih društava i udruženja sa srpskom regionalnom atribucijom (Srpska zora, Matica srpska /Dubrovnik/, Srpske zemljoradničke zadruge, Srpske kreditne zadruge itd., itd.). U Dalmaciji je djelovalo i zagrebačko Srpsko privredno društvo „Privrednik“. Različite zadudžbine (zaklade) omogućavale su nastavak školovanja za različita svjetovna zanimanja svršenim đacima Srpskog pravoslavnog sjemeništa i Srpske pravoslavne bogoslovije u Zadru, inače financiranima iz zemaljskog proračuna. ${ }^{45}$

Svega je toga nestalo između 1914. i 1918. te nakon 1918., a da poslije rata nije bilo supstituirano održivim regionalnim ustanovama i razvojnim projektima „narodne države“. Bilo je više pokušaja da se djelatnost Glavnog saveza srpskih zemljoradničkih zadruga proširi u jugoslavenskim razmjerima gdje god su za to postojale mogućnosti pa je i u Kninu 1. siječnja 1924. počela s radom filijala Glavnog saveza. Prestala je djelovati već 1929. godine. Neovisno o različitim manje ili više uspješnim inovacijama u subregionalnom zadrugarstvu, razvojne potrebe su postojano bile mnogo veće nego njihovi konkretni učinci. ${ }^{46}$

$\overline{42}$ Detaljnije u: Čedomir VIšnjIĆ, Srbi u Hrvatskoj 1918-1941: anotirana bibliografija, Zagreb 2000.; Gordana KRIVOKapIĆ Jović, Oklop bez viteza. Organizacione osnove i socijalna struktura NRS-a u Kraljevini SHS 1918-1929, Beograd 2001. (ćir.); Sofija Božić, Srbi u Hrvatskoj 1918-1929., Beograd 2008. (ćir.).

43 Zadružni pokret izvorno se razvio se u njemačkim zemljama nakon 1850. godine. Hermann Schultze-Delitzsch (1808. - 1883.) i Friedrich Wilhelm Raiffeisen (1818. - 1888.) njegovi su utemeljitelji. Nastao je s ciljem da ruralni i urbani niži društveni slojevi korištenjem načela samopomoći zaštite svoje interese u procesu kapitalističke transformacije tradicionalnih društvenih zajednica. Razvio se u više europskih zemalja, najčešće u funkciji ubrzanja prvobitne akumulacije kapitala u gospodarstvima europske (polu)periferije. Vidjeti: J. Carroll Moody - Gilbert C. Fite, The Credit Union Movement: Origins and Development 1850-1980, Dubuque (Iowa) 1984.; Ian MACPHERSON, Hands Around the Globe: A History of the International Credit Union Movement and the Role and Development of World Council of Credit Unions, Inc., Victoria (Canada) 1999. Čelnici Matice bili su obaviješteni o razvojnim mogućnostima zadrugarstva: „Mi se nalazimo pred onim istim zadacima, pred kojima su se nalazili 'Ročdelski pioniri' u Engleskoj pred nepunih stotinu godina, Rafajzen pred malo više od pola vijeka u Njemačkoj, biskup Gruntvig i njegovi učenici u Danskoj... („Iz Bukovice i Ravnih Kotara“, Glas, 5/1933., br. 140, Šibenik, 1. 3. 1933., 1.)

44 Severna Dalmacija nekad i sad, 56-57.

45 Isto, 49-57.

46 Severna Dalmacija nekad i sad, 77-92. 
Stanje u najnerazvijenijim dijelovima Dalmacije, posebno onima u sjevernoj Dalmaciji pretežno nastanjenim srpskim stanovništvom, realno se nesumnjivo pogoršavalo. Razvojni učinci poratne konjunkture nisu dopirali do tih krajeva, a modernizacijski pomaci u priobalju, koliko god bili ograničeni, povećavali su razvojne razlike unutar pokrajine. Time su se u kontinentalnoj sjevernoj Dalmaciji dodatno usložnjavali nacionalni odnosi, iako su tamošnji žitelji obje narodnosti dijelili u osnovi iste životne (ne)prilike.

Pojam „Sjeverna Dalmacija“, u smislu distinktivne dalmatinske subregije, a ne tek sjevera Dalmacije, izgleda da se ustalio baš u tim godinama nakon međudržavnog razgraničenja. Izvorno nije imao nacionalno polarizacijski smisao. Zbor Ravnih kotara u Zemuniku, 17. listopada 1925., organizirali su zajednički don Šime Lukić, dr. Uroš Desnica i Lazar Matić i tom je prilikom zaključeno i što je Sjeverna Dalmacija:

...pitanja Sjeverne Dalmacije ne smiju (se) lokalizirati, jer je cijela Sjeverna Dalmacija jedna posebna cjelina, sa svojim Primorjem, Zagorjem i Otočjem, u privrednom, kulturnom i državnom strategijskom pogledu. ${ }^{47}$

Kasnija nacionalna polarizacija dovest će u pitanje takvo poimanje, orijentirajući Hrvate uglavnom prema priobalju, a Srbe uglavnom prema Bosanskoj krajini i Lici.

Kada je o Srbima u Dalmaciji riječ, ključno je ipak bilo što je građanstvo srpske narodnosti u primorskim gradovima - nerijetko koristeći različite klijentelističke pogodnosti u novostvorenoj državi, ali uživajući i prednosti modernizacijskih promjena u priobalju općenito - interesno i mentalno postajalo sve udaljenije od svojih najčešće zavičajnih predjela u zaobalju, koji su mu i dalje u parlamentarnim uvjetima osiguravali politički utjecaj. ${ }^{48}$ Stvaranjem Privredno-kulturne matice za Sjevernu Dalmaciju htjelo se zaustaviti i taj proces te i sa srpske strane interesno reintegrirati priobalje i zaobalje. Napominjemo da je Hrvatska republikanska seljačka stranka do tog doba već bila uvelike integrirala dalmatinsku obalu, zaobalje i priobalje te sjevernu, srednju i južnu Dalmaciju, u osnovi marginalizirajući hrvatske političke orijentacije $s$ jugoslavenskim atribucijama. ${ }^{49}$

Stvaranjem Matice, napokon, htjelo se u novim uvjetima dati smisao baštinjenim predratnim zadružnim iskustvima. Pretpostavljalo se da će državna vlast pod pritiskom Matice imati više razumijevanja za razvojne potrebe krajeva koji su uvelike vlastitom voljom, aktima samoopredjeljenja (neovisno o jednoj ili drugoj nacionalnosti), aneksionističkim pokretom delegitimirali odredbe Londonskog ugovora 1915. godine i odvojili svoju budućnost od budućnosti izgubljenog Zadra, svoga tradicionalnog subregionalnog centra. $\mathrm{Na}$ kraju krajeva, kralj Aleksandar I. načelno je podržavao razvitak zadrugarstva u Jugoslaviji. ${ }^{50}$

Osnivačke skupštine Matice bile su održane u Kninu, prva na pravoslavni Uskrs i druga uoči Vidovdana, 27. lipnja 1928. godine:

47 „Zbor Ravnih Kotara u Zemuniku 17. oktobra 1925.“, Glas, br. 1, 21. 3. 1929., 6.

48 Detaljnjije u: G. Krivokapıć Jović, Oklop bez viteza; S. Božıć, Srbi u Hrvatskoj 1918-1929.

49 Detaljnije u: Aleksandar JakiR, Dalmatien zwischen den Weltkriegen, München 1999.

50 „Danas više no ikada treba da je svakom jasno, da je zadrugarstvo najizrazitiji oblik privrednog održanja i društvenog poretka našega sela.“ (Citirano prema: L[azar] M[ATıć], „Sudbonosna istina“, Glas, br. 153, 15. 6. 1933., 1 (ćir.).) 
Došli su i Srbi i Hrvati iz svih mesta Severne Dalmacije, i pripadnici svih političkih grupa. Skupštini je pretsedao pok. Miho Novaković, ondašnji pretsednik radićevske Oblasne skupštine u Splitu, a s njim su došli i ostali članovi Oblasne skupštine, koji su bili iz Severne Dalmacije. Na skupštini su pretresena pravila i društvu je dano ime „Privredno-prosvetna matica za Severnu Dalmaciju“. Organizacija je osnovana po zakonu o društvima, kao što je svojevremeno po tome zakonu postojao i Savez srpskih privrednih zadruga na Primorju. U članstvo se odmah prijavilo mnogo članova, i to zadruga, opština, crkava, raznih društava, ustanova, pojedinaca. Zaista se je vršila koncentracija u celom jednom kraju, koji je najviše stradao, i stvari su se počele razvijati vrlo lepo. ${ }^{51}$

Matičin Glas, koji je počeo izlaziti 21. ožujka 1929., od početka je populistički promicao društveno hijerarhiziranu, implicitno klijenteličku mrežu odnosa unutar Matice:

Mi se nalazimo u teškim prilikama. Glad, golotinja, bosotinja, bolest, nevrijeme nezapamćeno u našim krajevima, pored naših starih teških prilika življenja, prijete da unište naše krajeve. Sve se nalazi u očajnom stanju. Naše su vjekovne želje za slobodom ispunjene, ali naša sloboda ne ispunjava se zadovoljstvom, ljepšim i boljim življenjem, već se nalazimo na rubu propasti. Veliki duh našega naroda u nama se gasi, jer duša u tijelu jedva diše. (...) Najrazumniji seljaci, najbolji učitelji i sveštenici, agronomi, profesori, ljekari, pravnici, inžinjeri, veterinari, svoje misli i brige posvećuju ovom napaćenom dijelu svoje Otadžbine, da sačuvaju naša ognjišta od pustoši, da naši krajevi opet ožive. Izabraniji trgovci, obrnici, industrijalci vide u tom i za se jedino mogući razvoj. ${ }^{52}$

U promijenjenim, kriznim uvjetima - prema Glasu - „privreda je postala najglavnije pitanje“, s tim što „bez prosvijećenosti nema dobre privrede“, kao što i „bez kulture cijelom narodu življenje je nemogućno i suvišno“. 53 List je dosljedno koristio pojam „narodna inteligencija" u neoromantičarskom stilu:

Svi redovi narodne inteligencije mjesto nejasne slike o narodu, osjetiće radost, kad vide žive ljude pred sobom, u boljim prilikama života, gdje svijetle sa poštenjem, pameću, i svim velikim i lijepim osobinama našega naroda. ${ }^{54}$

Ovi patetični akcenti na teme socijalne harmonije bili su ipak duhovno normativno usmjereni: „Duh naše starine osnov je naše Matice, a duh kulture njen pravac rada." ${ }^{\text {"D }}$

Razdoblje između ubojstava u Skupštini Kraljevine SHS 20. lipnja 1928. godine i 6. siječnja 1929. bilo je sve prije nego idealno za slične inicijative. Matica se brzo svela na javnu tribinu službeno zabranjene Narodne radikalne stranke na Primorju. Cijela je njezina strategija „hoda kroz institucije“ poretka s ciljem lobiranja za lokalne i subregionalne razvojne inicijative nakon 6. siječnja 1929. bila u osnovi obesmišljena. Budući da je Matica bila mobilizacijski i reprezentacijski zamišljena, u novim uvjetima njezina djelovanja postalo je

\footnotetext{
Severna Dalmacija nekad i sad, 92.

„Glas Sjeverne Dalmacije“, Glas, br. 1, 21. 3. 1929., 1 (ćir.).

Isto.

Isto.

55 Isto, 2. Prema istom izvoru, prvo čelništvo Matice činili su: „Sekretar: Lazar Matić / Predsjednik: Dr. Uroš Desnica / podpredsjednik: Ante Oštrić / Članovi Upravnog odbora: Bilić Dušan, učitelj; Dabić-Bečker Stevo, učitelj; Drezga Petar, učitelj; Knežević Sava, zemljoradnik; Novaković Dušan, školski nadzornik u m.; Opačić Petar, zemljoradnik; Pokrajac Veljko, načelnik; Stojsavljević Petar, sveštenik; Rašković Dušan, sveštenik; Triva Marko, profesor; Zelić Pavle, sveštenik."
} 


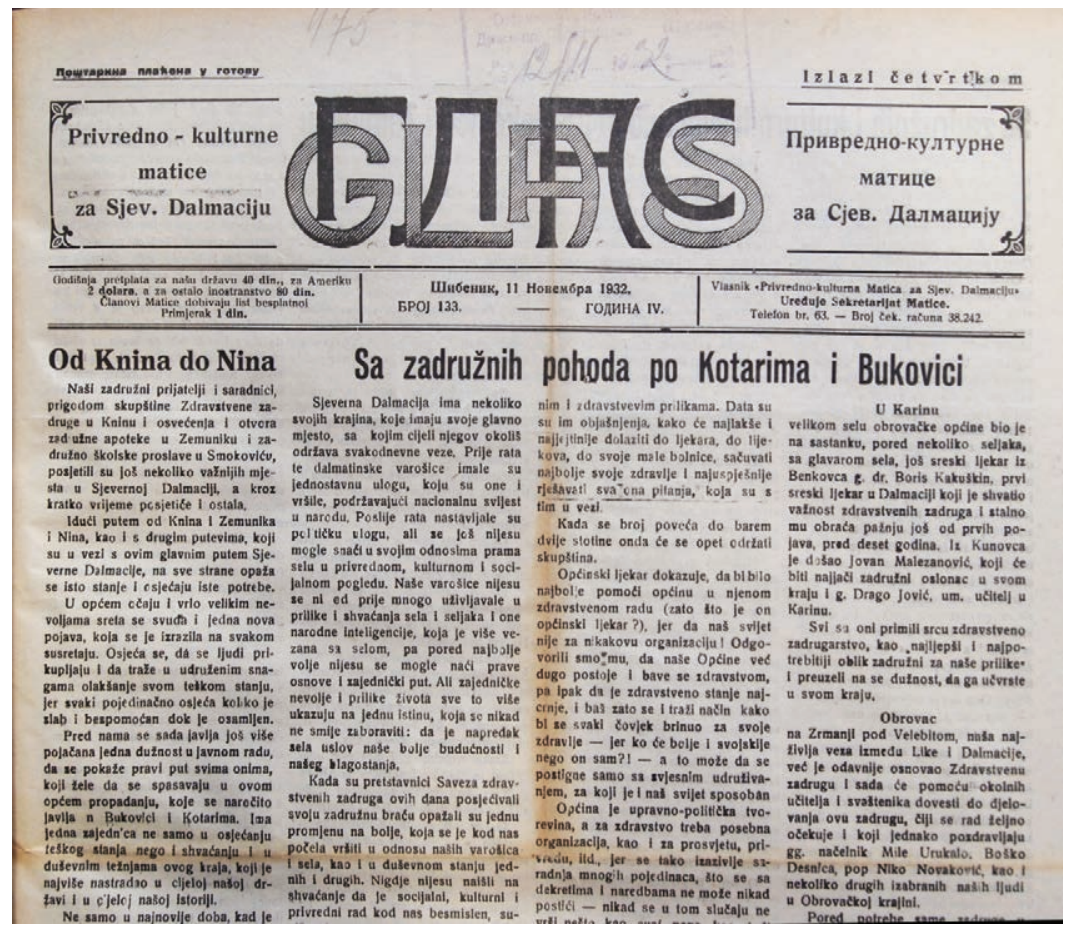

Sl. 2. Glas Privredno-kulturne matice za Sjevernu Dalmaciju: za „šumadijsku“, a protiv „prečanske“ kulturne paradigme

još važnije razvijati njezinu funkcionalnu infrastrukturu, kako prema unutra, tako i prema vani. ${ }^{56} \mathrm{Na}$ Matičinoj godišnjoj skupštini 1930. godine odlučeno je „da se osnuje ‘Privredni savez', sa sjedištem u Kninu i sa djelokrugom na cijeloj Primorskoj Banovini. Isti se ima za sada registrirati kao zadruga, koja će imati svoje poslovnice po raznim mjestima Primorske Banovine, naročito Zagorja,..... U Upravni odbor su izabrani dr. Nikola Subotić kao predsjednik i dr. Uroš Desnica kao potpredsjednik..$^{77}$ Međutim Privredni savez, praktično stvoren u „zrakopraznom“ prostoru, imao je u najboljem slučaju legitimacijski smisao za njegove čelnike. Ključni akteri, dr. Subotić i dr. Desnica, mogli su imati interesa za Maticu i njezine inicijative utoliko ukoliko im je osiguravala još poneku mogućnost javnog djelovanja i jačanja utjecaja u promijenjenim političkim uvjetima. Sve drugo postalo je nakon 6. siječnja 1929. nerealno. Tako je bar razmišljao dr. Desnica. Nakon što je 1932. postao senator, nestao je i minimalni njegov interes za Maticu. ${ }^{58}$

Međutim, više lokalnih i subregionalnih aktera u Matici i Glasu, koji osobno nisu imali poslovne alternative započetim i/ili zamišljenim poslovima, nije mogao prihvatiti pomisao o prestanku djelovanja Matice i izlaženju Glasa. Njihova ljutnja na srpske dalmatinske potentate bila je isto tako velika kao i odlučnost da u promijenjenim uvjetima djelovanja osiguraju „strateškog partnera“. Dobili su ga u novom dalmatinskom vladici dr. Irineju Đor-

\footnotetext{
56 Severna Dalmacija, 92.

57 „Godišnja skupština P[rivredno]-K[ulturne] Matice“, Glas, br. 45-46, 30. 1. 1930., 1 (ćir.).

58 To je argument koji se provlači Odgovorom kao crvena nit.
} 
đeviću 1931. godine. ${ }^{59}$ Matičin Glas ga je od dolaska s entuzijazmom podržavao. Sadržaj lista se postupno sve više konfesionalizirao. Jugoslavenski integralizam u srpskopravoslavnoj intonaciji u Dalmaciji bio je odbojan i brojnim ljudima srpske nacionalnosti, naročito u gradovima. Obrasci konfesionalizacije slijedili su $\mathrm{k}$ tome prakse utjecajnog vladike dr. Nikolaja Velimirovića. Što se Matica manje bavila poslovima zbog kojih je bila osnovana, njezin Glas je u duhu svoje nove politike sve više javno prozivao odgovorne za katastrofalno stanje u Dalmacije, naročito u Sjevernoj Dalmaciji. Sukob se prividno sve više pretvarao u sukob vladike Irineja i dr. Desnice, s mnoštvom smicalica i političkih podvala pa i insinuacija na obje strane.

Eruptirao je na Matičinoj godišnjoj skupštini 15. ožujka 1933., održanoj u Svečanoj sali Vladičanskog dvora u Šibeniku. Neuobičajeno veliki broj nazočnih, uglavnom anonimnih u Matici, predsjednik Matice dr. Desnica doživio je kao alarm pa je otvarajući skup rekao da se raduje brojnoj posjeti skupštine, ,ali pod uslovom da ovo ne bude Matičino opijelo, već njezin pir. Ima puno razloga da to kaže, jer i ako je interesovanje za ovu skupštinu priznanja dostojno, ne može se to isto kazati i za interesovanje i saradnju naših ljudi u Matičnim brigama i naporima koje je dosad činila na ostvarenju svojih ciljeva i programa." ${ }^{\circ 0}$ Ovakav predsjednikov istup, koliko god očito bio neočekivan, nije spriječio sekretara Matice Matića da iznese prijedlog koji je članstvo trebao suočiti s činjenicom da Matica ulazi u svoje novo doba: „... g. Matić potsjeća prisutne za jedan lijep običaj, koji vlada u svim slojevima velikog britanskog naroda: da se svaki - i privatni i javni posao počinje sa molitvom. (...) Time bismo učinili i akt pažnje prema našem domaćinu koji je vaspitanik engleske kulture i sljedbenik naših lijepih tradicija. "61 Skupština je prijedlog jednoglasno prihvatila, a zamoljeni vladika Irinej počeo je glasno čitati „Oče naš...“. Spominjanje „Matičina opijela" u Vladičanskom dvoru ipak je izazvalo domaćina da pokuša anulirati učinak predsjednikovih riječi i preusmjeriti skupštinu u pravcu koji je vjerojatno bio unaprijed dogovoren: „Osvrnuvši se na lijepu simboliku imena Matica, koja nam napominje košnicu, kao najsavršeniji oblik zadružne misli, što nam je kroz pčele daje Bog, nada se i Boga moli da i ovaj Matičin roj, koji je danas ovamo sletio, ne bude njen pogrebni zbor - po zloj slutnji g. pretsjednika - već uistinu njen pir, koji će značiti njeno ponovno rađanje, sa novim naporima i ciljevima, a daj Bože i - plodovima." ${ }^{\text {“2 }}$ Međutim, o harmoniji košnice na skupu ipak nije moglo biti govora jer je ponajprije sekretar Matić morao obrazložiti nezavidno stanje u

59 Irinej (Milan) Đorđević (Vrnčani, 22. 5. 1894. - Cambridge, 27. 8. 1952.) bio je jedan od najobrazovanijih teologa u Srpskoj pravoslavnoj crkvi, s doktoratima stečenima u Oxfordu i Ateni. U ratnim godinama bio je, pored ostalog, šef Presbiroa srpske vlade u Londonu, a i u poslijeratnim godinama održavao je brojne međunarodne veze. Vladika dalmatinski bio je od 2. listopada 1931. sve do svoje smrti. U međuvremenu je od 1935. do 1938. bio administrator američko-kanadske eparhije. Od 1941. do 1943. bio je u fašističkoj internaciji u Italiji. U ratnim godinama bio je jedan od ključnih aktera Političkog ogranka Centralnog nacionalnog komiteta Ravnogorskog pokreta, a nakon 1945. jedan od utjecajnijih aktera u srpskoj političkoj emigraciji na Zapadu. Posljednje godine života proveo je na Sveučilištu u Cambridgeu. Njegovi Odabrani radovi objavljeni su u Gornjem Milanovcu 2003. godine. Vidjeti biobiliografski zapis u: Irinej ĐorĐević, Odabrani radovi (prir. Dragan Subotić i Borislav Čeliković), Gornji Milanovac 2003., 297-322 (ćir.).

60 Izvještaj Glasa s ove skupštine na sažet način sugestivno prikazuje dinamiku konflikta: „Godišnja skupština P[rivredno]-K[ulturne] Matice“, Glas, br. 45-46, 30. 1. 1930., 2 (ćir.).

61 Isto.

62 Isto. 
kojem se Matica nalazila. Pokušao je odgovornost prebaciti na predsjednika: „.., moram kazati, da Matica kao samostalno društvo nije ništa učinila u posljednje dvije godine, jer se za takav rad pretpostavljaju srestva, kojih Matica nema. Ona je bila prisiljena da se održava milostinjom, isforsiranim pomoćima pojedinaca i pokoje javne ustanove, pretplatom svog organa, prilozima i članarinom svojih članova, a sve to u tako oskudnoj mjeri, da je Matica jedva uspjela da održi svoj list. “"33 Neizbježnu kakofoniju pokušao je presjeći dr. Desnica, obnavljajući svoj prijedlog s početka skupštine: „U jednom momentu ustaje pretsjednik g. dr. Uroš Desnica, koji reče otprilike: ' - Gospodo i braćo, znate li vi ko je Matica? Sa malo rezerve ja bih kazao da je Matica g. Lazar Matić i - pik! (...) Ne vrijedi se, gospodo, obmanjivati. Nismo mi za ništa, nego ja predlažem da mi lijepo pokopamo Maticu, pa da idemo kući, i da u postu i molitvi okajavamo svoj nehat i neshvaćanje vremena u kome živimo.'“64 Radikalnost prijedloga zatekla je i kritičare postojećeg stanja svih provenijencija u Matici pa njezin predsjednik izgleda nije dobio ničiju podršku, što je umješno iskoristio osobno najzainteresiraniji, Matić, da predloži izbor vladike Irineja za predsjednika Matice: „Ima među nama jedan čovjek, koji po svom položaju, svojim stečenim i bogodanim osobinama, daje nade, da bi Matica, pod njegovim rukovodstvom, mogla da se izliječi od malo-

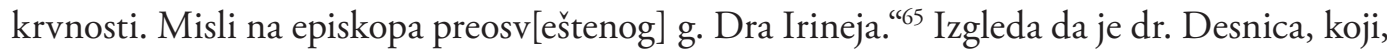
iako osobno nije imao nikakva interesa ponovno biti biran, bio uvjeren da će se kao kandidat pojaviti netko dobro poznat iz kruga „matičara“. Njega je iznenadila sama pomisao da bi se vladika dalmatinski mogao javiti kao kandidat za predsjednika jednoga svjetovnog društva, $\mathrm{k}$ tome doslovno u izumiranju. Za dr. Desnicu je to morao biti simptom obnove bitaka koje je već prije 1914. godine smatrao dobivenima. Jedino tako se može razumjeti nota nevjerice, ali i načelnog nesuglasja koja je izbijala iz njegove reakcije: „G. dr. Desnica ističe da ova kombinacija ima dobrih, ali i nezgodnih momenata. U pretpostavci da bi se g. episkop htio primiti ove karike (g. episkop se poslije molitve udaljio sa skupštine) vjeruje da bi to mogao biti jedini i posljednji blagonadežni pokušaj, ali on ne bi htio da makar s koje strane izbije prigovor, da se Matica poklerikalila. (...)"66 Budući da je izostala bilo kakva reakcija u dvorani koja bi mu išla u prilog, očito nije htio da se skup završi a da ne bude kristalno jasna odgovornost sviju onih koji su Matićev prijedlog podržali:

G. dr Desnica: „...mi smo tu, a vi znate da kod nas takve tendencije nisu nikad palile. Za to vas molim, gospodo, da svak iskreno kaže svoje mišljenje." (Slažemo se!) (...) Pošto je pretsjednik još jednom, a malo potom i po treći put upitao, da li ko ima da prigovori iznesenom predlogu i niko se nije javio, dana je pauza, a g. dr. Desnica, međutim, otišao sa izaslanstvom da zamoli g. episkopa da se primi pretsjedništva.

Kad je bilo izvjesno da će se g. episkop primiti, kandidacioni odbor je predložio ovu listu:

Upravni odbor: Episkop dr. Irinej Đorđević, savj. Đorđe Knežević, g-ca Zorka Skočić, gca Olga Javor, prof. Mirko Ležaić, dr. Tode Novaković (Knin), Tane Kalanj, sreski nadz. 
(Benkovac), Stevo Prostran, Dr. Đoka Malešević, učit. Nikola Manojlović, svešt. Ljubomir Vrcelj, svešt. Pavle Zelić, Milan Budimir (Kistanje), Sava Knežević, težak (Strmica), Gojko Ležaić, težak (Đevrske).

Nadzorni odbor: Dr. Uroš Desnica, dr. Nikola Subotić, prof. Serđe Urukalo, Uroš Dragišić, svešt. Niko Novaković, Lazo Krneta, svešt. Petar Stojsavljević, svešt. Nikanor Kalik.

Episkop Irinej: „(...) Apelujem na sve i svakoga ko ima osjećanja i smisla za opšte interese našeg naroda, naročito na svijesnu i predanu saradnju narodne inteligencije." ${ }^{\text {" }}$

Istovremeno s promjenama u Matici, zbile su se važne promjene u crkvenom ustrojstvu Srpske pravoslavne crkve u Dalmaciji, ali još veće u oblicima udruživanja sveštenstva. Duh korporativizma je bio omniprezentan pa je i Matica sa svojim zadružnim načelima dobila mjesto koje nikako ne bi zasluživala. Istovremeno s promjenama u Matici konstituirane su Konferencija pravoslavnog sveštenstva Eparhije dalmatinske, Privredna zadruga Eparhije dalmatinske, a u skladu s promjenama u Crkvi, konstituirane su Skupština Upravnog savjeta Eparhije dalmatinske i Upravni savjet Eparhije dalmatinske. Glas nije bio iscrpan u prikazivanju rada ovih skupova, ali nije propustio objaviti riječi vladike Irineja s jednog od njih:

Idimo stopama naših slavnih pređa, ali je stidno vječito o njihovom kapitalu živjeti. Ništa nas ne može opravdati, ni školske kvalifikacije, ni hijerarhijski položaj, ni imovno stanje, ni naduveni i prošvercovani društveni ugled, - nego samo istinski napori i bilans stvarnog uspjeha u svim pravcima gdje narod čeka našu pomoć. To je moje mjerilo, to je kriterijum za ocjenu pojedinaca. “68

Bio je to još jedan u nizu vrlo providnih napada na dr. Desnicu kao i druge potentate iz njegova kruga. Cilj je očito bio deligitimirati njega/njih kao političke aktere neovisne o Crkvi. Prividno je paradoksalno bilo da su dr. Desnici kao svjetovnjaku istovremeno bile povjerene dvije ugledne eparhijske časti. ${ }^{69}$ Bio je to, s jedne strane, crkveni odgovor na njegov otpor izboru vladike Irineja za predsjednika Matice, a s druge strane, poruka o tome kako treba usklađivati odnose između Naroda i Crkve.

67 Isto, 3 .

68 Isto, 2. Napadi na „srednji stalež“ i „nenarodnu inteligenciju“ bili su među dalmatinskim Srbima u pojačavani sve do prestanka izlaženja Glasa 1936. godine. Jedan od onih koji se osjećao tangiranim, dr. Boško Malešević iz Šibenika, napisao je pismo koje je Glas objavio: „... nažalost svaki put kad uzmem u ruke 'Glas' moram da ga odbacim s nekim vrlo neugodnim osjećajem. (...) Ali zašto prima 'Glas' takove napise koji raspaljuju zlu krv i kod onih koji su iz dana u dan neopravdano napadani, i kod onih za čije se bajagi interese ovi bore. (...) Taj zlosretni srednji stalež toliko ocrnjivan, a kome je ipak najljepše priznanje odao g. dr. Desnica u svom govoru u senatu, mnogo je toga doprinio i za našu nacionalnu svijest i ekonomski boljitak. Ne smije se zaboraviti njegovo aktivno učestvovanje u svim nacionalnim manifestacijama, prije a i poslije rata, još manje omalovažiti, pogotovo ne prešutiti, njegovu državljansku svijest i građansku lojalnost i trpeljivost u današnjim vremenima. Niko ne može zbrisati njegove humane osjećaje, koje je toliko i toliko puta pokazao, ali opipljivo i zasićeno u tako čestim gladnim godinama baš u tim krajevima." („Dr. Boško Malešević, Šibenik, maja 1934.“, Glas, br. 193, 25. 5. 1934., 3 (ćir.).)

69 „U smislu novog ustava Srpsko-pravoslavne crkve vrši se postepena reorganizacija po svim eparhijama Patrijaršije. U dalmatinskoj Eparhiji novi Ustav je donio samo jedno novo tijelo,... To tijelo je Eparhijski Upravni odbor. Njegova nadležnost je nadzor i uprava crkvene imovine kao i sva materijalna pitanja koja se odnose na život Eparhije. (...) Članovima traje mandat šest godina. Prvi savjet Eparhije dalmatinske održao je svoju skupštinu 16 marta o.g. u episkopskom Dvoru. (...) Savjet se konstituirao ovako: Pretsjednik episkop g. Dr. Irinej Đorđević; potpredsjednik Dr. Uroš Desnica, senator;... Od spomenutih ušli su u Upravni odbor: Episkop g. Dr. Irinej kao pretsjednik; potpredsjednik Dr. Desnica (...)“ („Prva sjednica Upravnog savjeta Eparhije dalmatinske“, Glas, br. 142, 23. 3. 1933., 3 (ćir.).) 


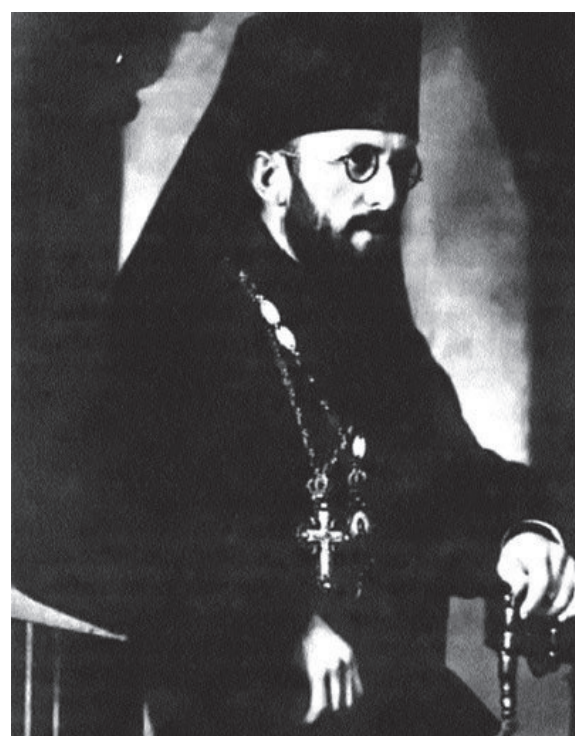

Sl. 3. Vladika dalmatinski dr. Irinej Đorđević, predsjednik Privredno-kulturne Matice za Sjevernu Dalmaciju 1933./1934. godine: s Desnicama protiv Desnica

Sve su to bili refleksi dubinskih previranja u Kraljevini Jugoslaviji i to samo u vladajućem sloju šestosiječanjskog poretka na (sub)regionalnoj razini funkcioniranja, $\mathrm{k}$ tome prije ubojstva kralja Aleksandra I., koji je svojim autoritetom jamčio njezinu kakvu-takvu stabilnost. Time se može objasniti i krajnje nedosljedno ponašanje sve posustalijeg dr. Desnice. Osjećao je da država ide u pogrešnom smjeru, ali je reagirao sve više od situacije do situacije. Ipak nije pristajao biti puki instrument ambicioznih ljudi, neovisno o statusu, za koje je držao da ništa ozbiljno ne znaju ni o svijetu u kojem žive, ni o tome što raditi s državom za koju su bili odgovorni.

Imajući na umu sve ove rascjepe u kojima je 1930-ih živio dr. Desnica, lakše je razumjeti kako je uopće bilo moguće da se pojavi „Jedna izjava iz Sjeverne Dalmacije“.70 Bila je objavljena u Novom dobu, koje je tada bilo mnogo bliže političkoj opoziciji pa i Hrvatskoj seljačkoj stranci nego Jugoslavenskoj nacionalnoj stranci. Novo doba se ipak ogradilo od eventualnih optužbi zbog sudjelovanja u inicijativi: „Zamoljeni od potpisane gospode donosimo slijedeću izjavu..."71 Bilo mu je očigledno u interesu objaviti je jer je najavljivala moguće dublje rascjepe u režimu. Izjavu je potpisala skupina sjevernodalmatinskih dužnosnika, svi srpske nacionalnosti, s dr. Urošem Desnicom, senatorom, na čelu. Bila je usvojena na povjereničkom sastanku u Kninu, „na Usjekovanje 1934.“ 72 Moguće ju je čitati na različite načine. Preraspodjela subregionalne vlasti i moći je jedan od mogućih ključeva. Kažemo mogućih jer ostaje otvoreno već postavljeno pitanje jesu li zaista Privredno-kulturna matica za Sjevernu Dalmaciju i Glas zavrjeđivali javnu pozornost koja im je ovom izjavom bila posvećena ili su Matica i Glas za obje sučeljene strane bili pokriće za izostanak konfrontacije koja je tek trebala uslijediti.

Uvodni dijelovi izjave morali su djelovati zbunjujuće na čitatelje Novog doba jer mnogi vjerojatno nisu ni čuli za Maticu i Glas. Optužbe na granici javne političke denuncijacije nisu nužno morale imati učinka upravo zbog osoba koji su stajale iza izjave:

Potaknuti izvjesnim pojavama u javnom životu Sjeverne Dalmacije, koje su zasada lokalizovane samo na jedan uži krug jednomišljenika i ranijih partijskih drugova i koje nalaze izraza samo u zvaničnom organu društva „Privredno-kulturna matica za Sjevernu Dalmaciju“ no koje ipak mogu da poprime epidemični karakter, naročito kod neukih i neupućenih

\footnotetext{
$\overline{70}$ „Jedna izjava iz Sjeverne Dalmacije“, 11-12 [!].

71 Isto.

72 „...ne žacaju se da svojoj izjavi, na nas upućenoj, dadu značajno ime 'Usjekovanja', kao opomenu na sudbinu Jovanovu, čiju je glavu tražila i dobila razvratna Irodijada, zato što se usudio da javno govori istinu." (Odgovor, 6.)
} 
masa, te da prokopaju jaz između društvenih redova našega naroda u Dalmaciji, potpisani javni radnici, kao legitimisani i odgovorni pretstavnici ovog kraja, nalaze za shodno da iziđu iz dosadašnje rezerve i da pred javnošću dadu ovo OBJAŠNJENJE I DEKLARACIJU (...)

Konkretne optužbe na račun Matičina Glasa jasnije su otkrivale o čemu je riječ, ali nisu puno objašnjavale jer se pojam „ranijih partijskih drugova“ odnosio i na tužitelje i na tužene. Tek posljednji među citiranim ulomcima trebao je čitateljima olakšati razumijevanje „tko je tko“ na protivničkim stranama:

Dana 27 oktobra (1933. - D.R.), „Glas“ iznenada daje znak na uzbunu člankom „Razgovor neugodni" koji, kao po nekom pripremljenom i kombinovanom planu, izazivlje u svakom broju nov članak pun žuči, napadaja, uvreda i sumnjičenja, na varoški elemenat uopće, a na narodne pretstavnike i vođe, poslanike, načelnike i inteligenciju ponaosob.

Počinje se svjesno i sistematski isticati opreka između sela i varoši, naroda i inteligencije, naglasuje se formiranje dvaju frontova, dvaju svjetova i dviju ideologija, ističe se nepomirljivost ovih frontova, svjetova i ideologija, te se, jednom riječju, naviješta klasna borba ali se nikad ne iznose konkretna fakta, nikad se ne formulišu konkretne optužbe i nikad se ne iznose imena grešnika, već se uvijek, nedozvoljenim uopštavanjem, greška jednog imputira cijelom staležu, cijelom mjestu, cijelom društvenom redu.

\section{(...)}

Stil i rječnik postaju mu sve to nepodesniji za tretiranje socijalnih i kulturnih problema, sve to dalji od kulturnih manira i sve to bliži demagoškoj frazeologiji.

(...)

Za inteligenciju se tvrdi da ne može prežaliti Austriju, da nosi austrijske i mletačke tradicije, da mrzi ovu balkansku državu, da joj smrdi šumadinski opanak. Za varoš se tvrdi, da je to onaj drugi front za kojim stoje pauci, karijeriste, kulturni debušanti, nacionalni hipokrite, da služi Mamonu za zdjelu leće itd. Za sebe i svoj front "Glas“ naprotiv tvrdi, da je pionir šumadinstva, da sagorjeva za narod, da poznaje samo jedan pravac (One way only) i slične neozbiljnosti. ${ }^{73}$

Referirajući na više drugih spornih članaka objavljenih u Glasu, potpisnici su zaključak izjave oblikovali kao i početak, tj. na način koji je svojom patetičnošću poticao ambivalentne reakcije:

U saznanju da je ovo pisanje „Glasa“ organa Privredno-kulturne matice za Sjevernu Dalmaciju eminentno sposobno da izazove najveće zlo u našem narodu, da uprlja čast i ugled ljudi koji su veći dio svog života predano i beskorisno služili narodu, državi, plemenu i crkvi, da povrijedi sve forme kulturnog saobraćaja među ljudima, da iskopa provaliju među društvenim redovima, da zavede neuke i povodljive seljačke mase i da raspali bespoštednu klasnu borbu, potpisani se osjećaju prisiljeni ... da se javno desolidarišu od pisanja „Glasa“ ...

Pored dr. Uroša Desnice, potpisnici „Jedne izjave iz Sjeverne Dalmacije“ su: Đuro Vojvodić, proto Sergije Urukalo, dr. Tode Novaković, Boško Desnica, Veljko Pokrajac, Mirko 
Kulišić, dr. Vuk Vujasinović, Milan Urukalo, Obrad Knežević, Aleksa Graovac, Nikola Dragišić, Jovo Šeat, Jovo Perić, Nikola Janković, dr. Jovo Miović, Lazar Krneta, Dušan Miović, dr, Koste Dobrota, Uroš Dragišić, Petar Knežević i Milan Vulinović. ${ }^{74}$

Vladan Desnica nije bio zadovoljan Deklaracijom, sudeći prema stričevoj reakciji. Izgleda da ga je smetalo što se u kritici Matice nisu oglasili i Srbi i Hrvati iz sjeverne Dalmacije, ali i što se davalo maha raznovrsnim zluradostima. Stric je pak bio u pravu tvrdeći da bi uključivanje u izjavu ljudi koji u Matici nisu bili involvirani moglo biti protumačeno kao znak slabosti onih koji su je inicirali. Godila mu je podrška ljudi različitih nacionalnosti nakon njezina objavljivanja:

Ne slažem se sa tvojim nazorima u pogledu deklaracije. Ona je ozbiljna, odmjerena u tonu i dostojanstvena. Ovgje je na nezainteresovane (Dr Filipović, Fra Frane i t.d.) učinila kolosalan učinak. Uvlačenje Kožula, Antunovića i t.d. značilo bi traženje oslona van kruga direktno interesovanih, bilo bi shvaćeno kao znak slabosti i predstavljalo sa naše strane krcanje na brod nepotrebnog balasta. Ovako je otmenije: meo soli che mal accompagnai, a zluradosti bi extra moenia bilo jednako i ovako i onako.

Kad se prigje na pojedinačna razračunavanja onda će se moći pojačati i ton. Ovo je za sada vrlo dobro i na mjestu. ${ }^{75}$

Neovisno o tome što je ona imala svoje ograničene političke ciljeve i što je bila u funkciji subregionalno prepoznatljivih pojedinačnih interesa, bila je i akt otpora etnokonfesionalnim koncentracijama, kako su ih potpisnici shvaćali.

Sinovac nije napisao stricu sve što je imao reći u vezi s objavljivanjem ove izjave. Prešutio je svoje novčane brige u vezi s MSD. Nakon Matičine proljetne godišnje skupštine - poslije svega što se prethodno bilo dogodilo u vezi s časopisom - izostao je javni napad na MSD. Subregionalna distribucija časopisa time nije bila onemogućena. Financijski je to bilo vrlo važno i prvi svezak se izgleda najvećim dijelom bio isplatio. Objavljivanje ove izjave je najavljivalo drugačiji javni i tajni odnos prema $M S D$, što je moglo biti presudno za njegovu budućnost, prije svega s financijskog stajališta. ${ }^{76}$ Vladan Desnica se time još jedanput, kao i na Matičinoj godišnjoj skupštini 1933. godine, našao u položaju koji on sam nije birao.

Odgovor na "Jednu izjavu iz Sjeverne Dalmacije“ objavljen je u Beogradu iste godine u formi brošure, otprilike tri mjeseca kasnije. ${ }^{77}$ Objavljen je kao izdanje Uredništva Glasa Privredno-kulturne matice. Za razliku od „Jedne izjave“, koja je bila tiskana na jednoj i pol strani Novog doba, Odgovor je bio objavljen na 44 tiskane knjižne strane. Za razliku od „Jedne izjave“, komponirane kao „Objašnjenje i deklaracija“, stilski i sadržajno na dva različita načina, Odgovor su činile tri cjeline kojima je zajednički bio vrlo živ, polemičan

\footnotetext{
Isto, 12 .

75 Boško Desnica - Vladanu Desnici, [Obrovac], 17. 9. 1934., OOVD, kut. Prepiska do 1945. I.

76 Karakteristično je s tim u vezi pismo Dušana Korolije iz Bukovice: „Poštovani i dragi gosp[odine] Vlado, od 25 primjeraka Magazina što ste mi poslali uspjelo mi je prodati samo 10 komada za koje Vam danas šaljem 300 Din, a preostalih 15 Magazina vraćam, jer nema izgleda da bi ih mogao prodati. Kako vidite vrlo slabo sam prošao, a prošao bih i gore da nisam davao na vjeresiju. Niko je prošao gore nego ja, jer nije mogao ništa prodati. (...) Uz srdačni pozdrav Vama odani Dušan Korolija“. (Dušan Korolija - Vladanu Desnici, Kistanje, 20. rujna 1935., OOVD, kut. Prepiska do 1945. I.)
} 
i argumentacijski prijemčiv stil, potpuno neovisno o tome koliko su upotrijebljeni argumenti bili kritički održivi. „Jedna izjava“ je bila direktno fokusirana na uredništvo Glasa, a tek indirektno je identificirala vladiku Irineja kao odgovornog za politički neprihvatljivu orijentaciju Glasa i Matice. Njegov vladičanski i osobni integritet nije dovodila u pitanje. Nasuprot tome, Odgovor je adorirao Vladiku i na sve moguće načine diskvalificirao - sve do ruba dijabolizacije - prije svih dr. Uroša Desnicu, potom Boška Desnicu te na kraju i Vladana Desnicu, ali i sve potpisnike „Jedne izjave“ kao „Rođačku zadrugu za iskorišćavanje javnih položaja“. ${ }^{78}$

„Izjava Upravnog odbora Privredno-kulturne Matice za Sjevernu Dalmaciju“ u biti je sažela cijeli Odgovor odnosno apostrofirala dva ključna mjesta. Prvo, dr. Uroš Desnica, dr. Tode Novaković i proto Sergije Urukalo su i sami bili sudionici u donošenju odluka o pitanjima koja su predmet „Jedne izjave“ te su time suodgovorni za stanje u Matici. Posebno su odgovorni što proceduralno nisu iskoristili prava koja su im po društvenim pravilima pripadala nego su spor pretvorili u javni. Točka 5 je osudila pretpostavljene motive njihova ponašanja:

Osuđuje i javne i zakulisne pokušaje koji idu samo za tim da obmanu nadležne faktore i neobaviještenu javnost, da ubace razdor, neslogu i malodušnost među društtvene redove Sjeverne Dalmacije, jer je tim redovima cilj i nasušna potreba međusobna poštena i iskrena saradnja na opštem dobru, a ne gušenje istine i savjesti radi pojedinačnih interesa i povlašćenih položaja. ${ }^{79}$

Drugim riječima, Odgovor je prebacio odgovornost za „razdor, neslogu i malodušnost“ na aktere „Jedne izjave“. S druge strane, točka 6 i cijeli zaključni stav „Izjave Upravnog odbora“ bili su posvećeni obrani osobnog integriteta i deklaraciji o značaju vladike Irineja „na Primorju iza našeg oslobođenja“:

Najodlučnije osuđuje i otvorene i prikrivene napadaje na počasnog pretsjednika naše Matice preosvećenog G. Dra Irineja Đorđevića, koji uživa nepodijeljenu ljubav i duboko poštovanje cijeloga naroda i svih društtvenih redova, bez ikakvih obzira na plemensku i vjersku pripadnost.

Pojava Vladike Irineja, kao pionira istinskog, mučeničkog patriotizma te moralnog, kulturnog i socijalnog preporoda ovdašnjeg naroda, označava jedinstvenu pojavu na Primorju iza

77 „Na to smo štampali u decembru 1934 godine u Beogradu 'Odgovor na jednu izjavu iz Severne Dalmacije', koja je u javnosti poznata kao 'Plava knjiga'." (Severna Dalmacija nekad i sad, 102.)

78 Odgovor čine tri nejednaka dijela: „Izjava Upravnog odbora Privredno-kulturne matice za Sjevernu Dalmaciju“ (3-4), „Odgovor Uredništva Glasa“ (5-37) i „Braća Desnica - i urednik Glasa“ (38-44). „Izjava Upravnog odbora...” od 14. studenog 1934. ima 6 jezgrovito formuliranih točaka. „Odgovor Uredništva Glasa“ je kao kakva pučka čitanka sastavljen iz mnoštva dijelova, napisanih najvećim dijelom po obrascu pitanje-odgovor: „Zašto smo čekali s odgovorom?" (6-7), ,Jesmo li mi 'samo jedan uži krug istomišljenika' ili su oni jedna Rođačka zadruga za iskorišćavanje javnih položaja?“ (7-8), „Jesmo li mi “jedan krug ranijih partijskih drugova??“ (8-9), „Zašto je gospodi trebao istorijat Matice?“ (9-11), „A šta veli šesti broj Glasa?“" (11-13), „Konferencija od 24 decembra 1933 god.“ (14-16), „Ali...“ (16-18), „Godišnja skupština Matice“ (18-19), ,Nedozvoljena uopštavanja““ (19-20), „Jedan niz pitanja“ (20-23) (35 pitanja! - D.R.), ,"Testamenat' bivše Radikalne stranke na Primorju“ (23-28), „Uzgredna napomena“ (28-29), „Naš 'pretsjednik po nuždi'“ (29), „Pitanje Matičina 'Almanaha' ili uloga mladoga Desnice“ (29-34) i „Da se razumijemo“ (34-37). Treći dio „Braća Desnica - i urednik Glasa“ sadržava prepisku između Pavla Zelića, sveštenika i urednika Glasa s dr. Urošem i Boškom Desnicom 19. 4. do 8. 10. 1934., većim dijelom objavljenu u Novom dobu. 
našeg oslobođenja. To je opšte i duboko uvjerenje svih ljudi i faktora koji znaju da cijene ove stvaralačke vrijednosti. ${ }^{80}$

O vladici Irineju se u Odgovoru samo iznimno govori, ustvari najviše u potpoglavlju „Pitanje Matičina 'Almanaha' ili uloga mladoga Desnice“, što je Vladanu Desnici i MSD dalo posebnu težinu u sporovima i konfliktima od 1932. do 1935. godine. Odgovor je inače prije svega predstavljao vladiku Irineja kao osobu koja je svojom duhovnom superiornošću i umijećem javnog djelovanja iznad regula pragmatizma svakodnevice doprinosila rješavanju teških „nacionalnih“ pitanja koja su se desetljećima kumulirala. Drugim riječima, za članove Upravnog odbora Vladika je bio antipod srpskim dalmatinskim potentatima koji su se isključivo bavili onim što im je bilo u interesu i toliko koliko im se to isplatilo.

Ovom prilikom nije potrebno ulaziti u detalje sporova i konflikata koji su markirali uredništvo Vladana Desnice u MSD. „Pitanje Matičina 'Almanaha' ili uloga mladoga Desnice“ (29-34) u Odgovoru predmet je detaljnije rasprave u sljedećem dijelu ovog članka.

\section{MAGAZIN i/ILi ALMANAH SJEVERNE DALMACIJE: Vladan Desnica i Matica}

U svome „novom realizmu“, nakon valova deziluzioniranja u vlastitu „narodnu državu“, prosvijećeni Srbi u Dalmaciji različitih kulturnih i političkih orijentacija dijelili su mišljenje da je i manjini obrazovanih i većini neobrazovanih potrebna periodička publikacija almanaškog i/ili magazinskog tipa otvorena i prema prošlosti i prema sadašnjosti i prema budućnosti vlastite zajednice u regionalnom okruženju. Takva publikacija bila je potrebna i legitimacijski u novoj državnoj zbilji jer su krizne konstelacije koje su odlučujuće utjecale na razvoj društva mijenjale baštinjene političke i kulturne krajolike. Takva nesrazjerno velika težina jedne regionalne periodičke publikacije bila je dakako posljedica društvene nerazvijenosti jedne u sociodemografskom smislu marginalne zajednice.

Njezina marginalnost bila je razmjerno mnogo veća nego u austrijskoj krunovini Dalmaciji. U Kraljevini SHS Dalmacija je izgubila Boku kotorsku, a Srbi u Dalmaciji svoju najvitalniju zajednicu, $\mathrm{k}$ tome i svoj jedini etnički neupitni izlazak na Jadransko more. U austrijskoj krunovini Dalmaciji na prijelazu stoljeća bio je povijesno moguć fenomen Srba katolika, prije svega u Dubrovniku. Koliko god bio situaciono uvjetovan, imao je velik utjecaj na Srbe u Dalmaciji općenito jer je temeljna pretpostavka njegove održivosti bila kultura vjerske trpeljivosti i raznovsnih kulturnih transfera među samim Srbima u Dalmaciji. (Srbi katolici su kao cjelina bili njihov najkulturniji dio u modernizacijskom smislu.) Srbi katolici su uglavnom nestali u Kraljevini SHS. Srpska etnodemografska većina u Dalmaciji živjela je u regionalno nerazvijenima Ravnim kotarima i Bukovici. Istovremeno je ona bila manjina u odnosu spram hrvatske etnodemografske većine u sjevernoj Dalmaciji, tj. u predjelima 
između Zrmanje i Krke te Dinarskog gorja i Jadranskog mora. Gubitkom Zadra nakon 1918. godine, koji je u razvojnom smislu bio mnogo važniji i za Srbe u sjevernoj Dalmaciji nego, primjerice, Knin, moment periferalizacije Srba u Dalmaciji dodatno se pojačao. Dok je za dr. Božidara Petranovića u 19. stoljeću bilo logično nasloviti svoj časopis Srpsko-dalmatinski almanah/magazin jer je Srba bilo u različitim dijelovima Dalmacije, svaki takav pokušaj u 20. stoljeću, točnije nakon stvaranja Kraljevine SHS/Jugoslavije, bio bi nerazuman te politički i kulturno neodrživ. Invalidna sjeverna Dalmacija, Dalmacija bez Zadra i dijela otoka, isto tako je obesmišljavala bilo kakvu etnizaciju sjevernodalmatinske situacije, neovisno o limitima koje je inače nametao oficijelni jugoslavenski integralizam. (Nikome tada nije palo na pamet pokretati Srpsko-sjevernodalmatinski almanah/magazin) Različita politička i kulturna stajališta među Srbima u Dalmaciji vodila su u to vrijeme ka istom zaključku da su legitimnost i prepoznatljivost problematike Srba u (Sjevernoj) Dalmaciji mogući samo ako se s obje nacionalne strane prihvati koncept subregionalno distinktivne Sjeverne Dalmacije kao neotuđivog dijela Dalmacije. Neovisno o tome što je sve motiviralo pojedine utemeljitelje Privredno-kulturne matice za Sjevernu Dalmaciju, najvećim dijelom Srbe po nacionalnosti, ishodište im je $s$ ovog stajališta u početku bilo slično.

$\mathrm{S}$ tog je stajališta u konačnici bilo sasvim nevažno u sukobima u vezi s $M S D$ tko je prvi predložio pokretanje periodičke publikacije almanaškog/magazinskog tipa. U Odgovoru se naročito inzistiralo na prvenstvu Matice:

U samom početku, naime, u projektu svog kulturnog programa, Matica je imala izdavanje „Biblioteke za narod“ i povremeno izdavanje svog „Almanaha“. (...) Prilikom uređivanja vidovdanskog broja „Glasa“ 1929 godine, uredništvu je preteklo više interesantnih priloga, koji nisu mogli dobiti mjesta u listu. Tada sekretar Matice g. Lazar Matić, pismom 7 jula, predlaže ondašnjem uredniku g. St. Prostranu, „da popuni i zaobli preostali materijal novim prilozima i da izda 'Almanah'“. Urednik je odgovorio da on, „pored i onako luđačke prezaposlenosti nije sklon da i taj posao preuzme, sve kad bi i bilo novčanih sretstava za to ". ${ }^{81}$

I tako je pitanje Almanaha praktično bilo skinuto s Matičina programa. Dakle, koliko god svijest o potrebi pokretanja Almanaha kao "povremene“ publikacije postojala u Matici, ona nije prelazila granice spoznaje o ,interesantnim prilozima“ za koje nije bilo mjesta u Glasu. O koncepciji tu nije moglo biti ni riječi. Neovisno o tome što su autori Odgovora htjeli poručiti u vezi s inicijativom Vladana Desnice, ona je bila važna i to mu ide u prilog:

Na misao Almanaha vratio se, početkom 1932 g. Vladan Desnica. Da li samostalno ili u vezi sa već postojećom namjerom Matice - nimalo nije važno. I on je, na svoju ruku i za svoj račun, počeo da piše i da prikuplja priloge od raznih saradnika. Knjiga je po njegovoj zamisli imala da nosi ime „Magazin Sjeverne Dalmacije“, da tako obnovi tradiciju „Srpskodalmatinskog magazina" koji je na Primorju izlazio prije sto godina. Iz njegova docnijeg pisma Matici vidi se, da g. V. Desnica nije bio siguran da će za knjigu naći nakladnika, pa se riješio da je izdaje o svome trošku. No kako su ti troškovi bili veći nego što je on bio voljan da ih sam podnese, g. Desnica se rješava da pozove u pomoć Maticu. ${ }^{82}$ 
Autori Odgovora potom su „preskočili“ daljnji slijed zbivanja sve do Godišnje skupštine Matice u ožujku 1933. godine, dakle cijelo razdoblje dok je predsjednik Upravnog odbora Matice još uvijek bio dr. Uroš Desnica. Vijesti iz Glasa omogućuju nam danas da i njih djelomično rekonstruiramo. Prva je „Književni oglas“ od 11. studenog 1932. godine. Koliko god u njemu bilo ambivalencija, Sekretarijat Matice je očigledno već bio prihvatio inicijativu Vladana Desnice i dao mu u osnovi odriješene ruke, stavljajući njegov posao na istu razinu kao i tematski broj Nove Evrope:

Svršetkom ove godine objavljuju se dvije publikacije iz života i o prilikama Sjeverne Dalmacije.

„Nova Evropa“ izdaje svoj broj posvećen Šibeniku i dalmatinskoj Zagori, a to je većem dijelu Sjeverne Dalmacije.

G. Vladan Desnica preuzeo je na se dužnost, sporazumno sa Sekretarijatom Matice, da uredi jedan Sjeverno-dalmatinski Magazin, sa prilozima književnog, umjetničkog, kulturnog, privrednog značenja - koji se tiču Sjeverne Dalmacije.

Svi oni koji žele surađivati u ovim pitanjima neka se obrate g. Vladanu Desnici u Islam (Ravni Kotari), koji se nalazi na oporavku u svome selu, a ujedno sređuje materijal.

Ovaj Almanah treba da bude vjerna slika naših prilika, ustanova i organizacija i duhovnih težnja i aktivnosti naših ljudi, pa je važno da se oni, koji to osjećaju jave na vrijeme sa svojim prilozima.

Vrijeme i uvjeti izlaženja i raspačavanja javiće se naknadno.

Sekretarijat Matice. ${ }^{83}$

Koncepcija evidentno nije bila usuglašena. Vladan Desnica je imao svoju, koja je u Matici izazivala različite reakcije i implicirala različite zaključke. Njihovim slijedom mogao je to biti i Sjeverno-dalmatinski Magazin, a mogao je biti i Almanah. Mogla je to biti publikacija „sa prilozima književnog, umjetničkog, kulturnog, privrednog značenja - koji se tiču Sjeverne Dalmacije“, a mogla je biti i „vjerna slika naših prilika, ustanova i organizacija i duhovnih težnja i aktivnosti naših ljudi“. Prva je formulacija pretpostavljala izdanje koje će biti znanstvene i književne naravi, a druga izdanje pretežno popularne i informativne naravi.

Oglas je bio objavljen 11. studenog 1932., a publikacija je trebala biti objavljena do konca iste godine! Poziv za suradnju s njime je tek bio otvoren, a „umorni“ mladi urednik, prema Glasu, bio je u selu do kojeg u to doba zbilja nije bilo lako doći. ${ }^{84}$ Neobično je bilo i to što je Sekretarijat Matice, sa sjedištem u Šibeniku, javno bio najavljen kao kolektivni (su) urednik Vladanu Desnici. Izgleda da kritičke reakcije nisu izostale pa se u sljedećem broju Glasa pojavio još jedan književni oglas s istim povodom, ali pod jednoznačnim naslovom Almanah Sjeverne Dalmacije:

83 „Književni oglas“, Glas, br. 133, 11. 11. 1932., 6.

84 Službeno je Vladan Desnica u to vrijeme bio na odsluženju vojnog roka te se ovaj „književni oglas“ može shvatiti i kao politička podvala dr. Urošu Desnici pa i javni podsmijeh Vladanu Desnici zbog nesposobnosti da izdrži tromjesečni vojni rok. 
Kao što smo javili u prošlom broju „Glasa“ g. Vladan Desnica priprema materijal za Almanah, koji će izaći krajem decembra. U njemu će se štampati članci: „Naši ljudi i naše ustanove u prošlosti“, „O publikacijama, časopisima i novinama u Sjever[noj] Dalm[aciji]“, „O Simeunu Končareviću“, „Naše zadužbine i dobrotvori“, o „Morlacima“, „Jedna napoznata buna i jedan neznani mučenik“, "Jedan nov pogled na Dositeja u doba njegovog boravka u Sjev[ernoj] Dalmaciji“, zatim članci o školstvu, o zdravstvu, o sokolstvu, o zadrugarstvu, te nekoliko pjesama i slika iz Sjev[erne] Dalmacije, pored idejnih članaka od naših ljudi, eseja o našim živim ljudima i pomena o našim pokojnicima itd. ${ }^{85}$

U Matici je u međuvremenu, u vrlo kratkom razdoblju, očito bilo prevladalo mišljenje da treba ići na Almanah. Više se nije spominjao bilo kakav dogovor s Vladanom Desnicom s time u vezi. Najavljeni članci svojom većinom najvjerojatnije isto tako nisu bili dogovoreni s njime. Uređivačka politika, implicitna ovoj naknadno objavljenoj najavi, da je bila realizirana, ubrzo bi i Almanah pretvorila u običan Matičin bilten.

Mjesecima nakon toga u Glasu ništa više nije bilo priopćeno u vezi s najavljenom periodičkom publikacijom pa ni u vezi s Vladanom Desnicom. S druge strane, Desničina ostavština svjedoči da je on i dalje djelovao kao urednik. Tek uoči održavanja godišnje skupštine Matice u proljeće 1933. godine Sekretarijat Matice je u Glasu obavijestio javnost o tekućim poslovima pa naveo i sljedeće:

Da se zadovolji prosvjetnim i kulturnim težnjama i obavještenjima već petu godinu Matica izdaje svoj list, g. Vladan Desnica već je sredio sav materijal za Almanah Sjeverne Dalmacije, a naše prilike traže, da se sa izdavanjem knjiga udovolji mnogim specijalnim potrebama Sjeverne Dalmacije. Matica je još u početku počela izdavati nove knjižice svoje biblioteke. ${ }^{86}$

Za razliku od obavijesti iz 1932. godine, kada je bilo riječi i o skorom izlasku publikacije iz tiska, sada se stalo na škrtoj obavijesti da je rukopis pripremljen za tisak. Ni riječi o tome kada bi mogao izaći iz tiska!

Nakon burnoga skupštinskog zasjedanja u ožujku 1933. godine, na kojem je njegov otac predložio samoukidanje Matice i potom se de facto usprotivio izboru vladike Irineja za predsjednika Matice, mladi Desnica se zatekao u nezavidnoj situaciji. Ni u vrijeme predsjedničkog mandata njegova oca ništa nije bilo jednostavno dogovoriti u vezi s periodičkom publikacijom u Matici, kojoj je čak i ime stalno bilo sporno. Nastaviti raditi na istom poslu $s$ osobno povrijeđenim, a vrlo obrazovanim, poduzetnim i autoritativnim Vladikom te $s$ ljudima s kojima je njegov otac svojevremeno stvarao Maticu, a koji su mu u međuvremenu postali ogorčeni protivnici, činilo se praktično nemogućim. ${ }^{87}$ Čini se ipak da je Vladika - analogno odnosu spram njegova oca u vrijeme konstituiranja eparhijskih gremija - prvi reaktualizirao suradnju. Kako drugačije tumačiti to što je u Glasu od br. 155 od 1. srpnja 1933. u nastavcima počeo izlaziti njegov esej "Jedan pogled na ličnost Dositejevu“? Objav-

\footnotetext{
„Almanah Sjeverne Dalmacije“, Glas, br. 134, 1. 12. 1932., 4.

„Pred skupštinu Matice“, Glas, br. 141, 9. 6. 1933., 1 (ćir.).

7 Iznenađuje što se u to vrijeme nije savjetovao ni sa stricem Boškom: „A sad šta je s tobom i s Magazinom. Od jedanput si prestao da mi se javljaš bez ikakva vidljiva uzroka.“ (Boško Desnica - Vladanu Desnici, Obrovac, 18. 6. 1933., OOVD, kut. Prepiska do 1945. I.)
} 
ljivan je do br. 162 od 22. rujna iste Godine ${ }^{88}$ Stric Boško, koji izgleda nije bio čitao rukopis sinovčeva rada, reagirao je euforično već poslije prvog objavljenog nastavka:

Dragi Vladane! Pročitao sam. Na moju riječ vanredno! Nešto što se kod nas rijetko čita. Samo što u Glasu pravi utisak Ćikare Severs u škovaceri. Zašto nisi poslao meni pa da pošaljem Ćurčinu ili u Književni Glasnik? Ovako niko neće ni zapaziti - a to je od Boga grehota. Kad bi bar posebno odštampali, pa da se pošalje Bogdanu Popoviću, Slobodanu Jovanoviću i svim otmenijim duhovima. Grehota da to ostane izgubljeno u suterenu jednog Glasa, jer je stvar klasična! Čestitam ti iz sve duše i ponosim se što imam takvog sinovca. Bravo moj Vladane. Bog te živio! Ljubi te tvoj Barba ${ }^{89}$

Sinovac sigurno nije bio oduševljen stričevim pismom, koliko god mu mogle goditi izrečene pohvale. Nije bio digao ruke od najavljene periodičke publikacije pa ga je morala zasmetati „suterenska“ atribucija Matičina glasila. Bio je to esejistički prvijenac s kojim je „nevjernim Tomama“ u Matici pa i drugima suvereno dokazao da se kritički umije nositi i $s$ najvećim izazovima u kulturnoj baštini i da je sposoban biti urednik izdanja koje je bilo najavljivano kao nasljednik Petranovićeva Srpsko-dalmatinskog magazina.

Objavljivanje „Jednog pogleda na ličnost Dositejevu“ ipak je bila samo epizoda u sve napetijim odnosima između Matičina čelnika, tj. vladike dr. Irineja Đorđevića, Sekretarijata Matice i Uredništva Glasa s Vladanom Desnicom..${ }^{90}$ Kada su nesuglasice ponovno dosegle vrhunac, u ljeto 1933., Vladan Desnica se susreo s Vladikom i o tome nakon sastanka obavijestio svog oca:

Dragi ćaća, (...) U srijedu sam spojio posjetu episkopu sa službenom komisijom. Episkop mi je rekao da je, s teškom mukom, namaknuo sredstva za Almanah i rekao mi da učinim formalni podnesak Matici, facendomi però ben sentire il peso del benefizio. Geriraju se kao da je Matica meni nešto darovala, a ne ja njoj i kaže da se moram osjećati bezgranično počašćen i preplaćen čašću koju mi je Matica učinila „povjerivši“ mi redakciju Almanaha, pa me tako stavljaju vrlo auktoritativno u stav čovjeka kojemu je učinjeno dobročinstvo. Hvala Bogu; una bona lezione. Drago mi je da je ta stvar, kako tako, dokončana, jer volim da moj trud donese bilo kakav rezultat (ovaj put ne samo bez nagrade, nego uz gorčinu i donekle poniženje), nego da pane u vodu. (Rekoše mi da moram moliti da mi prime Almanah i smatrati se sretnim ako ga prime, jer da imaju na pretek rukopisa koji se nude da ih štampaju i kojih bi autori bili sretni kad bi to postigli - to mi je fala što sam - bez koristi i slave - uložio nemali trud i energiju za opću korist.) (...) Ja ću ostati na dopustu do 3 septembra; biću u Plaži. Ako bude što žurne pošte molim te da mi adresiraš: V. D. kod Carića - Jelsa, pa će mi oni proslijediti brevimano. Osobito ako dođe kakav odgovor od Marka Cara molio bih te da mi pošalješ.

Ljubi te tvoj Vladan. ${ }^{91}$

88 Vladan Desnica, „Jedan pogled na ličnost Dositejevu“, Glas, br. 155, 1. 7. 1933., 2-3; br. 156, 13. 7. 1933., 2-3; br. 157, 28. 7. 1933., 2-3; br. 158, 16. 8. 1933., 2-3; br. 159, 31. 8. 1933., 2-3; br. 161, 14. 9. 1933., 2-3; br. 162, 22.9. 1933., 2-4 (ćir. i lat.).

89 Boško Desnica - Vladanu Desnici, Obrovac, 3. 7. 1933., OOVD, kut. Prepiska do 1945. I.

90 Urednik Glasa, proto Prostran, posredno je i Vladanova strica Boška htio uvjeriti da u novonastalim prilikama od časopisa neće biti ništa pa ga je zamolio da jedan od radova napisanih za MSD dade za božićni broj Glasa: „Večeras sam primio pismo od Prostrana u kom me 'kad je oko Glasa' moli da mu za božićni broj pošaljem prilog. Vrijeme je pretjesno da šta napišem, pa mislim da mu pošaljem Šarića Cvijana, ako ti pristaješ i ako ti nije krivo. Odgovori brzojavno." Stričeva reakcija svjedoči da je već bio sklon sumnjati u izlazak časopisa. (Boško Desnica - Vladanu Desnici, [Obrovac, 29. 7. 1933.], OOVD, kut. Prepiska do 1945. I.)

91 Vladan Desnica - dru Urošu Desnici, Split, [?] 8. 1933., OOVD, kut. Prepiska do 1945. I. Ispušteni dijelovi pisma nemaju veze s planiranom publikacijom. 
Budući da Vladan Desnica u svome kolovoškom pismu ocu nije naveo datum sastanka s Vladikom („u srijedu“), zasad je nemoguće pouzdanije rekonstruirati ljetnu kronologiju zbivanja u vezi s časopisom jer autori Odgovora sugeriraju drugačiji redoslijed:

Poslije izmijenjenih nekoliko pisama sa g.g. Matićem i Prostranom, a potom jednog razgovora sa pretsjednikom Matice preosv[eštenim] Vladikom Irinejom, g. Desnica je pismom od 15 jula 1933 god. učinio formalan predlog i molbu, da Matica primi knjigu kao svoje izdanje, pod njegovim uredništvom, i da mu time pomogne bar jednim dijelom troška, ako nema sretstava za sve. A pošto je već imao načelan pristanak pretsjednika, g. Desnica je jednovremeno poslao i prikupljeni materijal na uvid i ocjenu. Rukopisi su bili predati na ocjenu i izvještaj članovima odbora g. prof. Ležaiću i uredniku „Glasa“ proti Prostranu, te je na sjednici od 21 septembra, na osnovu njihova izvještaja, donesen bio zaključak, da se knjiga štampa o Matičinu trošku, pod uredništvom g. Vladana Desnice. ${ }^{92}$

Budući da je autentičnost pisma Vladana Desnice ocu nesporna, neprihvatljiva je tvrdnja autora Odgovora da je on već 15. srpnja te godine „učinio formalan predlog i molbu“ Matici jer je Vladika, prema Desnici, tek na spomenutom sastanku „u srijedu“ ovome rekao da će morati pisati molbu Matici - nota bene, kao da 1932. godine nikakva odluka u vezi s časopisom u Matici nije bila usvojena! Isto je tako nejasno kako je prikupljeni materijal za prvi svezak časopisa predavan Ležaiću i proti Prostranu. Prvo, njih dvojica su već godinu dana bili pregovarali s Desnicom o časopisu i prilozima za časopis. Neke priloge su i sami nudili ili s drugima dogovarali. Očito se štošta presudnog u vezi s časopisom - koji u Matici više nije imao ni šanse dobiti predloženi naziv $M S D$ - rasplitalo ljeta 1933. godine.

Dragocjen bi bio uvid u izvještaj referenata Ležaića i prote Prostrana od 21. rujna 1933. godine. Izvjesno je da je Matica nakon sjednice Upravnog odbora uputila Desnici svoju iscrpnu ocjenu 23. rujna. Na nju se i on pozvao u svom odgovoru od 7. listopada, što se spominje i u Odgovoru. ${ }^{33}$ Ako je Vladan Desnica tom prilikom bio spreman tražiti kompromisne formule, Boško Desnica nije pa je vjerojatno i stričeva reakcija utjecala na ovoga da jasno označi granicu mogućih suglasja:

Što se Almanaha tiče moje je mišljenje da bi Fassung, koju želi da mu dade Matica bila jedna sramota i jedna blamaža i ja nebi želio da se ime Desnica pojavi u jednom pučkoprosvjetnom izdanju. Molim te stoga da budeš nepopustljiv, a u slučaju da Matica ostane nepopustljiva, molim te povuci sve moje stvari, jer i ako nisam Mekole (Macaulay - D.R.) neću da budem ni Jure Kapić. Meni Ćorović dodija tražeći da mu pošaljem što za Priloge a ono bi desetak stvarčica bilo stvoreno za njih. Nemam zašto da ih zakopavam u jednu obskurnu kalendarsku publikaciju, kad mogu da ih izdam u časopisu od velike naučne reputacije, koji, fra le altre, i honorira prostojno. Dunque, ako ne popuste, mandi li par ciavar! Svakako pak zahtjevaj da ugje i Napomena i Pogled na ličnost Dositejevu, jer to i jest jezgro i smisao publikacije. Ako ćemo pisati za kalendare imamo onaj društva Sv. Save i Vardar koji plaćaju. Naši su karonje i každrazi i umrlovi koji još nisu izišli iz periode „Oj, oj, oj, mili rode moj!" Dakle ja ne pristajem i povlačim svoje priloge - to im javi. ${ }^{94}$

92 Odgovor, 31.

93 Isto.

94 Boško Desnica - Vladanu Desnici, Obrovac, 4. 10. 1933., OOVD, kut. Prepiska do 1945. I. 
Kako nema izvornih obavijesti o Vladičinim motivima pri donošenju odluke da iz raznih izvora osobno osigura 20000 dinara za troškove objavljivanja časopisa, s time u vezi zadržat ćemo se na Odgovoru:

Budući da Matica nije imala nikakvih sretstava za ovu svrhu, jer se predviđalo da će trošak prevazići 20.000.- dinara, to je odbor donio svoj gornji zaključak na osnovu izjave pretsjednika Matice, da će se postarati da iz svojih sretstava i priloga svojih ličnih prijatelja izvan Dalmacije osigura potrebitu svotu. U tu svrhu, na polasku u Beograd, uzeo je sobom rukopise da ih pročita, da bi se i sam lično uvjerio o vrijednosti knjige i dobio jačeg poticaja da se kod prijatelja zauzme za stvar. Na povratku iz Beograda pretsjednik je izjavio da se sretstva imaju smatrati osiguranim i tražio da se u zapisnik unese, kako će ovaj novac, kad se ubere natrag od prodaje knjige, imati da ostane kao fond za dalje surhe ove vrste. ${ }^{55}$

Citiranom pasusu smisao daje sljedeći, koji je danas svakako sporan:

Svoju odluku da knjigu izda Matica je vezala za izvjesne uslove koji se odnose na sadržaj knjige i njen raspored, na koje eventualne izmjene ili dopune g. Desnica je načelno unapred pristao pismom od 15 avgusta. ${ }^{96}$

Ovdje se prvi put spominje Desničino pismo Matici od 15. kolovoza. Njegov sadržaj, ako je doista bilo napisano, nije bio ništa drugo nego akt „bezuvjetne predaje“ Desnice Matici. Njegovo kolovoško pismo ocu odavalo je raspoloženje koje nije bilo daleko od rezignacije. Ipak, iz njegova se sadržaja ne može zaključiti da je sin - u žurbi pred odlazak na godišnji odmor u Jelsu, gdje ga je iščekivala njegova zaručnica, buduća supruga Ksenija te ne kazujući ništa o svojim namjerama ocu - napisao to što tvrde autori Odgovora. Oni sami su bili dužni pripremiti izvještaj o rukopisu za rujansku sjednicu Upravnog odbora Matice koja je trebala donijeti odluku o objavljivanju. Zbrka je još veća zato što su Matičini prigovori bili predmet Desničinih komentara u pismu od 7. listopada iste godine. Sadržaj tog pisma isključuje mogućnost postojanja bilo kakva prethodnog u stilu od 15. kolovoza. Stvar postaje nejasnija jer su u nastavku autori Odgovora apostrofirali još jedno Desničino pismo Matici, datirano s 25. kolovozom, koje je imalo drastične implikacije:

Tako, pored neznatnih izmjena u rasporedu materijala, Odbor je doslovno zaključio ovo:

„Da se iz pribranog materijala izostave prilozi: „Napomena“ i „Sintetični pregled“ Vladana Desnice, koje je i on sam već povukao (pismom 25 avgusta); svi dokumenti g. prote Vlačića o unijaćenju; govor u Senatu g. Dr. Uroša Desnice i njegov članak „Problem pravoslavne bogomolje u Splitu“ i prote Urukala "Jedna nepoznata oda Napoleonu“.

Dalje da se „sadržaj popuni time, što bi se pribavili još: jedan članak o našim prosvjetnim i privrednim ustanovama prije rata (prof. Ležaić); da se za nekrolog Jose Mijaljevića pribave od auktora biografski podatci; da se nekrolog Jelene Simić štampa iza g. Ležaićevog članka o njenom ocu grafu Iliji Dede Jankoviću...; da se od g. Lazara Matića pribave članci „O privrednim prilikama u Sjev. Dalmaciji danas“ i „O Privredno-kulturnoj matici“, u koliko ne bi oboje moglo da se smjeste u jednom članku. Uvodnu riječ napisaće pretsjednik Matice, što je i sam prihvatio. ${ }^{\text {"97 }}$

\footnotetext{
95 Odgovor, 30-31.

96 Isto, 31.

97 Isto, 31.
} 
Očigledno su Ležaić i proto Prostran osobno s Desnicom razrješavali najspornija pitanja i prije nego što je Matica službeno zauzela svoj stav o časopisu. Bilo kako bilo, samosvijesni Vladan Desnica našao se doista u stupici. Njegov ranije dogovoreni urednički status pretvorio se u karikaturu. Sve što je učinio podlijegalo je praktično cenzuri zainteresiranih članova Sekretarijata Matice, odnosno Matičina predsjednika, vladike Irineja. Umjesto Vladana Desnice kao urednika uvodnu riječ je trebao napisati Vladika itd., itd. Očevo proročanstvo o klerikalizaciji Matice trebalo se materijalizirati na sudbini njegova sina. ${ }^{98}$

Pismo Vladana Desnice Matici od 7. listopada 1933. godine dragocjeno je prije svega zato što svjedoči da su postojale granice preko kojih mladi Desnica nije prelazio ni onda kada je bio izložen višestrukim pritiscima i rizicima. ${ }^{99}$ Kolovoško pismo ocu sadržavalo je i iskaz koji je bitan za razumijevanje njegovih reakcija u to doba:

Drago mi je da je ta stvar, kako tako, dokončana, jer volim da moj trud donese bilo kakav rezultat (ovaj put ne samo bez nagrade, nego uz gorčinu i donekle poniženje), nego da pane $\mathrm{u}$ vodu. ${ }^{100}$

Odustajanje od jednogodišnjeg, možda i jednoipolgodišnjeg posla za njega jedva da je dolazilo u obzir. Nije htio razočarati svoje najbliže koji su toliko htjeli da s časopisom uspije postati moderni nastavljač dr. Božidara Petranovića i Srpsko-dalmatinskog magazina. Nije htio iznevjeriti one svoje splitske prijatelje $s$ kojima je već tada dijelio umjetničke afinitete te koji su ga dijelom i sami podržali u projektu $M S D$. Nije htio okrenuti leđa nemalom broju vrlo različitih ljudi, s kojima je bio više ili manje blizak i u čijim je očima časopis postao ono što je od početka bio i za samog Vladana Desnicu - njegov svojevrsni vrhunski „ispit zrelosti“. Na koncu, nije htio pokleknuti pred ljudima za koje je bio uvjeren da, neovisno o utjecaju koji su s različitim pokrićima imali, nemaju budućnost zbog svojih retrogradnih uvjerenja i shvaćanja, umjetničke irelevantnosti i kulturne marginalnosti.

Ne ulazeći u detaljniju raspravu o (ne)suglasjima glede (ne)uvrštavanja pojedinih članaka, važno je upozoriti na dosljednu Desničinu obranu kriterija časopisnog razgraničenja znanstvenih od znanstveno-popularnih radova, umjetničkih ostvarenja od amaterskih radova, žurnalističko-publicističkih radova od inovacijskih studija, autentičnih svjedočenja o tradiciji od tradicionalističkog prigodničarstva itd. Njegov naglašeni interes za časopisne rubrike dokaz je koliko mu je bilo stalo da časopis od početka kultivira vlastite kritičke kriterije u svim segmentima sadržaja i da mu od prvog sveska osigura stabilnu formalnu strukturu. Pored načelnih razloga, u tome ga je nesumnjivo ravnalo htijenje da zaštiti svoj urednički status u vođenju uređivačke politike od bilo čije samovolje. Tada mu više ni dvojba „almanah“ vs. „magazin“ više nije bila toliko važna. Bio je spreman do određene granice prihvaćati kompromise, ali nije bio spreman na suštinske koncepcijske uzmake ni zbog časopisa, ali ni zbog samog sebe kao urednika.

98 Svaka usporedba s Petranovićevim Srpsko-dalmatinskim magazinom bila bi već svime navedenim potpuno obesmišljena!

99 Vladan Desnica - Privredno-kulturnoj matici, Split, 7. 10. 1933., OOVD, kut. Magazin Sjeverne Dalmacije. Vidjeti Prilog I.

100 Vladan Desnica - dr. Urošu Desnici, Split, [?] 8. 1933., OOVD, kut. Prepiska do 1945. I. 
Dogovor s Maticom je ovom prilikom došao u pitanje zbog Desničina otvorenog iskazivanja nezadovoljstva njezinim odnosom prema njegovu uredničkom statusu. Autori Odgovora nisu mogli ne iščuđavati se ekplicitnom Desničinu stilu:

Još moram da se osvrnem na neka principijelna pitanja koja su od kapitalne važnosti. (Kursiv je u cijelom ovom navodu naš.)

Ja sam stvorio zamisao Almanaha, ja napravio program rasporeda ... Ja sam bio urednik Almanaha, pa sam ja prosuđivao, prihvaćao ili odbijao priloge. Prema tome, ja sam vršio sve pokretačke i redaktorske funkcije, i tu je, osim mog materijalnog rada, dolazila do upotrebe i moja uviđavnost, kriterij, kakva-takva sprema i t.d. Kao takav ja sam pregovarao s Maticom, i kao s takvim Matica je pregovarala samnom. Kad najednom stvar se potpuno izmijenila: Ja sam postao nešto sasvim drugo. Matičina zamisao, Matičina redakcija, Matičina naklada, a ja sam samo prikupljao priloge. Rečeno bez uvijanja, ja sam postao nešto poput inkasatora, poput onih lica koja obilaze članove društva kakvog da pribiru članarinu. Samo što sam ja mjesto trgovine pribirao pismene sastave ... Matica ni u teoriji, dakle, ne drži da i ja, bar formalno, moram da pregledam priloge koje ona sakupi pa da prosudim da li mogu izići pod mojom odgovornošću ... Iz toga se vidi da se moji pogledi na moj položaj i na moju funkciju, što, naravno, može da čini ozbiljnu zapreku za negocijaciju među nama.

Ostavimo na stranu ovaj stav mladoga g. Desnice, koji je tek jučer školske udžbenike savladao, ....101

Autori Odgovora ni godinu dana kasnije nisu krili razočaranje što je časopis, uvelike prilagođen njihovim zahtjevima, došao u pitanje zbog uredničkog „kaprica“ mladog Desnice. Prema njima, Matica mu je odgovorila pismom od 13. listopada iste godine, ističući „(d) a odbor nije dao nikakva povoda za zaključke koje je g. Desnica izveo, a najmanje je Matica dala povoda za neodgovarajuću intonaciju njegovih primjedaba“. ${ }^{102}$ Budući da je ona tom prilikom ponovila svoj interes za realizaciju časopisnog projekta, Vladan Desnica je smatrao da mora dobiti kakvu-takvu zadovoljštinu da bi suradnja mogla biti nastavljena. U interpretaciji autora Odgovora Matici je 20. listopada uputio pismo sljedećeg sadržaja:

...prihvata daljne primjedbe Matice. Predlaže i ovog puta neke izmjene u rasporedu i želi da se čim prije pristupi poslu. U pogledu tehničke strane napominje, da ona zahtijeva velik, naporan i danguban posao. Ako Matica ne nađe drugi način, on bi bio spreman da to radi, ali uz novčanu oštetu kakvu Matica nađe za shodno da mu se odredi. ${ }^{103}$

Na to je Matica odgovorila 26. listopada:

.... što se tiče tehničke strane, Matica preuzima sve na sebe, samo da se prištedi na sretststvima. ...Vladika Dr. Irinej je prihvatio, da će on sam po potrebi noću vršiti korekture čitave knjige, ako drugi članovi nemaju za to vremena, budući da su svi prezauzeti poslovima, kao i on sam. (...) Ovom prilikom poslana je g. Desnici opširna, vrlo lijepo izrađena i dokumentovana studija g. prof. Ležaića o našim kulturnim i privrednim naporima prije rata, koja je bila na odborskoj sjednici pročitana i prihvaćena. ${ }^{104}$

\footnotetext{
01 Odgovor, 32. Vidjeti Prilog I.

102 Odgovor, 32.

103 Isto. Kurziv autora Odgovora.

104 Isto, 32-33. Kurziv autora Odgovora.
} 


\title{
Поштовани господине,
}

о Божићу ће изићи из штампе књига »Магазик Сјеверме Далмачијещ. Намјену, сврху и потребу овакове књиге најбоље ће протумачити предговор који ће бити штампан пред текстом, па га доносимо у цјелини:

\begin{abstract}
Пред читав један вијек далматински су Срби имали своју годишњу публикашију „Србскодалматински алманах«, каснији „Србско-далматински магазин«.

Дакле већ у оно доба, у онако тешким животним приликама и условима развитка, наш јавни живот био је тако интензиван, а интерес за јавна питања тако жив, да је из потребе никнула једна годишња културна ревија.

Одонда до данас наш јавни живот и наша културна продукшија стално су расли и развијали се, а наш прилог опћој југословенској. мисли и јүгословенској књизи постајао је све већи и све знауај. нији. Према томе, ова наша културна публикашија, која наставља традицију »Србско-далматинског Магазина«, данас има тим јаче оправдање и тим ширу задаћу.

Живот овога краја, пегове потребе и његове духовне тежње, бар у приншипу, једнако су важни као и живот, потребе и тежње ма којег другог краја. Али су оне, из разних узрока, мање видне и мање уважаване. - „Магазин« има да буде преглед нашег јавног живота, наших прилика и потреба и мање уважаване. - „Магазини има да буде преглед нашег јав

Наши су јавни радници расијани по читавој држави и дјелују у разним срединама, па се заборавља да су сви они синови јелног краја и носиоци једне културне традиције; њихов се рад, узет као цјелина, нема у виду и недовољно се хонорира. $-\mathrm{Y}$ „Магазинуж ће они имати прилике да наступе заједно, повезани припадношћу истој средини.

Напокон, „Магазин« је поставио себи за задаћу и то, да обрађује нашу прошлост, која је коликогод непозната толико и свијетла, - Зато ће публиковати документе из наше прошлости и доносити историске радње.

За поједина питања од веће важности са подручја културне историје, политичке историје квнжевности итд., која нису довољно расвијетљена ни обрађена, „Магазнн« ће отворити сталне рубрике, у којима ће доносити документе, изворе, вијести, радње и уопће све што се на то односи, да тако прибере градиво и облакша рад онима који би хтјели да та питања исирпно и систематски да тако

Вршење ових задатака задовољиће духовне потребе једнога краја, а и за цјелину ће значити несумњиву добит.
\end{abstract}

Књигу је уредио r. Владан Десница, а сарађивали су махом наши истакнутији људи, признати и цијењени на виховим пољима рада, па је у њој наш крај дошао - по први пут - до свог пуног и најбољег изражаја. Ова је књига преглед наших вреднота, биланс нашега рада и оглед наших снага. Материјал је подијељен на три дијела: 1) Историја, 2) Књижевност, 3) Наши проблеми.

Познавајући Вашу заузетност и Ваш рад за бољитак и напредак нашега краја, увјерени смо да ћете увидјети корисност и потребу овакове књиге, па да ћете је својски подупријети и пропагирати. Зато Вас именујемо повјереником и молимо Вас да нам у Вашем мјесту и околици, међу Вашим пријатељима и познаницима скупите што већи број претплатника, јер ћете тако потпомоћи овај напор да се оснује једна наша годишња културна публикација. Књига ће обухватати 180 - 200 страна великог формата, 6 иће солидно и укусно опремљена, са више добрих илустрација у тексту. Цијена јој је у претплати Дин 30.-, док ће ван претплате бити знатно скупља. Молимо Вас да нам јавите имена претплатника на адресу: Владан Десница, Сплит, Сињска ул. 7, а уплаћени новац да нам пошаљете приложеним чеком. Чим књига изиђе, биће у првом реду разаслана претплатницима, о нашем трошку. Требало би да нам имена претплатника и уплаһени новац стигну чим прије, најдаље до 20 депембр да узмогнемо према томе одредити тиражу књиге.

С пуним поуздањем у Вашу помоћ и заузетност,

с одличним поштовањем

Уреомиนтво »МАГАЗИНА《

Sl. 4. „... Bo Božiću će izaći iz štampe Magazin Sjeverne Dalmacije.“ Okružnica Vladana Desnice upućena potencijalnim povjerenicima Magazina iz studenog 1933. godine.

Vladan Desnica vjerojatno ni u snu nije bio pomislio da bi vladika Irinej, koji je u ratnom Londonu jedno vrijeme vodio Pres-biro srpske Vlade, bio spreman preuzeti poslove tehničkog/izvršnog urednika. Da jeste, vjerojatno ne bi ni otvarao ovo pitanje. Vladika, koji se u međuvremenu bio toliko založio osigurati potrebnih 20000 dinara - poprilična suma u 1930-im godinama - i koji je pitanje Almanaha očigledno doživljavao legitimacijski, a još više prestižno vrlo važnim te je iskoristio zahtjev Vladana Desnice da mu „očita“ lekciju iz skromnosti i samopožrtvovnosti. Prema autorima Odgovora, ovaj više nije ni pisao Matici:

Ali sad dolazi ono što nas je sviju zgranulo. Ravno poslije mjesec dana ćutanja, naime 26 novembra g. Desnica, bez ijedne riječi Matici, piše pismo jednom članu Matičina odbora, u ko- 


\section{МАГ АЗИН \\ СЈЕВЕРНЕ ДАЛМАЦИЈЕ}

1934.

УРЕДИО

ВААДАН ДЕСНИША

ХPBATCKA IITAMIIPHJA C. ВИДОВИҢ - CПАНT

Sl. 5. Naslovnica Desničina Magazina Sjeverne

Dalmacije 1934., tiskanog u splitskoj Hrvatskoj štampariji S. Vidović

me mu javlja da je „napokon $i$ ako s malim zakašnjenjem - oživotvoren magazin, onako kako ga bio u početku zamislio“... „Osnovao sam jednu regionalnu istorijsko-literarnu godišnju reviju“ za koju je, veli, uzeo materijal koji mu za tu svrhu odgovara, dok preostalo gradivo prepušta Matici za njen „Almanah". U pismu šalje i štampani oglas o svojoj knjizi i čekovnu uplatnicu za pretplatu. I pošto je to uradio, g. Desnica, pismom od 29 novembra, predlaže Matici da se materijal podijeli na dvoje: jedan dio da posluži njegovoj literarno-istorijskoj reviji, a drugi „prosvjetnoj i popularizatorskoj misiji matičinoj“. On će izdati svoju reviju, a Matica neka izda svoju publikaciju. ${ }^{105}$

Odgovor je zasad jedini izvor koji svjedoči o dramatičnom raspletu slučaja $\mathrm{Al}$ manah/Magazin Sjeverne Dalmacije te ovom prilikom nema smisla hipotetički provjeravati održivost daljnjih formulacija u ovoj polemičkoj brošuri s tim u vezi.

Kronološki se podudaraju sa svime što je s Desničine strane tada bilo poduzeto da prvi svezak Magazina Sjeverne Dalmacije bude objavljen prije proljeća 1934. godine. O tome će ovdje biti više riječi. Prema autorima Odgovora Matica je reagirala na sljedeći način:

Budući da odbor nije mogao da rješava o predlogu koji je g. Desnica već izveo, to je Matica imala samo da utvrdi činjenicu i da predmet skine s dnevnog reda, što je i učinila na sjednici od 15 decembra 1933 godine, kvalifikujući - jednoglasno - ovaj postupak g. Desnice kao „krajnje nelojalan i nekorektan“ jer g. Desnica nije nimalo vodio računa o ozbiljnosti foruma koji mu je učinio pažnju da s njime sarađuje, a posebno nije vodio računa o ličnosti preosvećenog g. episkopa Irineja, koji se lično bio, sa krajnjim požrtvovanjem, založio za što bolji uspjeh Almanaha kao jednog preduzeća koje košta novaca, a koje je po zamisli g. pretsjednika imalo ostati kao trajna naša tekovina. (...) Izrazivši, dalje, preosvećenom g. Episkopu blagodarnost na njegovu trudu i zauzimanju oko ovog i drugih naših poslova i briga, odbor je konstatovao „da je g. Desnica upropastio jedno djelo koje je Matica zamislila i propagirala. Mjesto da se nademo svi zajedno i da se ne dijelimo, da izađemo sa Almanahom kao vjernom slikom naših prilika i potreba, g. Desnica je naročito htio da podijeli naše društvo kao izabrano i prosto - na elitu i na "puk“ (zap. 15 decembra 1933). ${ }^{106}$

Umjesto tadašnje, upravo iz Matice zagovarane podjele Srba u Dalmaciji na one „šumadijskog“ i na one „prečanskog“ duha, a inteligencije na „narodnu“ i „tuđinsku“ itd., 
za ovu je priliku bila reaktualizirana ranija podjela na „elitu“ i „puk“. Vladan Desnica je bio prokazan kao elitist, što je u tadašnjoj korporativistički usmjerenoj političkoj kulturi imalo pežorativno individualističko, dekadentno značenje. Desničin vjerojatni iskaz „Osnovao sam jednu regionalnu istorijsko-literarnu godišnju reviju..." dodatno je morao razdražiti duhove jer je sugerirao koncepciju koja praktično ničega više nije imala zajedničkog čak ni sa Srpsko-dalmatinskim magazinom dr. Božidara Petranovića.

Prvi svezak MSD tiskan je prije Matičine godišnje skupštine u proljeće 1934. godine. Kada je to točno bilo, zasad nije moguće reći. ${ }^{107}$

Vladan Desnica, poučen iskustvom iz 1932., prihvatio je stričev prijedlog da se objavljivanje odloži za početak 1934.:

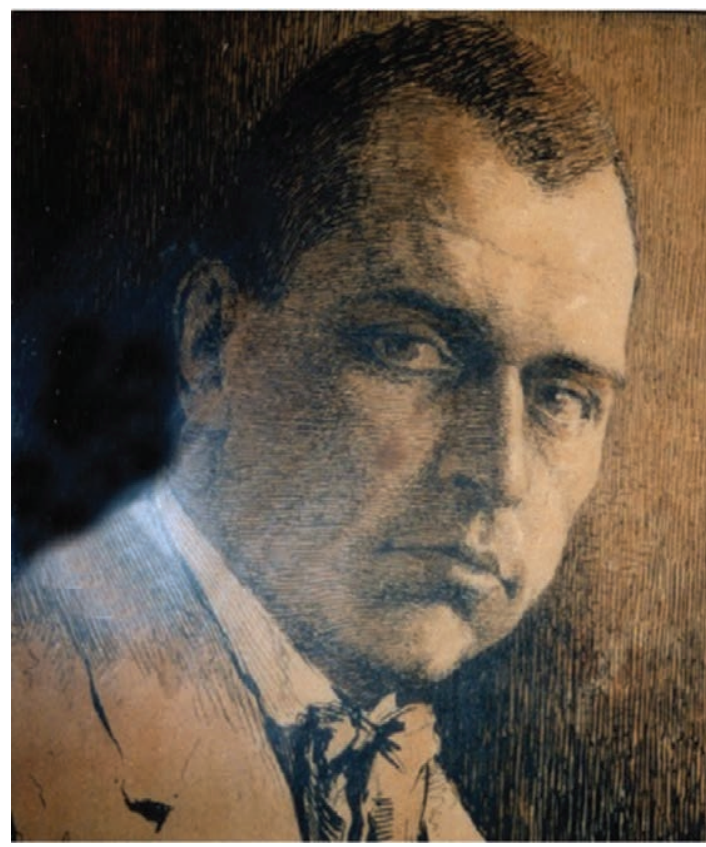

Sl. 6. Boško Desnica, Vladanov stric i duhovni „alter-ego"

Pošto Almanah (bolje i radi tradicije Magazin) nije prešan jer nema veze s kalendarom, molim te odgodi do Januara. To je sveti mjesec u kom se ne kriču rasprave. Nastojaću da te, u koliko mognem, zadovoljim iako bi stvar o Morlacima, kako je ti zamišljaš, bila za Cvijića ili Erdeljanovića a ne za mene analfabetu u etnografiji a poluanalfabetu u istoriji: mi son un Sobalich e no un Brunelli. Dakle, riveputemo per gennaio. ${ }^{108}$

$\overline{107}$ Sačuvana prepiska sa stricem svjedočanstvo je o vremenskom tjesnacu u kojem se Vladan bio zatekao htijući objaviti MSD u 1933. godini. Različite su teškoće bile u pitanju. Iako to eksplicitno nigdje nije bilo rečeno, uvršteni radovi u načelu nisu smjeli biti prethodno objavljivani. Koncepcijski ga je to kao urednika suočilo s ozbiljnim teškoćama. Da bi prvi svezak u svome historiografskom dijelu bio dovoljno reprezentativan, nije mogao biti kompletiran bez stričevih radova. On je bio neupitan autoritet za „morlačku“ povijest Ravnih kotara i Bukovice, ali nije mogao napisati sve što je Vladan od njega očekivao. Pretiskivanje nekih njegovih manjih, tematskih važnih, radova time je postalo neizbježno. Boška je to ljutilo jer je znao kakve će reakcije time izazvati: „Odgovaram ti odma: 'Priloge’ treba štampati kao jednu jedinstvenu radnju pod općim naslovom, a pojedine člančiće sa njihovim podnaslovima apsolutno kronološkim redom. Hoćeš li tretirati smrt Stojanovu kao dio priloga ili kao posebnu radnju - to ostavljam tebi na volju. One druge otužnosti, koje si se kapricirao da preštampaš svrstaj iza Priloga, ali takogjer kronološki. Na tvoju želju šaljem ti Sarića, ali mi se čini da si prećerao, pa se bojim da ti se zamjeri da bi Magazinu bolje pristajao naslov 'Sabrane pizdarije B[oška] D[esnice]' ili 'Album porodice Desnica'، (Boško Desnica - Vladanu Desnici, Obrovac, 15. 12. 1933., OOVD, kut. Prepiska do 1945. I.) Iz tog razdoblja potječe i Boškovo pismo glede priloga „Jedna nepoznata buna i jedan neznani mučenik“, o buni tradicijski poznatoj po popu Petru Jagodiću Kuridži, parohu iz Biovičina sela. Bio je to ranije objavljeni tekst, koji je iziskivao temeljitu preradu. Kako ni to nije bilo izvedivo, a Vladan nije popuštao, Boško je „planuo“: „Dragi Vlade! Prihvatio sam se prerade prokletog Kuridže i nailazim na teškoće, jer je nemoguće složiti opreke zvaničnog izvještaja i njegove verzije. Kako bi bilo napustiti potpuno prikaz i publicirati sama gola akta, (kao zadnji član one serije) pa nek svak tumači stvar po svom ukusu? Odgovori mi odma." (Boško Desnica - Vladanu Desnici, Obrovac, [?] [?] 1933., OOVD, kut. Prepiska do 1945. I.) Prerađeni članak objavljen je ipak u MSD tek 1935. Vidjeti Boško DesnicA, „Jedna nepoznata buna i jedan neznani mučenik“, MSD, 2/1935., 47-57 (ćir.).

108 Boško Desnica - Vladanu Desnici, Obrovac, [konac 1933.], OOVD, kut. Prepiska do 1945. I. 


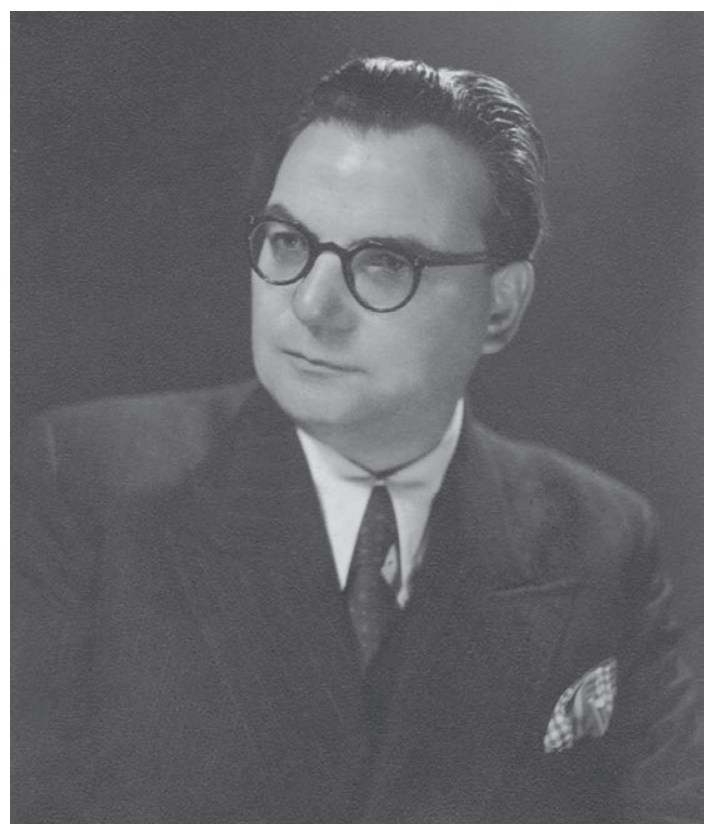

Sl. 7. Dr. Grga Novak i historiografska pohvala Obrovčanima 1848. godine u akciji za sjedinjenje Kraljevina Hrvatske, Slavonije i Dalmacije (Magazin Sjeverne Dalmacije 1935.)
Godišnja skupština Matice u proljeće 1934. godine nije raspravljala o časopisu. Optimističku najavu iz Glasa u proljeće zamijenila je krajnje evazivna formulacija koja je suprimirala buru:

Sekretar Matice i urednik „Glasa“ g. Stevo Prostran izvjestio je o radu odbora, o društvenom organu i o društvenoj blagajni. (...) Na sjednicama, pored tekućih pitanja, rješavano je i pitanje „Almanaha“, o čemu će „Glas" posebno izvijestiti, i pitanje pravca pisanja i uređivanja „Glasa“, o čemu je „Glas“ već izvijestio. ${ }^{109}$

Prema autorima Odgovora, stvar je stajala drugačije:

Ovdje nije bez interesa napomenuti, kako je godišnji izvještaj Matice na skupštini od 15 marta 1934 obuhvatio i ovaj predmet. Učesnici se sjećaju kako su bili revoltirani ovim postupkom i kako su pali odlučni predlozi da se o ovom povede diskusija i donese osuda skupštine, ali se na izričitu molbu preosv[eštenog] g. pretsjednika od diskusije i ma kakvih zaključaka odustalo. I ovakav postupak s naše strane naziva se nelojalnom borbom i cijepanjem naših redova na klase! ${ }^{10}$

Na kraju su se autori Odgovora vratili na početak i ponovili optužbu da je časopis trebao osigurati pretpostavke za politički uspon Vladana Desnice do razine na kojoj je bio njegov otac. ${ }^{111}$ To je i bio razlog što su autori Odgovora smatrali potrebnim u svome obračunu s dr. Urošom Desnicom obračunati se i s njegovim sinom Vladanom Desnicom, izričući i svoju zaključnu ocjenu:

Almanah je trebao da bude prvi javni „debi“, prvi nastup mladoga g. Desnice na našu društvenu pozornicu. Dok se radilo o tome da Matica plati režiju za prvu njegovu ulogu dotle je mladi g. Desnica sa Maticom pregovarao, a kad se g. otac postarao za sretstva izvan Ma-

109 „Sa godišnje skupštine 'Privredno-kult[urne] Matice“", Glas, br. 185, 24. 3. 1934., 1 (ćir.). U raspravi o kulturnoj politici Matice Gojko Ležaić je pored ostalog rekao: „Pretsjednik naše Matice napojiće našu inteligenciju i naš narod duhom narodne kulture Srbije, od koje smo mi pregrađeni visokim zidom 'prečanske' kulture, koja je pritisla narod kao mrtvačka ploča, jer je ispunjena sa tuđinskim duhom." (Isto, 2.) U takvu ozračju Desničinu MSD jednostavno više nije bilo mjesta, tim više što su se iz mjeseca u mjesec u Glasu pojačavali slični tonovi: „...kod nas postoje dva mentaliteta, dva osnovna pogleda na materijalne i duhovne vrijednosti na kojima počiva istorijska sudbina našeg naroda. (...)“ („K sebi ruke i - na se glavu!“, Glas, br. 200, 1. 8. 1934., 1 (ćir.).) U glavama urednika Glasa su „šumadijsko-prečanske“ kulturne razdijelnice među Srbima u Dalmaciji postale linije bojišnice: „Optužuju nas da bunimo narod i da hoćemo da uvedemo duh Šumadije i kod nas, gdje je narod drukčije vaspitan, u pitomim kulturnim državama sretne i nezaboravne prošlosti. Ali, misle, još ima nade da tekovine kulture i civilizacije neće propasti pred naletom balkanskih varvara.“" (Naši grijesi“, Glas, br. 201, 22. 8. 1934., 1 (ćir.).)

110 Odgovor, 33.

111 Odgovor, 34. 
tice, koja su djelomično pala i na teret opštinskih blagajna, koje su u rukama rođačke zadruge, onda je g. Vladan Desnica došao na misao: da bi bila velika šteta za njegovu buduću javnu karijeru i prestiž njegove porodice, kad bi „Almanah“, koji je po uvjerenju njegova oca „najbolja knjiga koja se poslije rata kod nas pojavila“, bio razvodnjen sa „prosvjetnim $i$ popularizatorskim" clancima P[rivredno] K[ulturne] Matice, namjenjenim svim slojevima našeg društva. ${ }^{112}$

Nakon što je objavljen prvi svezak MSD, očekivalo se da će Matica objaviti i svoj Almanah. Boško Desnica za zanimao za vijesti s time u vezi u dobru raspoloženju nakon objavljivanja $M S D$, ali i u brizi za „ekonomske efekte“ poduhvata koji je izgleda poprilično stajao:

Čudnovato mi je da niko ne spominje Almanah. One su tvoje 3 lirike rijetko lijepe. Brace zna prve dvije na pamet. Imam od Mag[azina] 90 D. a 30 imam još da primim. Čekam i to pa da ti pošaljem sve skupa. Kakav je uopće bio ekonomski efekat? ${ }^{113}$

Ni prvi, kao ni drugi realizirani svezak $M S D$, dakle, nemaju nikakve veze s Privrednokulturnom maticom za Sjevernu Dalmaciju. Naprotiv. U konačnici su nastali nasuprot Matici. U oba stoji na str. 1 da ih je uredio Vladan Desnica te da ih je tiskala „Hrvatska štamparija S. Vidović - Split“. Obje su unutrašnje naslovne strane kao i prednje korice tiskane ćirilicom.

Nakon objavljivanja prvog sveska $M S D$ izgleda da je Vladan Desnica odlučio dići ruke od daljnjeg uređivanja časopisa. U stričevu pismu od 24. srpnja 1934. godine doslovno stoji:

Što se tiče redakcije vtor[og] dijela ja ću je rado izvršiti, ali hoću da ti ostaneš i nadalje titularni redaktor svega. Ne radi straha od odgovornosti već stoga što je Mag[azin] tvoje djelo, vezan za tebe, što tebi ima da zahvali za uspjeh prve knjige pa neću nikako da se odvaja od tvog imena i krnji ta jedinstvenost. Nek se sve šalje na tebe a ti šalji meni. ${ }^{114}$

Daljnja njihova prepiska svjedoči da je Vladan ipak odustao od svoje odluke da uredništvo de facto prepusti stricu. Naprotiv, budući da je drugi svezak po svojim prilozima bio izrazito „litoraliziran“, teško da to nije bila Vladanova koncepcija, neovisno o tome koliko ju je dogovarao sa stricem.

Time je bio napravljen sadržajni pomak od „morlačke“ k „bodulskoj“ Sjevernoj Dalmaciji te velikim dijelom od ruralne $\mathrm{k}$ urbanoj i, dijelom od svakovrsnih pučana k izobraženima i stvaraocima. Očigledna je bila namjera kompletirati inter- i transkulturnu sliku Sjeverne Dalmacije iz oba njezina horizonta. Međutim, popustao je i stric, uputivši jedno ljudski neuobičajeno pismo u 20. stoljeću, baš kao „romantik“ tog vijeka. ${ }^{115}$

\footnotetext{
$\overline{112}$ Isto. „Taj se postupak sa Maticom mladom g. Desnici učinio toliko prirodan, da se je čak uvrijedio kad su mu poslije saradnici iz Matičina Odbora otkazali saradnju i povukli svoje rukopise, čime je njegova knjiga izgubila deset priloga, koji su čak i njegov urednički ukus zadovoljili.“ (Isto.) Sudeći prema poznatim naslovima povučenih članaka, a znajući tko su njihovi autori, izgleda da se pod spomenutim naslovom Severna Dalmacija nekad $i$ sad, objavljenim u Beogradu 1939. godine, „krije“ nesuđeni Matičin Almanah. Budući da su i Matica i Glas prestali djelovati/izlaziti 1936. godine, ovo izdanje se moralo pojaviti pod drugačijim naslovom, koji je ipak sadržavao i „S(j)evernu Dalmaciju“ i „nekad i sad“.

113 Boško Desnica - Vladanu Desnici, Obrovac, 11. 3. 1934., OOVD, kut. Prepiska do 1945. I.

114 Boško Desnica - Vladanu Desnici, Karin, 24. 7. 1934., OOVD, Prepiska do 1945. I.

115 Vidjeti Prilog II.
} 


\section{JOŠ JEDAN DESNIČIN NEUSPJEH U TRAŽENJU IZLAZA I933. GODINE ILI KAKO POSTATI STALNI SPLITSKI DOPISNIK BeOgradske POLITIKE?}

Pripravnički posao u državnoj službi i silne tjeskobne neizvjesnosti u vezi s periodikom u vrijeme kada je izgarao od potrebe da umjetnički stvara sve više su ga dekuražirali pa je u jesen 1933. godine - nakon što je načuo da bi beogradska Politika htjela imati novoga stalnog dopisnika iz Splita - poduzeo sve što je mogao da to mjesto i dobije. Nema sačuvanih dokaza da ga je otac u tome naumu podržavao - teško da bi to uopće odobrio, da je za to znao - ali stic Boško, koji je povremeno surađivao u Politici, jeste i to svesrdno. Već u svome prvom pismu na tu temu, koju je otvorio Vladan, reagirao je na granici euforije. Obećao mu je pisati izravno Vladislavu Ribnikaru, „gromovniku“ u Politici.

Boško Desnica nije propustio idealnu priliku usput podijeliti svome sinovcu nekoliko jezično-stilskih savjeta, koji otkrivaju da je mladi Desnica jezično bio daleko od „beogradskog stila“. Doduše, sudeći prema jeziku i stilu stričeva pisma, ovaj je bio još dalje:

...ako ti hoćeš, mi ciappo el corragio a due man i pišem ravno gromovniku Ribnikaru. Za taj slučaj trebam par tvojih štampanih stvari da ih pošaljem ka muštru tvog pisanja. Ali ako budeš pisao za Politiku, trebaće da dadeš jeziku jedan pravoslavniji pečat i da opereš i tuoi cenci nella Sava, o possibilmente nel Vardar pri čemu će ižmariti oni pusti „dojmovi“ i drugi ne ortodoxni izrazi. Dunque, mišu moj, pošalji mi to što tražim e rimettite all'avvedutezza tvog slavnog barbe, koji te razumije i štimava i voli. ${ }^{116}$

Dva dana kasnije, 4. listopada, Boško se sjetio da je Vladanov otac, Uroš, blizak s moćnim Stanojem Stanojevićem, čovjekom velikog utjecaja i u Politici:

Sad mi pada na pamet da je ćaća vrlo prisan sa Stanojem Stanojevićem a da je ovaj ninfa Egeria Politike i da je ona za dobar dio njegovo vlasništvo. Dobro bi bilo da on preduzme 'un azione fiancheggiante' kod Stanoja koja će poduprijeti moj frontalni napad na Ribnikara. ${ }^{117}$

Čim je od Vladana primio tražene rukopise, Boško je poslao ekspresno pismo Vladislavu Ribnikaru. ${ }^{118}$ Kopiju je uputio Vladanu.

Obratio se Ribnikaru s poštovanjem, ali bez snishodljivosti, srdačno: „Sjećajući se ljubazne susretljivosti na koju sam kod Vas naišao u nekoliko prilika, slobodan sam da Vas zamolim za Vašu pomoć u jednom poslu, koji mi mnogo leži na srcu. ${ }^{\text {“119 }} \mathrm{Na}$ propuštajući napomenuti da je Vladan sin senatora dr. Uroša Desnice, ključni dio svoje preporuke sažeo je na sljedeći način:

\footnotetext{
116 Boško Desnica - Vladanu Desnici, Obrovac, 2. 10. 1933., OOVD, kut. Prepiska do 1945. I.

117 Boško Desnica - Vladanu Desnici, Obrovac, 4. 10. 1933., OOVD, kut. Prepiska do 1945. I.

118 Boško Desnica - Vladislavu Ribnikaru, Obrovac, 15. 10. 1933., OOVD, kut. Prepiska do 1945. I. Vladanu je poslao kopiju pisma. Inače, Boškova prepiska s Vladanom, koliko je sačuvana, sva je na latinici. Pismo Ribnikaru je na ćirilici.

119 Isto.
} 
Neskromno je da ja ističem pozitivne kvalitete čovjeka, koji mi je toliko blizak, pa mjesto toga prilažem nekoliko njegovih napisa, koji će Vam dati mjeru tih osobina. Molim Vas da budete ljubazni pa da ove priloge, naročito radnju o Dositeju, pažljivo pročitate. Ako po tom nađete da mladi čovjek, koji je ovako prozreo i prikazao intimnu bit Dositejeve ličnosti, subjektivno, po svojoj realnoj vrijednosti zaslužuje da se ubroji među članove Politikine porodice, tad Vas molim da upotrebite svoj veliki upliv, da ponuda, koju je on upravio redakciji bude prihvaćena. ${ }^{120}$

U sačuvanoj ostavštini Vladana Desnice nema nikakvih tragova o Ribnikarovoj reakciji. Međutim, Vladanovu kandidaturu je izravno, u komunikaciji s Ribnikarom, podržao i slikar Ignjat Job, s kojim se - sudeći prema sačuvanim pismima - dobro poznavao. Pismo vrijedi u cijelosti citirati:

\section{Dragi gosparu Vladane,}

maločas sam bio kod direktora „Politike“ g. Ribnikara i s njime o onoj stvari razgovarao najpredanije. On je stvar primio dobro i kazao mi da Vašu ponudu (kao stalni dopisnik) uputite na adresu: g. Dobroslav Kuzmić, suradnik „Politike“, Poenkareova 31. Posao dopisnika stvar je naime toga gospodina, a on će referisati njemu, direktoru. No stvar se definitivno ne bi mogla urediti, dok g. Kuzmić ne dođe u Split da valjda likvidira sa starim dopisnikom i da $\underline{s \text { Vama razgovara. }}$

To da s Vama razgovara, kazao mi je g. Ribnikar, dakle, kako izgleda, on to misli da primi (što bi ja od svega srca želio), samo kaže ne može da rekne kad će to biti, tj. tačno. Naime kad će ovaj u Split.

Ja ništa na svijetu ne vjerujem dok ne vidim svojim rođenim očima, ali ovako izgleda dobro. Ja sam uostalom i na drugoj strani poradio. Križanić će da toga Kuzmića malo porazgovori i t.d. Nadati se je, što rekli Rvati. Samo molim Vas nikome ni riječi da sam se ja na ikakvoj formi u to umiješao. Razgovaraćemo uostalome, jer ja ću kroz koji dan dolje. Sa zdravljem mi je znatno bolje. Tu ponudu svakako uputite odmah. Ćirilicom.

Pozdravite gospara papu i sve naše.

Živjeli u zdravlju!

Vaš Ignjatije ${ }^{121}$

Jobu najbliži čovjek u Politici bio je očito karikaturist Pjer Križanić. Kao što je Boško imao što reći Vladanu glede jezika u suradnji s Politikom, imao je i Job glede ćiriličnog pisma njegove ponude!

Neovisno o tome što se sve u to doba dešavalo u vezi s Politikinim stalnim dopisničkim mjestom u Splitu, Vladan ga očito nije dobio. Ostao je na svome pripravničkom mjestu u Državnom pravobranilaštvu i, umjesto Politike, preostajala mu je tjeskobna šansa učiniti se kulturno i umjetnički prepoznatljivim koristeći projekt Magazina/Almanaha Sjeverne Dal-

\footnotetext{
20 Isto.

121 Ignjat Job - Vladanu Desnici, Beograd, 11. 10. 1933. (ćir.), OOVD, kut. Prepiska do 1945. I. Sprijeda na omotnici stoji „Gospodin / Vladan Desnica / advokat / Split / Sinjska ul. 7“. Straga nema Jobove adrese. Omotnica ima otisnut logo i ćirilično otisnuti naziv tvrtke s adresom („NARODNA ŠTAMPARIJA / Beograd / Poenkareova 24“).
} 
macije. ${ }^{122}$ Budući da je ova inicijativa vremenski koincidirala s njegovim pismom Matici od 7. listopada 1933., moguće je pretpostaviti da je vjerovao da će Matica nakon toga prekinuti suradnju. Bilo mu je stalo da to učini ona, a ne on, tj. da odgovornost za neupjeh projekta bude Matičina, a ne njegova jer je bio uvjeren da bi jedino to bilo pravedno poslije svega što se dogodilo. Najmanje se radilo o njegovoj sujeti. MSD je za Desnicu postao, nakon što se misaono identificirao s njime, projekt programatske važnosti.

\section{DESNIČINA PROGRAMSKA KONCEPCIJA MAGAZINA SJEVERNE DALMACIJE}

Kao što se od 1932. do 1935. godine postupno mijenjao odnos Vladana Desnice prema projektu MagazinalAlmanaha Sjeverne Dalmacije, tako se preoblikovala i programska koncepcija časopisa. O tome svjedoči već i činjenica da je u MSD iz 1934. godine na str. 2 otisnuta kratka urednička „Napomena“, a na str. 3 nenaslovljeni predgovor. „Napomena“ inzistira „da nije namjera ovog 'Magazina' da istakne i nametne neku svoju ideologiju i svoj program; on hoće samo da bude slobodan izraz težnja i ideja ovoga kraja i njegovih ljudi.“ Sva je u „Ich-Form“. Nenaslovljeni predgovor sav je u „Wir-Form“, npr.:

Naši su kulturni radnici rasijani po čitavoj državi i djeluju u raznim sredinama, pa se zaboravlja da su svi oni sinovi jednog kraja i nosioci jedne kulturne tradicije; njihov se rad, uzet kao cjelina, nema u vidu i nedovoljno se honorira. - U „Magazinu“ će oni imati prilike da nastupe zajedno, povezani pripadnošću istoj cjelini.

Pojam tradicijski oblikovane geokulturne cjeline „Sjeverne Dalmacije“ već je par excellence ideologijski, koliko god Desnica - nesumnjivo s najdubljim uvjerenjem - u „Napomeni“ naglašavao „najširu slobodu i punu odgovornost, kako u formalnom pogledu narječja, pravopisa i pisma, tako i u materijalnom pogledu idejnog sadržaja“. Na kraju nenaslovljenog predgovora nije s tim u vezi otvorio očekivani eksplicitno dijaloški pa i polemički prostor časopisa već je optimistički obećao da će vršenje „ovih zadataka“ zadovoljiti „duhovne potrebe jednoga kraja, a i za cjelinu će značiti nesumnjivu dobit“. ${ }^{123}$ Time se je modificirano vratio na Petranovićevo utilitarno pa i normativno shvaćanje funkcije časopisa.

Prema Odgovoru, Desnica je u kolovozu 1933. na zahtjev Matice povukao dva svoja teksta („Napomena“ i „Sintetični pregled“). ${ }^{124}$ Otvoreno je pitanje je li „Napomena“ objavljena u MSD 1934. identična povučenoj i što je bilo sa „Sintetičnim pregledom“. Stričevo pismo s početka 1934. godine svjedoči da je nenaslovljeni predgovor formuliran pred ulaganje rukopisa prvog sveska u tisak:

\footnotetext{
122 Kako nema vijesti o bilo kakvu očevu zauzimanju za to mjesto, moguće je pretpostaviti da je on bio protiv toga da njegov sin postane novinar, makar i kao stalni dopisnik Politike iz Splita. Vjerojatno je i dalje u njemu vidio svog nasljednika u odvjetničkom uredu.

123 MSD, 1/1934., 2-3.

124 Vidi bilj. 97. O „Sintetičnom pregledu“ nigdje više, prema sadašnjim uvidima, nije bilo riječi.
} 
Dragi Vladane! Predgovor je krasan: pametan, dubok, pun ideja i to tačnih i pametnih ideja, u formi lijep, uzdržan, bez manjilokvence, fraza i vulgarnosti. In una parola: perfetto i barba ti iskreno čestita i godi che il vecchio albero abbia messo (Nečitko - D.R.) germoglio. Neke male napomene napisao sam ti na karti. ${ }^{125}$

„Napomena“ i nenaslovljeni predgovor po svojim sadržajnim intonacijama nisu nastali istovremeno. Moguće je pretpostaviti da je nenaslovljeni predgovor, neovisno o stričevoj reakciji, nastajao duže vrijeme i da je u svome konačnom obliku reflektirao manje-više sve faze kroz koje je prošao projekt MSD od 1932. do 1934., a da je „Napomena“ nastala u nekoj specifičnoj situaciji, kada je Desnica što dosljednije morao braniti svoju uredničku autonomiju, ali i elementarna prava koja pretpostavlja građanski shvaćena sloboda stvaralaštva pojedinca. Ostaje otvoreno pitanje zašto u konačnici „Napomena“ i nenaslovljeni predgovor nisu objedinjeni u jedinstven tekst.

Temeljni prijepor u vezi s čovjekovim stvaralačkim mogućnostima u geokulturnim datostima, kao što je to konkretno „Sjeverna Dalmacija“, javlja se u MSD u više radova, u različitim varijacijama, prije svega u Desničinim, koje nas ovdje najviše zanimaju. U XI. odjeljku eseja „Jedan pogled na ličnost Dositejevu“ Desnica je usporedio Dositeja Obradovića i Petra II. Petrovića Njegoša:

Dositej je - više po nepresušnom izvoru svoje lične biti i svog individualnog prirođenog osjećaja, nego po uniformiranoj kolektivnoj ideologiji svoga vremena - naš najveći optimista.

Njegoš, intelektualno nesravnjivo jači, kršna gorostasna duhovna pojava, čovjek od energije, od volje, čista državnička, vlastodržačka priroda, bez predrasuda i iluzija o životu, gleda na život i svijet jednim skeptično-realnim i pesimistično-pozitivnim pogledom. Naš najveći pesimista, njegov je pesimizam čist od svake sentimentalnosti, od slabosti i remisivnosti. I u tom pesimizmu ima mnogo snage, i to životne, pozitivne snage. Njegošev je zahvat u život snažan i obiman i auktoritativno siguran. Njemu, stvarno, pesimizam znači jedan pozitivan životni princip, i sazdan je od trijeznog rasuđivanja, hladnog iskustva i nesentimentalne skepse, daleko od liričkog žala, od inertne remisivnosti i od sladunjave razočaranosti. - I, s tim, Njegoš je u punoj mjeri čovjek od akcije. ${ }^{126}$

Danas, poslije svega što je nakon 1934. godine kritički napisano i o prosvjetiteljstvu i o romantizmu te o romantičarskom prosvjetiteljstvu i o prosvjetiteljskom romantizmu ove binarno suprotstavljene Desničine misli ne djeluju kao što su s pravom djelovale kada su bile objavljene - snažno, misaono, prevratnički prema tradicijskim kanonima. Kritički esej o Dositeju Desnica je u konačnici pretvorio u svojevrsnu apologiju Njegoša kao inkarnaciju pesimizma kao pozitivnog životnog principa, a to je već uvelike bila jedna od najvećih tema 1930-ih godina. Još nešto. Razmišljajući o Dositeju, Desnica je isključio geokulturni horizont. Ograničio se - današnjim rječnikom - na historijskoantropološki. Njegoš mu je pak „kršna gorostasna duhovna pojava“, tj. njegov je pesimizam bio i geokulturno kondicioniran.

125 Boško Desnica - Vladanu Desnici, [Obrovac], [?] [?] [1934.], OOVD, kut. Prepiska do 1945. I.

126 Vladan Desnica, „Jedan pogled na ličnost Dositejevu“, MSD, 1/1934., 122. 


\section{ВААДАН ДЕСНИМА :}

\section{ЈЕДАН ПОГАЕД НА ЛИЧНОСТ ДОСИТЕЈЕВУ}

I.

Ни о којем другом нашем писцу није писано колико о Доситеју. Значајан као прекретница у нашем духовном животу, као навјештач једне нове ере; значајан по својој плодној и вишеструкој дјелатности и по опсежности подручја на којему је ту дјелатност вршич; иноватор, модеран, европљанин, - цоситеј је, стицајем прилика и по својим прирођеним склоностима, одиграо једну нагючито важну улогу и заузео једно одлично мјесто у историји наше књижевности.

И управо ради тога што је увијек проматран као носилац своје функције и као експонент своје епохе, мање се је пажње посветило Доситеју као човјеку, као индивидуалности: он је постао птерсонғ фикација једне идеологије и једног духа времена.

Но ипак свак, макар и несви јесно, осјећа да Доситејеву књижевном дјелу даје извјесну живост, пријемљивост и дјеловање непіто лично, нешто особено негово.

Управо то лично нас у овом часу занима и тиме хоћемо да се овдје позабавимо.

II.

0 Доситеју је, рекосмо, писано врло много: имамо исцрпне биографије, монографије и спецу јалне студује, у којима су опсежно захваћени и темељито проучени историјски и културни моменти Доситејева доба и њихов утицај на њ. У тим радњама су онажана оштра, дедукције правилне и судови тачни, а Доситејев жкивот и рад приказани су исцрпно. Али и послије свега тога као да је остало нешто необјашњено у Доситејевој појави, као да је занемарена права суштина негове личности и као да није истакнута његова најосновнија, најбитнија црта. Зато на концу увијек остаје отворено једно питање и неизглађена једна неподударност: у личности Доситејевој одмах на први мах осјетимо извјесну величину и извјесну врц једност, док напротив суд до којега дођемо ако га размотримо и као мислиоца и као књижевника и као просвјетног писца не оправдава ту непосредну импресију. Та непо-

\section{0}

Sl. 8. Vladan DesnicA, „Jedan pogled na ličnost Dositejevu“ između Glasa i Magazina Sjeverne Dalmacije, 1933. i 1934.: intelektualni elitizam u vremenu korporativističke političke kulture 
U eseju „Mirko Korolija i njegov kraj“ krenuo je drugim smjerom. Geokulturni i geopolitički horizonti dalmatinskog zaobalja preslojavaju jedan drugi u dugome povijesnom trajanju fiksirajući „morlačke“ kolektivnopsihološke limite:

(...)... sudbina ovog doseljenog življa od prvog časa kad je naselio ove krajeve bila je neobično teška. Napustivši svoja ognjišta i skloniv se pod okrilje mletačke republike, nastavio je bez predaha vjekovno krvljenje s Turcima, a u isto vrijeme postao je za Veneciju predmet svakojakog iskorišćavanja. Zemlja koju je naselio bila je većim dijelom siromašna, krševita i pusta. Tuđinske vladavine držale su smišljenim programom ovaj živalj u kulturnoj zaostalosti i svim sredstvima ugušivale svaki njegov napor za kulturnim pridizanjem. Kad je prestalo klanje s Turcima, počeli su vjerski progoni; dok je u Evropi nacionalna svijest slavila trijumfe, ona je ovdje davljena u povojima, a kad se je ta svijest uspkros svemu probudila i ojačala, počelo je sijanje plemenskog i vjerskog razdora.

Razumljivo je da je toliko stradanje spriječilo da se ona krepka i pozitivna narodna snaga nesmetano razvije i racionalno primijeni. I kobne posljedice zaostalosti i nerazvijenosti pokazuju se jasno još i danas na psihi tog naroda. Odatle, kao glavna negativna strana, ono jako izraženo nedostajanje duhovnosti i poriva za viši razmah. (... $)^{127}$

Kada je riječ o Njegošu u eseju o Dositeju, nema riječi o bilo kakvu geodeterminizmu. Prije bi se moglo reći obrnuto da je usporedljivi „gorštački“ kulturni krajolik u Crnoj Gori, konkretno u Njegoševu slučaju, imao jedne učinke, a u Sjevernoj Dalmaciji pa i čitavu dalmatinskom zaobalju druge. Na ovoj drugoj Desničinoj strani nema „Njegoša“. Nije nam cilj obesmišljavati Desničine radove objavljene u MSD. Naprotiv. Oni anticipiraju teme njegovih vrhunskih književnih ostvarenja od Zimskog ljetovanja do Proljeća Ivana Galeba. Ovdje je važnije što citirani ulomci iz eseja o Koroliji reflektiraju velik dio Desničina uredničkog historiografskog i kulturnohistorijskog programa. $M S D$ je u svoja dva objavljena sveska urednički, u granicama mogućnosti, minuciozno oblikovana cjelina.

Ovdje nas više zanimaju kreativni aspekti njegove programske koncepcije koji su slijedom citiranih misli de facto otvorili proces kritičke reevaluacije sjevernodalmatinske baštine s ciljem da je se istraživački dekodira i iz kontinentalnih i iz inzularnih i iz litoralnih perspektiva, ali u njihovim međuovisnostima i mnogostrukostima očitovanja tih međuovisnosti. Ratnih, vjerskih, društvenih i kulturnih, etničkih, sociopsiholoških i drugih povijesnih sadržaja ima toliko da bi $M S D$ - da je duže izlazio s takvom uređivačkom politikom - bio nezaobilazan kao inovacijski referentna historiografska publikacija. Važno je pritom uočiti velike tematske razlike u sadržaju historiografskih i kulturnosocijalnih sadržaja između prvog i drugog sveska. (Na stranu pitanje zašto je Desnica u drugom svesku odustao od inače uspješnog rubriciranja sadržaja, za što se postojano bio zalagao u pregovorima s Maticom. ${ }^{128}$ ) Dok u prvom svesku prevladavaju kontinetalnodalmatinski sadržaji, u drugom

127 Vladan DesnicA, „Mirko Korolija i njegov kraj“, MSD, 2/1935., 118.

128 Jedna od dilema uređivačke politike odnosila se na uvođenje rubrike prikaza. Boško Desnica je izričito bio protiv toga: „Ipak ja nebi savjetovao da se u Almanahu donose bilo kakvi prikazi. Ad quid? Sve su te knjige već prikazane i ocijenjene, pa bi ti prikazi izgledali i bili u stvari 'soffietti' con molto scapito po dostojanstvo publikacije. Mi sa Almanahom dajemo našu mjeru - a drugi nek nas ocjenjuju.“ (Boško Desnica - Vladanu Desnici, Obrovac, 31.7. 1933., OOVD, kut. Prepiska do 1945. I.) 
svesku većina je priloga posvećena litoralnim i inzularnim temama. Veliku težinu dobile su baštine Zadra i Šibenika u njihovom zlatnom dobu, kao i stvaralaštva pojedinaca u njima.

Dok je u prvom svesku bio vrlo uočljiv esej dr. Uroša Desnice „Jugoslovenstvo kao narodnost“, u drugom je svesku isto tako bio vrlo uočljiv esej Vladimira Rismonda „Za jednu dalmatinsku kulturnu orijentaciju“. ${ }^{129}$ Zadržat ćemo se na oba priloga jer su možda i najreprezentativniji za razumijevanje uredničke koncepcije i uređivačke politike Vladana Desnice.

Dr. Uroš Desnica je svojim esejom pledirao za jugoslavenstvo kao narodnost u vrijeme kada je ono na sve strane u Kraljevini Jugoslaviji bilo masovno osporavano u svojim konkretnohistorijskim realizacijama. Radio je to uvjeren da ono izražava povijesno otvoreni proces samoopredjeljenja Jugoslavena kao Južnih Slavena. Demonstrirajući dobro poznavanje suvremenih europskih rasprava o pojmu naroda i narodnosti, opredijelio se za koncept nacionalnih elita kao aktera stvaranja narodnosti logikom spoznate „istorijske nužnosti“. Pritom je dekonstruirao osnovne modele shvaćanja naroda i napose narodnosti kao „objektivnih“ i „subjektivnih“ povijesnih tvorbi te izveo vlastito shvaćanje ključnog pojma. Po njemu,

(s)ami za sebe, ni rasa, ni jezik, ni vjera, ni zajednica interesa, ni prirodne geografske granice, ni država, ni isti kulturni uticaj, ni zajednički istorijski udesi ne mogu da stvore narodnost, ali kod stvaranja narodnosti svi ovi faktori imaju svog uticaja, a gdje više tih faktora utiče i što oni jače utiču, to je proces formiranja narodnosti brži i prirodniji a produkt solidniji i savršeniji. ${ }^{130}$

Ipak, referirajući na Renana, ustvrdio je da „(č)ovjek nije rob ni rase, ni jezika, ni vjere ni toka rijeka ili pravca planinskih lanaca. Jedna velika skupina ljudi zdrava duha i topla srca stiče jednu moralnu svijest - $i$ ta je svijest narodnost". ${ }^{131}$

U jugoslavenskom slučaju, prema dr. Desnici, narodna književnost je u svome dugom povijesnom trajanju temeljni činilac konstituiranja zajedničke kulturne svijesti:

Pred dvadesetak godina pronađen je t. zv. Erlangenski rukopis, najstarija pismena zbirka naših narodnih pjesama, koja nam svojom smjesom dijalekata, krajeva, junaka, vremena i događaja daje najznačajniji dokaz o jedinstvenoj kulturnoj osnovi i o podudarnosti istorijskih udesa našega naroda. ${ }^{132}$

Dakle,

mi (Jugoslaveni - D.R.) imamo i kulturno-istorijsku tradiciju, koja nam daje zajednicu uspomena i težnja, koja nam je nametnula zajedničke napore i žrtve i koja je u nama stvorila ono što Renan zove „quelque chose de superieur à la langue: la volonté; la volonté d'être unis“ $\mathrm{i}$ „le consentement, le désir clairement exprimé de continuer la vie en commun“.133

129 Dr. Uroš DesnicA, „Jugoslovenstvo kao narodnost“, MSD, 1/1934., 127-135; Vladimir Rismondo, „Za jednu dalmatinsku kulturnu orijentaciju“, MSD, 2/1935., 111-116.

130 U. Desnica, "Jugoslovenstvo kao narodnost", 132.

131 Isto, 131.

132 Isto, 134.

133 Isto, 135. 
Njegov je zaključak bio nedvosmislen:

Kod ovolikog sticaja nacionalno djelujućih elemenata mi smo neosporno jedna formirana, potpuno dozrela i savršena narodnost sa svim atributima i svim značajkama ove, kao što je naziva Slobodan Jovanović, „istorijske nužnosti““134

Riječi su bile napisane u godini u kojoj je kralj Aleksandar I. Karađorđević, autoproklamirana inkarnacija jugoslavenstva kao „istorijske nužnosti“, bio ubijen. Dr. Uroša Desnicu to nije pokolebalo da do kraja svog života ostane uvjeren u njegov povijesni smisao. Na kraju, treba napomenuti da je autor porekao tvoračku moć vjere u stvaranju narodnosti (,(v)jera je najmanje podesna, bar u današnje doba, da bude činilac u stvaranju narodnosti“). ${ }^{135}$ „Vidovdansku etiku“ nijednom nije ni spomenuo.

Vladimir Rismondo je u eseju „Za jednu dalmatinsku kulturnu orijentaciju“ otvorio tada uistinu vrelo ,pitanje čuvanja njezine

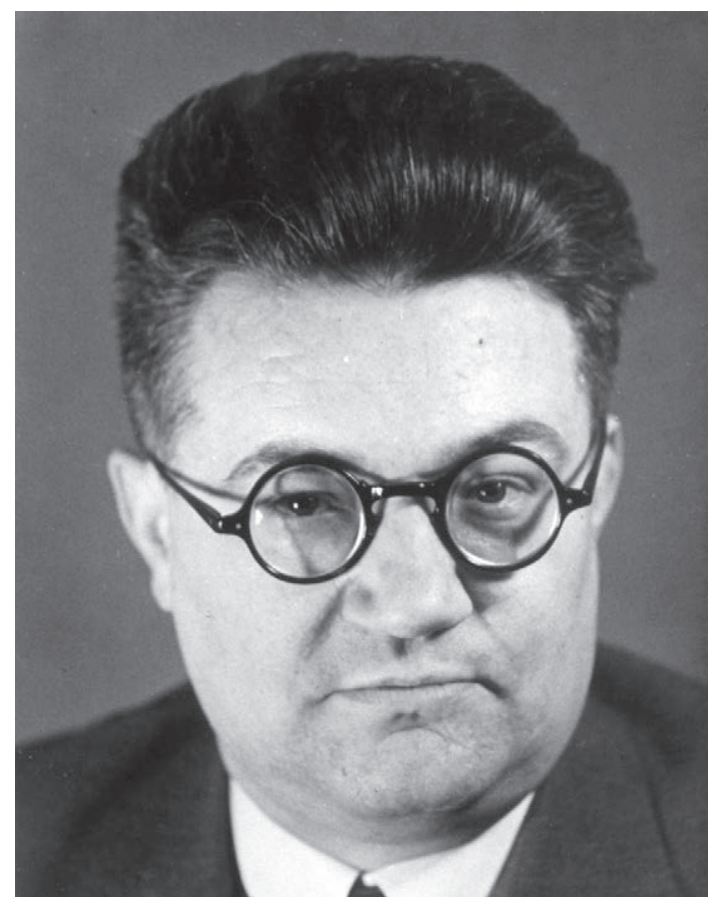

Sl. 9. Dr. Mate Ujević: kritički o dalmatinizmu/ mediteranizmu u Magazinu Sjeverne Dalmacije 1935. (dalmatinske - D.R.) specifične fizionomije u literarnom i kulturnom životu“, što je za njega značilo i neizbježno propitivanje zašto se prekida „intimna i neposredna veza s jednom svojom i kulturnom prošlošću“, ali i „intimna veza s terenom na kojemu je ta prošlost živjela i na kojemu (...) još uvijek živi““ ${ }^{136}$ Prema autoru, „nemoguće [je] uništiti jednu, u sebi organsku evoluciju od nekoliko vjekova“. Dodaje da bi i dalmatinski duh, „u traženju samoga sebe, neizbježno morao da opet posegne za svojim vjekovima“. ${ }^{137}$ Rismondo je mišljenja da su različite teorije progresa bile u korijenu ovog nerazumijevanja vlastite baštine te da „trpimo od uvjerenja da smo u poređenju s ostalim zemljama u svakom pogledu zaostali, da izgubljeno vrijeme moramo pošto-poto da nadoknadimo". 138 Britkim formulacijama svojih misli Rismondo je sustavno gradio svoju argumentacijsku matricu, koja je u to doba bila inkompatibilna s nacionalnim ideologijama u Dalmaciji, kako hrvatskima tako i srpskima, zaključivši da „po svemu izgleda da se nalazimo u apsurdnoj situaciji nekoga koji se dezinteresuje za ono što već odavno posjeduje, da se zatim uputi u traženje i polagano sticanje toga istoga (jer je prava kultura samo jedna), i to putovima koje skoro nikako ne pozna“" ${ }^{139}$

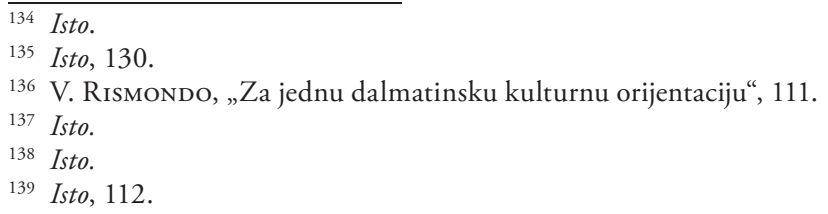




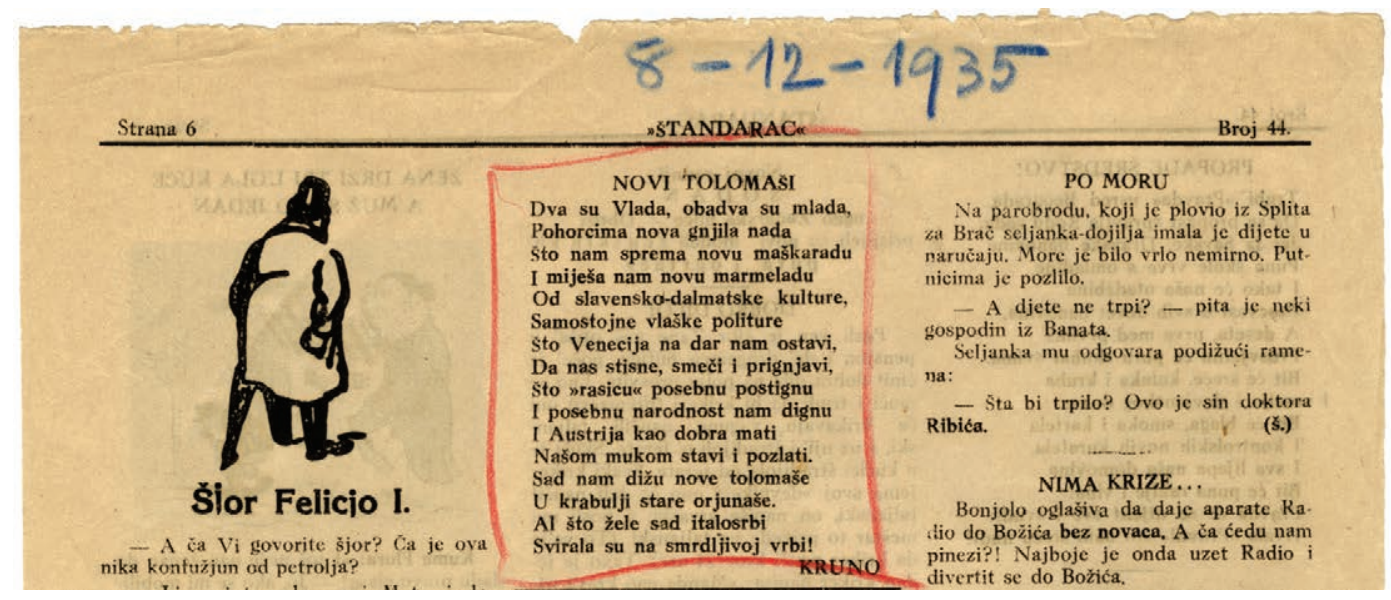

Sl. 10. Dva velikana suvremene hrvatske kulture u retrospektivi: „Dva su Vlada, obadva su mlada...“

On je konkretnohistorijski kontekstualizirao svoju tezu objašnjenjem da je „ova situacija samo nužna posljedica teških političkih lomljenja, u kojima su se, skupa s ostalim Balkanskim Slavenima i tražeći jednu zajedničku domovinu i državu, koju nisu onda još imali, lomili i Slaveni iz Dalmacije“. ${ }^{140}$ Nakon što je Jugoslavija stvorena „možemo da pristupimo razmatranju jednog našeg posebnog kulturnog problema i da se bavimo pitanjem čuvanja dalmatinske kulturne individualnosti, s tim više što se baš jedna takova Dalmacija, kulturna na jedan svoj i osebujan način, nalazi uzidana u samim temeljima duhovnog jugoslavenstva“" ${ }^{141}$ Njegova je ključna misao bila da se dalmatinski književnik i intelektualac treba „mnogo više nego što to danas radi posveti[ti] upoznavanju svoje domaće kulture, onamo od prvih latinskih i slovinskih kroničara i začinjavaca pa sve do Đorđića i Kačića, a isto tako i intenzivnom proživljavanju svih onih socijalnih i kulturnih činjenica koje su se, paralelno i simultano s njegovim domaćim, na otvorenom Mediteranu zbivale i uvijek na njih uticale“. ${ }^{142}$ Vjerojatno Rismondov esej i ne bi bio izazvao većih osporavanja da on izlaz iz postojećeg stanja nije kondicionirao i nepodavanjem „odveć važnosti savremenoj produkciji i teoretisanju naših centara u unutrašnjosti, koji, aritmetički i statistički nastrojeni, danas osnivaju svoju snagu više nego na drugom na povećem broju stanovništva i, uime toga, hoće da vode odlučujuću riječ u životu svih nevelegradskih dijelova zemlje“. ${ }^{143}$ Nasuprot tome, sinteza može biti samo europska, „a evropsko partikularno i na polju kulture nacionalno, zahvaćeno u jednoj široj sintezi zapadne civilizacije, znači isto što i naše regionalno, integrisano u jednoj manjoj, dinarsko-mediteranskoj sintezi na Balkanu“. ${ }^{144}$

Neovisno o povijesnoj „sudbini“ Jugoslavije i tada i kasnije, danas, u Europi regija, teško je razumjeti ostrašćenost s kojom su i Rismondo i Desnica bili napadani nakon objavljivanja ovog eseja. Manje je to teško kada se ima na umu da je proces nacionalizacija kultura u

\footnotetext{
140 Isto.

141 Isto, 113.

142 Isto, 114.

143 Isto, 115.

144 Isto, 116.
} 
Jugoistočnoj Europi najčešće bio shvaćen ne kao proces koji će europski legitimirati nacionalne kulture u procesima modernizacijskih transformacija kontinentna, nego prije svega kao proces koji će ekskluzivnom nacionalizacijom baština razoriti pretpostavke na kojima je nacija kao fenomen modernizacije uopće bila/jest moguća.

$M S D$ nam danas otkriva Vladana Desnicu kao pasioniranog poklonika historiografskih studija o Sjevernoj Dalmaciji i to prije svega onih utemeljenih na povijesnim vrelima. U prvom svesku rubrika „Istorija“ prethodila je rubrikama „Književnost“ i „Kulturna i socijalna pitanja“. U drugom svesku svega jedan članak - prilog Lucijana Marčića „Uzroci slabog ekonomsko-kulturnog razvoja zadarskog zaleđa“, koji je i sâm bio historiografski osmišljen - prethodi cijelom nizu historiografskih i kulturnohistoriografskih priloga. Spomenuti Rismondov članak „Za jednu dalmatinsku kulturnu orijentaciju“, također historiografski osmišljen, napravio je prijelaz prema prvom Desničinu radu „Mirko Korolija i njegov kraj“ te Korolijinima posthumno objavljenima „Zoe Porfirogeneta, dramski poem, I čin“ $i$ „Četiri posmrtna soneta: Novo proleće - Osmeh - Ljubavni psalam - Istočnik“ $i$ drugom Desničinu radu „Životna staza Jandrije Kutlače, skica za roman“. Desničin esej o Koroliji možemo razumjeti i kao pledoaje za drugačije, vlastito poimanje sjevernodalmatinskog književnika i njegova kraja. Životnu stazu Jandrije Kutlače - koji „ulaznicu“ u žuđeni svijet izvan dinarske zabiti plaća, pored ostalog, prelaskom s pravoslavlja na rimokatoličanstvo, dakle, reagirajući drugačije nego Matavuljev Pilipenda - također možemo shvatiti i kao drugačiji, transkonfesionalni pristup vječnim ljudskim pitanjima. ${ }^{145}$ Zaključujući drugi svezak književnim blokom, a prestajući objavljivati $M S D$, kao da je simbolički izabrao svoj daljnji književnički put.

\section{ZAKLJUČAK}

Vraćajući se na početno postavljena pitanja u ovom članku te na radnu hipotezu o Desničinu $M S D$ kao o interkulturnom i dijaloškom glasilu u dalmatinskoj subregiji, subregiji ne(s)poznate prošlosti i neizvjesne budućnosti i to u kriznom trenutku njezine povijesti, mislimo da je moguće zaključiti da je mladi Desnica po svojim temeljnim vokacijama bio ne samo umjetnik nego i intelektualac otvoren prema društvenoj zbilji svog vremena. Umjetničke istine nisu isključivale društveno- i kulturnopovijesne. Naprotiv, jedne i druge su dijelile odgovornost za humanizaciju konkretnih društvenih zajednica, kao što je u ovom slučaju to bila Sjeverna Dalmacija. Koliko god Vladan Desnica u godinama MSD bio svjestan društveno i kulturno kondicioniranih zaostalosti i rascjepa u Sjevernoj Dalmaciji, oni za njega, kao ni za suradnike koje je bio okupio, nisu bili usud, nego povod da se kontrastirajući iskustva prošlog i mogućnosti budućeg otvori raspravu o (sub)regionalno

45 „Pilipenda“ je naslov pripovijetke Sime Matavulja o istoimenom seljaku koji je u godinama gladi u Dalmaciji u prvoj polovici 19. stoljeća više volio ostati gladan nego prijeći s pravoslavlja na katoličanstvo, što je bio uvjet kojim su državne vlasti uvjetovale ispomoć u prehrani pravoslavnih. Vidjeti Simo Matavulu, Pilipenda i druge pripovijetke, Sarajevo 1970 . 
održivim alternativama. Na kraju, podržavajući istraživanja konfliktnih razvojnih dinamika u Sjevernoj Dalmaciji u dugom povijesnom trajanju, bio je uvjeren da etnički („rasni“) i kulturni princip nisu inkompatibilni nego naprotiv - da jedino interkulturnim logikama, $s$ jedne strane, političke, jugoslavenske sinteze i, s druge strane, dalmatinske odnosno mediteranske kulturne sinteze (Sjeverna) Dalmacija može osigurati bolju budućnost. U tom smislu Desničinu Magazinu Sjeverne Dalmacije danas ne treba ni povijesna rehabilitacija ni povijesna osuda. Treba ga razumjeti u vremenu u kojemu je nastao i nestao te kao moguću pouku za budućnost u onome održivom i u onome neodrživom u njegovoj baštini. Kao fenomen, nesumnjivo je reprezentativan za svoje doba. Kao jedan od ključeva za pristup zrelom Desnici sigurno je nezaobilazan. Serije nesporazuma, sporova i sukoba koji su pratili projekt Magazina Sjeverne Dalmacije imale su učinak spoznajnog katalizatora i prijelomno su utjecale na Vladana Desnicu da svoje stvaralaštvo posveti umjetničkim, književnim istinama kao jedinom putu prema „goloj istini“ (V. Desnica) o čovjeku. Nikada kasnije nije govorio o svom iskustvu Magazina Sjeverne Dalmacije, kao što nikada kasnije nije bio urednik pa čak ni član uredništva nekog časopisa.

\section{Vladan Desnica and the Journal Magazin SJeVERne Dalmacije: the Author and the Power(lessness) OF TRADITION}

In his later years, Vladan Desnica never publicly spoke about the journal Magazin Sjeverne Dalmacije. This paper attempts to historiographically answer, through an analysis of some newly utilized sources, the following questions: What were the existential and professional, as well as artistic orientations of Vladan Desnica in the years after his legal studies completed in Zagreb in 1930, more precisely, after his return to Split? Was the MSD his temporary or long-term interest? Why did he need the cooperation of the Economic and Cultural Matrix for Northern Dalmatia and its journal Glas? What did the Matrix and the Glas mean in Dalmatia of the time, and what did the Matrix's key figures expect of Desnica? What had been changing in the Matrix and the Glas since the inauguration of Dr. Irinej Đorđević as Orthodox bishop of Dalmatia in 1931? Did Desnica adapt his original concept of the journal in his editorial practice from 1932 to 1935 following changes taking place in Northern Dalmatia? What were the contributions of Vladan Desnica in the MSD as an author? What were the contributions of his father Dr. Uroš Desnica and uncle Boško Desnica? Why did the "Statement from Northern Dalmatia" appear? What was the Response to the "Statement"? How does one explain the many conflicts regarding the MSD? Can one reconstruct their chronologies? How much and in which way was Vladan Desnica involved in them? Finally, what did the MSD mean for Vladan Desnica?

Today the MSD reveals Vladan Desnica as a passionate devotee of historiographical studies of Northern Dalmatia, first and foremost those based on primary historical sources. In the first volume, the section on history preceded the sections on literature and cultural and social matters. In the second volume, just one article which was devoted to social and cultural backwardness of the Northern Dalmatia, preceded a range of historiographical and cultural history articles. Howe- 
ver, the article by Vladimir Rismondo "Za jednu dalmatinsku kulturnu orijentaciju”, also historiographically defined, formed the shift towards the final literary section, which also included his essay on Mirko Korolija and his novel "Životna staza Jandrije Kutlače”. His essay on Mirko Korolija could have been read at the time, as well as now, as Desnica's plaidoyer for a different, eminently personalized interpretation of the Northern Dalmatian author and his ending. The life of Jandrija Kutlača - a poor man who seeks an exit from the world of the Dinaric outback by crossing over from the Orthodox to the Catholic faith - we might also see as a different, postconfessional approach to the eternal questions posed by life. Concluding the second volume with a literary section, Desnica stopped publishing the $M S D$, and irrevocably traced his creative path and gave himself wholeheartedly to his literary vocation. Maybe he spoke of the experience with the MSD when years later he said the following: "And the irreplaceable value of literature, which defines its function and place in the spiritual sphere, lies in that which helps man reveal truths of such order that not even history, sociology, psychology, or any other spiritual activity can reveal."146

Keywords: Vladan Desnica, Magazin Sjeverne Dalmacije, 1932 - 1935, Split, social and cultural development, historiography, literature, interculturalism

\section{$\cos$}

\section{Izvori i literatura}

\section{Neobjavljeni izvori}

Osobna ostavština Vladana Desnice (OOVD)

\section{Objavljeni izvori i literatura}

Sofija Božıć, Srbi u Hrvatskoj 1918-1929., Beograd 2008. (ćir.).

Boško DesnicA, „Jedna nepoznata buna i jedan neznani mučenik“, Magazin Sjeverne Dalmacije, 2/1935., 47-57 (ćir.).

Vladan DesnicA, „Doprinijeti vječitom cilju: očovječenju čovjeka“, Hotimično iskustvo: diskurzivna proza Vladana Desnice. Knjiga druga (prir. Dušan Marinković), Zagreb 2006., 94-96.

Vladan Desnica, „Izložba vajara Dujma Penića u Splitu“, Život i rad (Beograd), god. VI, knj. 17, sv. 99, Beograd 1933., 1211-1213 (ćir.).

Vladan Desnica, „Jedan pogled na ličnost Dositejevu“, Glas Privredno-kulturne Matice za Sjevernu Dalmaciju (Šibenik), br. 155, 1. 7. 1933., 2-3; br. 156, 13. 7. 1933., 2-3; br. 157, 28. 7. 1933., 2-3; br. 158, 16. 8. 1933., 2-3; br. 159, 31. 8. 1933., 2-3; br. 161, 14. 9. 1933., 2-3; br. 162, 22. 9. 1933., 2-4 (ćir. i lat.).

Vladan DesnicA, „Jedan pogled na ličnost Dositejevu“, Magazin Sjeverne Dalmacije, 1/1934., 110_ 124.

Vladan Desnica, „Kipar Dujam Penić. (Prigodom izložbe u Splitu)“, Novo doba (Split), br. 241, 14. 10. 1933., 9.

Vladan Desnica, „Mirko Korolija i njegov kraj“, Magazin Sjeverne Dalmacije, 2/1935., 117-129.

Vladan Desnica, „Prvu novelu namenio sam 'Politici'“, Hotimično iskustvo: diskurzivna proza Vladana Desnice. Knjiga druga (prir. Dušan Marinković), Zagreb 2006., 105-106.

$\overline{146}$ Vladan Desnica, „Doprinijeti vječitom cilju: očovječenju čovjeka“, Hotimično iskustvo. Knjiga druga, 95. 
Dr. Uroš Desnica, „Jugoslovenstvo kao narodnost“, Magazin Sjeverne Dalmacije, 1/1934., 127135.

Irinej ĐorĐević, Odabrani radovi (prir. Dragan Subotić i Borislav Čeliković), Gornji Milanovac 2003. (ćir.).

Glas Privredno-kulturne Matice za Sjevernu Dalmaciju (Šibenik), 1929. - 1936.

Aleksandar JAKIR, Dalmatien zwischen den Weltkriegen, München 1999.

„Jedna izjava iz Sjeverne Dalmacije“, Novo doba (Split), br. 217, 16. 9. 1934., 11-12 [!].

Stanko Korać, „Književna saradnja Vladana Desnice u 'Magazinu sjeverne Dalmacije', Književna reč (Beograd), 14/1985., br. 263, 16-18 (ćir.).

Gordana Krivokapić Jović, Oklop bez viteza. Organizacione osnove i socijalna struktura NRS-a u Kraljevini SHS 1918-1929, Beograd 2001. (ćir.).

Ian MacPherson, Hands Around the Globe: A History of the International Credit Union Movement and the Role and Development of World Council of Credit Unions, Inc., Victoria (Canada) 1999.

Magazin Sjeverne Dalmacije, 1/1934.

Magazin Sjeverne Dalmacije, 2/1935.

Dušan Marinković, „Biografija Vladana Desnice“, Hotimično iskustvo: diskurzivna proza Vladana Desnice. Knjiga druga (prir. Dušan Marinković), Zagreb 2006., 227-229.

Simo Matavulu, Pilipenda i druge pripovijetke, Sarajevo 1970.

Jevto M. Milović, „Razgovor s Vladanom Desnicom o umjetničkom stvaranju“, Hotimično iskustvo: diskurzivna proza Vladana Desnice. Knjiga druga (prir. Dušan Marinković), Zagreb 2006., 114-139.

J. Carroll Moody - Gilbert C. FITE, The Credit Union Movement: Origins and Development 18501980, Dubuque (Iowa) 1984.

Odgovor na „Jednu izjavu iz Sjeverne Dalmacije“, Beograd 1934.

Ivo Perić, „Politička i kulturna djelatnost Božidara Petranovića“, Radovi Zavoda za hrvatsku povijest, 16/1983., 45-96.

Vladimir Rismondo, „Za jednu dalmatinsku kulturnu orijentaciju“, Magazin Sjeverne Dalmacije, 2/1935., 111-116.

Drago Roksandić, „Ratni dani Vladana Desnice“, Intelektualci i rat 1939. - 1947. Zbornik radova s mecunarodnog skupa Desničini susreti 2012. (ur. Drago Roksandić i Ivana Cvijović Javorina), sv. 2, Zagreb 2013., 528-555.

Severna Dalmacija nekad i sad. Odlučna reč u kritičnom času, Beograd 1939.

Čedomir VIŠNuIĆ, Srbi u Hrvatskoj 1918-1941: anotirana bibliografija, Zagreb 2000. 


\title{
Prilozi
}

\author{
Prilog I.
}

\section{Vladan Desnica - Privredno-Kulturnoj matici Za Sjevernu Dalmaciju u Šibeniku, SPLIT, 7. IO. I933. ${ }^{\text {I47 }}$}

Privredno kulturnoj matici

Š i b e n i k

$\mathrm{Na}$ Vaše pismo od 23/9 čast mi je ovim dati odgovor.

Najprije ću se osvrnuti na pojedine detalje uvjetâ koje je Matica postavila za primanje moga Almanaha u svoju nakladu, a zatim ću se pozabaviti nekim principijelnim pitanjima.

Odobravam popunu sadržaja svim predloženim člancima osim onoga o kontu Iliji Dedi Jankoviću. (Uzgred ću primijetiti taj detalj, da je pogrešno upotrebljen plem[ićki] naslov „graf“, jer je ta vrst plemstva germanskog porijekla i nema ništa zajedničko sa mletačkim plem[ićkim] naslovom „conte“, koji je mlet[ačka] republika ustanovila za svoje pripadnike koji nisu venecijanski gradjani; najbolje je zato plem[ićki] naslov ostaviti onakav kakav originalno glasi, samo transcribovan našim pravopisom = konte). Evo zašto sam mišljenja da se taj članak ne donese: o kontu Iliji je dosta pisano: pisao je opširno Simo Matavulj u svojim „Bilješkama jednog pisca“; Marko Car dosta neozbiljno i nekritično u svom predgovoru istom djelu; edicija „Znameniti Srbi“ donijela je uz kontovu sliku njegovu biografiju u glavnim potezima; Milićević je o njemu pisao, a ima još dosta članaka o njemu od manje važnosti. Po principu koji sam usvojio pri uredjivanju Almanaha i koji mislim da ima svog obrazloženja, članci koje budemo donosili u našim Almanasima treba da budu po nečemu novi, da donose nove podatke ili nove oglede, a ne da budu samo prepričavanje i ekscerpiranje onoga što je već davno pisano. Radi tog razloga u ovogodišnjem Almanahu nema govora o episkopu Končareviću, o Simi Matavulju i t.d.; nisam htio da donesem ma što, to toliko da bude o njima spomena, ali sam zato osigurao za dogodine dobru i iscrpnu radnju o Končareviću u kojoj će se iznijeti sustavno i iscrpno sve što se o njemu znade, sa dosta novih hist[orijskih] podataka i dokumenata, sa prikazom čitavog njegovog procesa u Mlecima (dokumenti nedavno otkriveni i još neobjavljeni), te novu radnju o Matavulju u kojoj će se okušati da ga se obradi bolje i potpunije nego što je to dosada bilo radjeno. Dosljedno tom principu, mišljenja sam da je bolje o kontu Iliji ne donositi ništa dok ne bude moguće kazati nešto konkretnije i novije o njegovom nacionalnom i političkom značenju i djelovanju, o njegovim književnim kvalitetama, i popratiti to iscrpnijim biografskim i drugim podacima. Ja sam bio ponudio piscu da ću mu staviti na raspolaganje članke i rukopise kontove, njegovu prepisku, i saopćiti mu biografske i druge podatke, pa sam to spravan da učinim i dogodine kad bude više mogućnosti za bolju i iscrpniju obradu tog predmeta.

Osim tog jednog članka, ponavljam, s drugima se dopunama slažem. 
S izostavljanjima, osim Vlačićevih dokumenata o Uniji i Ode Napoleonu, takođe se slažem, kad već Matica nalazi za shodno da tako učini. Ali, moram usput spomenuti, ja sam Govor Dra Desnice u Senatu i njegov članak o pravoslavnoj bogomolji u Splitu bio spremio medju priloge koji će tek eventualno ući u tekst Almanaha, a uvrstio sam ih tek onda i jedino zato kad mi je i zato što mi je g. Pretsjednik Matice rekao da ta dva priloga svakako moraju ući u Almanah, jer da su to živi i jasni dokumenti našeg života u ovim krajevima i naše borbe. Takovo gledanje na ta dva priloga opravdava ih i od prigovora da su postali neaktualni: donosi ih se kao dokument a ne kao članke koji tretiraju otvorena pitanja. A tim istim kriterijem rukovodila su se i gg. ocjenjivači Almanaha pri ocjeni i prihvaćanju ponekih priloga, tako na pr. članka o popovskoj birovini, koji je s novim Ustavom pravosl[avne] crkve postao neaktuelan, ali je ipak vrlo zanimiv kao dokumenat doba i prilika koji su minuli. No, kažem, to sam sve uzgred istaknuo, ali se s odlukom Matice potpuno slažem.

Nije tako s Vlačićevim dokumentima o Uniji. Ma da su Kirilo Cvjetković i episkop Milaš o tome pisali, pitanje s tim nije iscrpljeno. I o Cezaru i o Francuskoj revoluciji je mnogo pisano, ali se ipak još uvijek piše, iznose novi podaci, donose novi pogledi itd. A Vlačićevi prilozi svakako nam pružaju nove, zanimljive i autentične dokumente o tom pitanju. Uglavnom se ograničuju na citiranje izvornih akata Ministarstva policije i Pokr[ajinskog] Namjesništva, koji su nadjeni u austr[ijskim] arhivama. Ako njihova obimnost čini zapreku, onda je bolje - i ja to predlažem - da se izostavi prilog g. Boška Desnice „Jedna nepoznata buna ...", jer je štampan već tri puta i jer bi sâm auktor mnogo volio da se ne preštampava i po četvrti put, pa je tek na veliko moje navaljivanje nekako pristao. Kad bi se dakle taj prilog, na vruću želju auktora, izostavio, učinilo bi se mjesta Vlačićevim dokumentima koji to, po mišljenju mome i nekih stručnjaka, u punoj mjeri zaslužuju.

Što se tiče Ode Napoleonu, ona je dosta zanimiv prilog i sa gledišta knjiž[evne] istorije i sa gledišta polit[ičke] istorije. I u drugim zemljama koje su došle pod Napoleona pisane su takove ode, $\mathrm{u}$ jednakom nakindjurenom ruhu, kako je bila moda onog vremena, pa im je dato mjesto u istoriji knjiž[evnosti]. Tim više ona zaslužuje neku pažnju kod nas, što pretstavlja veću rijetkost, a značajna je i za poznavanje nastrojenjâ i raspoloženjâ u ono vrijeme. Osim toga, ona je naša u najužem smislu te riječi, i potpuno je nepoznata. Štampana je na koncu jednog „Malog Katihizisa“ prevedenog s ruskog „na naš prosti serpski maternji jezik“ i donekle preradjenog od jeromonaha Spiridona Miloradovića „ekonoma, pričetnika i paroha drniškog“. Knjižica je izdana 1811 u Mlecima, posvećena je predgovorom episkopu Venediktu Kraljeviću, i on je popratio „pastirskim preduvjedomlenijem k čitatelju“, štampanim u tekstu. Oda nadodana na kraju knjige nesumnjivo potječe, dakle, od Spiridona Miloradovića paroha drniškog, pa mislim da bi je svakako trebalo donijeti, naravno, popraćenu zgodnijim uvodom, što bih, do potrebe, mogao ja da pokušam. Osim toga trebalo bi je, naravno, štampati gdje joj je mjesto, a ne na pr. medju člancima ili istoričkim radnjama. Ali o tome ću u odjeljku o rasporedu materijala.

Dakle i s izostavljanjima se slažem osim u pogledu Vlačićevih dokumenata i Miloradovićeve Ode.

Pitanje rasporeda sadržaja. Držim da se pri ocjenjivanju nije obratilo dovoljno pažnje na neke momente koje sam ja pri uredjivanju imao u vidu, pa da se je tim nešto izgubilo.

Jasno je što može da dodje pod rubriku „KNJIŽEVNOST“ pa tu nema prigovora. Pod rubriku „NAŠI PROBLEMI“ mogu da se svrstaju napisi najrazličitijeg sadržaja, pa i to može da se prihvati. Nije tako s rubrikom „HISTORIJA“. Ta riječ je stručni izraz koji označuje jednu nauku. Prema tome, u tu rubriku idu samo napisi o važnijim, općenitijim dogadjajima, i ličnostima, pokretima. Nije „historija“ sve ono što je prošlost. Iz članaka Miloša Parente, Boška Desnice, Ljubomira Vla- 
čića čitalac bi dobio dojam da je tu u naslovu riječ „Historija“ upotrebljena zbilja u stručnom smislu, kao nauka, istoriografija, pa bi se začudio kad bi vidio u istom odjeljku napise koje ne spadaju u istoriju u tom smislu. Nekrološčići o Josi Mihaljeviću, Danici Baljak, Jelisaveti Simić, uspomene na Artura Evansa itd, ma koliko pretstavljali našu i nama dragu prošlost, nisu „istorija“ u gornjem smislu, pa takovi člančići ne mogu da stoje uz historiografske radnje i monografije. Isto vrijedi i za članke o prof. Grupkoviću, nisu „historija“ ni zapisi iz naše nedavne polit[ičke] prošlosti, ni članak o našim privrednim i kult[urnim] društvima do oslobodjenja, a najmanje člančić o Sundečićevu boravku u Žegaru. O tome mislim da će se saglasiti svi. Trebalo bi dakle to podijeliti u dvije rubrike: ISTORIJA, i tu bi došli članci o krupnijim istorijskim ličnostima, koje su čak postale junaci narodne epike, o seobama, bunama, dakle o dogadjajima, pokretima i ličnostima koje pripadaju istoriji; druga rubrika može da nosi naslov „IZ NEDAVNE PROŠLOSTI“ ili, još bolje, „NAŠI LJUDI I USTANOVE“, ili kako se već nadje za zgodno.

Držim da je naročito nezgodno to što se je ukinulo u odjeljku „KNJIŽEVNOST“ pododjeljak „Listak“ ili „FELJTON“ ili kako bi se već nazvalo. U taj bi pododjeljak spadali kao naručeni prilozi: „Boravak Sundečića u Žegaru“, „Jedna oda Napoleonu“, i slične lit[erarno]-istorijske vijesti i crtice. Jednako tako je nezgodno što se je ukinuo naslov „Naši pokojnici“. Tri nekrološčića koji kao takovi mogu da budu dobre stvarčice i kojima se odaje počast zaslužnim i skromnim našim radnicima na zajedničkim ciljevima, gube se u drugom kakvom odjeljku. Najmanje pak spadaju u „ISTORIJU“, o bok Mandušiću, uz „Pregled kult[urnog] razvitka Srba na primorju“. Da su ti pokojnici živi, njima bi samima bilo nelagodno od takove blizine.

U pogledu „Uvodnog dijela“ moram naročito istaknuti, da sam Korolijin sonet „Janković Stojan“ izabrao upravo i jedino zato što sam nalazio da odgovara kao stvoren za ono mjesto: na čelu knjige. A to stoga što nosi jednu široku ideju i što je pun smisla: Mlečić i Turčin, emblemi sv. Marka, paše, providuri - sve je to etiketa, sve je to nalijepljeno, sve je to neživo; jedino živo istinsko - to je vrela i živa narodna snaga, ona žilava rasa koja lazi k moru primitivna i neiscrpljena, koja daje i etnički i nacionalni i psihološki karakter ovoj zemlji, i koja, na koncu, ima jedina prava na upravljanje udesâ ove zemlje. Eto, tu ideju diskretno i jezgrovito izraženu u 14 stihova jednog soneta ja sam htio da postavim na čelo ovoj knjizi. Jedino tu ona ima smisla; kao literarni prilog ona gubi svako značenje i svaki smisao: to je jedna od najstarijih Korolijinih pjesama, štampana u zasebnoj knjizi pred ravnih dvadeset godina, pa ne bi imalo smisla da se sada iskopava i donosi - kao književni novitet. Dakle ako se hoće da skine s načelja knjige, nikako ne smije da udje u tekst, tim manje što mi je sâm auktor dozvolio preštampavanje samo za načelje knjige, a nikako kao liter[arni] prilog.

Književni prilog od Novaka Novakovića sam dobio, ali ga nisam mogao da uvrstim u tekst jer je bio slab. Dok u Jurkovićevoj noveli ima baš nešto što vrijedi: obradjuju se interesantni momenti kad su mentalitet i politička ideologija našeg kraja proživljavali jedan prelom, dotiče se pitanja hajdučije, crta prilike i psihološka nastrojenja poslije sloma Austrije i za talijanske okupacije - dotle je poslana novela Novakovićeva (Ićanova duša) mnogo slabija, pa sam držao da nikako ne može da udje u Almanah. Psihologija je naivna i nimalo vjerna, ličnosti risane konvencionalno, i čitava stvar nije imala u svojoj biti ništa našega. Kad bi poslao kakvu drugu bolju stvar, mogla bi se primiti.

$S$ tim bi detaljni pretres bio iscrpljen. Molim da Matica uzme u razmatranje ove primjetbe i razloge, pa da o njima donese svoju odluku.

Još moram da se osvrnem na neka principijelna pitanja koja su od kapitalne važnosti.

Ja sam stvorio zamisao Almanaha, ja sam napravio program rasporeda i prema njemu nastojao da priberem priloge, ja sam bio urednik Almanaha, pa sam ja prosudjivao, prihvaćao ili odbijao 
priloge. Prema svemu tome, ja sam vršio sve pokretačke i redaktorske funkcije, i tu je, osim mog materijalnog rada, dolazila do upotrebe i moja uvidjavnost, kriterij, kakva-takva sprema itd. Kao takav ja sam pregovarao s Maticom, i kao s takvim je Matica pregovarala sa mnom. Kad najednom - stvar se potpuno izmijenila. Ja sam postao nešto sasvim drugo: Matičina zamisao, Matičina redakcija, Matičina naklada, a ja sam samo prikupljao priloge. Rečeno bez uvijanja, ja sam postao nešto poput inkasatora, poput onih lica koja obilaze članove kakvog društva da pribiru članarinu. Samo što sam ja mjesto gotovine pribirao pismene sastave. Takovo Matičino naziranje najbjelodanije se vidi iz ovoga:

Almanah bi imao da nosi i moje ime, kao urednika, i Matičino, kao izdavača. Jasno je dakle da i ja i Matica nosimo svaki svoj dio moralne odgovornosti, i da se ni jedno od dvoga ne smije da povrijedi. Dosljedno tome, svi prilozi koje sam ja sakupio došli su pred Matičin forum da prosudi je li dostojno da Matica dade tome svoje ime, i to je sasvim naravno. Matica naprotiv nije mislila da treba da ima iste obzire prema meni: Matica, ni u teoriji, dakle, ne drži da i ja, bar formalno, moram da pregledam priloge koje ona sakupi pa da prosudim da li mogu da izidju pod mojom odgovornošću. Spravan sam da vjerujem da će svi ti prilozi biti od reda vrlo dobri, da neće sadržavati ništa što bi se bitno kosilo sa mojim načelima itd. itd., ali ipak sve to ne opravdava gornji postupak. Iz toga se vidi da se moji pogledi na moj položaj i na moju funkciju ne poklapaju sa Matičinim pogledom na taj položaj i funkciju, što, naravno, može da čini ozbiljnu zapreku za negocijaciju medju nama. Radi toga mislim da je bolje što sam ovo pitanje dotakao i pokušao da ga izvedem na čistac; zaista će svak priznati da bi bilo smiješno da se čitava ova negocijacija svrši i da knjiga izidje, a da ja još uvijek ne budem načistu u kakvom sam ja zapravo odnosu prema toj knjizi, odnosno da i onda još bude različitih poimanja tog odnosa.

Zato molim Maticu da i ovo pitanje uzme u razmatranje pa da i o njemu donese svoju odluku, odnosno iznese svoje stanovnište.

S odličnim poštovanjem

Vladan Desnica

Split, 7 oktobra 1933.

(4 lista, 6 strana, strojopis, latinica /Desničin potpis - ćirilica/) 


\section{Prilog II.}

\section{BošKo Desnica - Vladanu Desnici, Obrovac, I4. IO. I934. ${ }^{\mathrm{I} 48}$}

Dragi moj Vladane! Svako me tvoje pismo obraduje jer je meni uživanje i zadovoljstvo biti s tobom u umnom dodiru, uživanje mi je čitati tvoje smišljene, pravilne sudove o ljudima i stvarima, pratiti tok tvoje tačne i duboke misli, ali me svako tvoje pismo ujedno pomalo i rastuži jer vidim da ti tražiš i očekuješ od mene nešto što ja više nisam u stanju da dadem, vidim da ti suponiraš u meni jednu intrisečnu vrijednost, koju sam možda ja nekad i imao, ali koja se sada svela a bon poca cosa, na nešto što bi te zaprepastilo kad bi vidio koliko je sitno i neznatno. Ja sam, moj Vladane, jedan zahrgjao i izmoren um. Neznam jeli me satrla petnaestogodišnja dnevna borba „intra et extra“, barovitost i niskost sredine, briga za nasušnost, udaljenost od svijeta - ali znam pouzdano da nemam ni snage, ni inventivnosti, ni stručnosti, ni ustrajnosti za ikakvu stvar od većega daha i šireg zamaha. Sposoban sam za pabirčenje, za sitnice, za površnu analizu, ali za ono za šta me ti smatraš sposobnim, za ono ja više nisam. I najžalije mi je što sam, nenamjerno, obmanuo tebe i što sam ti spremio jedno neminovno razočaranje. Sve ovo što ti kažem nije plod jednog časovitog raspoloženja a još manje jedna provokacija komplimenata ili utjehe (što bi bilo slabićski i djetinjasto) već rezultat jedne nepogrešive introspekcije. I time se, vidiš, tumači i postaje razumljivo moje silno interesovanje za tvoj rad, za tvoj razvoj i za tvoj uspjeh. U tom ima i malo egoizma. Naime nada da ćeš ti ostvariti i svršiti ono što sam ja, prvi u našem rodu, zamislio i započeo.

Zato ja uživam kad iz tvojih pisama, razgovora, i radnja primjetim pojedine u tebi solidne osobine, koje pružaju jamstvo da će se moja nada ostvariti. Dakle ne računaj da ću ti moći dati radnju o Milašu, a nisam siguran ni za ono drugo što sam ti stavio u izgled. Mogao bi ti dati jednu seriju sitnijih priloga, poput onih lanjskih, ali manje važnih i manje zanimljivih, jer sam za lanjski iscrpio najbolje. Pokušaću preko Benje i Dra Viole dobiti Končarevićev proces, samo treba da mi tačno javiš za kad misliš izaći.

(...)

Pisaću sigurno ovo dana svima za koje si me molio. Sumnjam da će Karaman pristati, jer je on ekonomski ruiniran od žene, pa piše samo za honorar. Zato više i ne saragjuje u Novom Dobu.

Potpuno sam suglasan s tobom u pitanju polemike sa Glasom. Treba reagirati kad te lično očepe, a nikako vaditi kestenje za druge i zalagati se per reputazioni avareate, koje će ti na prvom kantunu okrenuti legja i izručiti protivniku čim se njih kane.

(...)

Zbogom moj mili, poljubi mi snašu.

Voli Vas mnogo

Barba

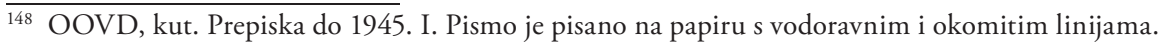




\section{Prilog III.}

\section{BošKo Desnica - Vladanu Desnici, KARIN, I6. 7. $1935 .{ }^{149}$}

Karin, 16. VII. 35

Dragi moj Vladane,

sinoć sam primio tvoje pismo a već preksinoć bio sam dobio Magazin od ćaće, koji je u negjelju popodne bio ovgje sa majkom i kumom. Bili su na večeri i ostali do 11 sati, ali se nismo mogli pošteno narazgovarati, jer su Obrovčani, bezobrazni kako ih je Bog dao, naslućujući da će doći sjatili se ka na ćabu.

Dakle prelistao sam Mag[azin] i meni se ne čini loš. Ima vrlo dobrih stvari na pr. onaj prvi rad Marčićev, tvoj članak o Koroliji, Baljkov nekrolog. Apsolutno slabih nema. Najgora mi se čini ona Perićkina kompilacija a mogli su izostati i Marčić II i moj fatalni Kuridža, koji će me na koncu napraviti smiješnim pred cijelim svijetom. Ali za to me nije briga perchè mi me go in eulo a mi stesso! Ljubavca je bilo nemoguće prirediti za štampu, jer to traži najmanje 4 mjeseca rada i suradnju ljudi sa terena, od kojih ti 99\% uopće ne odgovara na zamolnice (fra i altri i pop Mirko!). Stojana neću moći napisati dok ne odem lično u Mletke a to znači nikada. Po materijalu koji imam ispao bi samo jedan torzo, vrlo krnj i nereljefan: ili ću dati nešto što doista vrijedi, nešto živo, plastično, istinito ili nek se stara potomstvo t.j. ti, ili Braco ili Uroš II.

(...)

Ja ću nastojati da $\mathrm{u}(. .$.$) tim što više budem mogao primjeraka, ali se bojim da obzirom na pod-$ vojenost rezultat neće biti ko lanjski.

Ako ikako možeš da prežališ trošak, molim te puno da dogješ sa Ksenijom amo k nama da provedeš odmor. Učinićeš nam svima veliko zadovoljstvo i radost. Ajde, dragi moj, učini to svom barbi!

Ljubimo Vas svi.

Barba

$\overline{149}$ OOVD, kut. Prepiska do 1945. I. 